Florida International University FIU Digital Commons

$11-8-2012$

\title{
Mundos Prohibidos: El Poder en el Discurso Epistolar de Gertrudis Gómez de Avellaneda y Juana Borrero
}

Cointa G. Martin

Florida International University, cmart002@fiu.edu

DOI: $10.25148 /$ etd.FI12120703

Follow this and additional works at: https://digitalcommons.fiu.edu/etd

\section{Recommended Citation}

Martin, Cointa G., "Mundos Prohibidos: El Poder en el Discurso Epistolar de Gertrudis Gómez de Avellaneda y Juana Borrero" (2012). FIU Electronic Theses and Dissertations. 795.

https://digitalcommons.fiu.edu/etd/795 


\section{FLORIDA INTERNATIONAL UNIVERSITY}

Miami, Florida

MUNDOS PROHIBIDOS: EL PODER EN EL DISCURSO EPISTOLAR DE GERTRUDIS GÓMEZ DE AVELLANEDA Y JUANA BORRERO

A dissertation submitted in partial satisfaction of the requirements for the degree of DOCTOR OF PHILOSOPHY

in

SPANISH

by

Cointa G. Martin 
To: Dean Kenneth G. Furton

College of Arts and Sciences

This dissertation, written by Cointa G. Martin, and entitled Mundos prohibidos: el poder en el discurso epistolar de Gertrudis Gómez de Avellaneda y Juana Borrero, having been approved in respect to style and intellectual content, is referred to you for judgment.

We have read this dissertation and recommend that it be approved.

$\begin{array}{r}\hline \text { Juan Torres-Pou } \\ \hline \text { Santiago Juan-Navarro } \\ \hline \text { Aurora Morcillo } \\ \hline \text { Erik Camayd-Freixas, Major Professor }\end{array}$

Date of Defense: November $8^{\text {th }}, 2012$

The dissertation of Cointa G. Martin is approved.

\begin{tabular}{r} 
Dean Kenneth G. Furton \\
College of Arts and Sciences \\
\hline Dean Lakshmi N. Reddi \\
University Graduate School
\end{tabular}

Florida International University, 2012 


\section{DEDICATORIA}

A mi esposo, por no dejarme desfallecer 


\section{AGRADECIMIENTOS}

Deseo agradecer a los miembros del comité por sus valiosos aportes y consejos en la composición de esta tesis doctoral: al Dr. Juan Torres-Pou por su acertada crítica y guía, sus minuciosas lecturas y revisiones, y su anuencia a responder con prontitud; al Dr. Santiago Juan-Navarro por ofrecer soluciones simples a los temas más complejos; a la Dra. Aurora Morcillo por su disponibilidad desde el inicio de esta empresa y a mi director, el Dr. Erik Camayd-Freixas, por hacerme reflexionar sobre la seriedad de comprometerme con un tema, avalando desde el comienzo todas sus implicaciones.

Además, agradezco a mi esposo y a mis amigos, siempre allí, siempre dispuestos. Y a Dios. Él sólo sabe por qué. 


\begin{abstract}
OF THE DISSERTATION
MUNDOS PROHIBIDOS: EL PODER EN EL DISCURSO EPISTOLAR DE

GERTRUDIS GÓMEZ DE AVELLANEDA Y JUANA BORRERO
\end{abstract}

by

Cointa G. Martin

Florida International University, 2012

Miami, Florida

\title{
Professor Erik Camayd-Freixas, Major Professor
}

This dissertation analyses, through a theoretical framework and a critical approach, letters of Cuban writers Gertrudis Gómez de Avellaneda and Juana Borrero. While love letters have captured the interest of some scholars, such as Claudio Guillén, Cintio Vitier and Alexander Roselló Selimov, the conflict that the analysis of non-literary texts poses has prevented further research in this field. Therefore, I propose a systematic method of analysis encompassing but not limited to evaluating letters based on their purpose, intent, interpretation, and temporal and spatial composition; analyzing the perspective and function of epistolary entities, and examining the textual signs that distinguish the epistolary forms from the literary forms. With this analytical tool, I examine a selection of letters of Gómez de Avellaneda and demonstrate that the writer displaces her identify from the autobiographic self to the epistolary self, in order to manipulate the perspective of her addressee. Caught between the Neoclassical way of thinking and the Romantic aesthetics, her assertive discourse, also reflected in her epistolary work, contributed to the incursion of women writers into the social and professional life of the nineteen century. 
Following the same method of investigation, an analysis of letters written by Borrero proves that, by building a world of delusion, hallucination and fantasy the writer brings to prose what first generation of female modernistas had done in poetry. In both cases, my focus is on the strategies that turn these letters into instruments of power, process that transformed the love-letter paradigm and forever renovated the women epistolary genre.

This dissertation further explores the possibility of initiating a cycle in the study of personal letters to uncover a forgotten genre, mission that might build a bridge to embrace the new forms of written communication that scholars have already begun to explore in contemporary literature. 
I. LOS EPISTOLARIOS DE GERTRUDIS GÓMEZ DE AVELLANEDA Y DE JUANA BORRERO EN LA FORMACIÓN DEL SUJETO FEMENINO.

La carta y la mujer a través de la historia

Un despertar ideológico en la carrera hacia la individualidad: la carta y la mujer

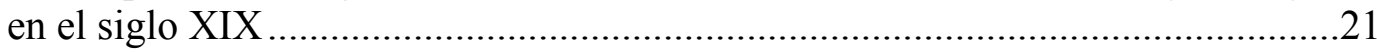

La carta de amor y el ejercicio de poder: características y funciones de la escritura epistolar.

Los epistolarios de amor de Avellaneda y Borrero: la persuasión como arte.........39

II. EL EPISTOLARIO DE AVELLANEDA: EL PODER DE LA PERSUASIÓN

Avellaneda a la vanguardia de una época

Avellaneda frente a sí misma: mito lírico de identidad

Avellaneda frente a la sociedad: organización y desarrollo de las ideas como mecanismo de persuasión

Avellaneda frente al amor: el discurso del sujeto romántico ..................................76

Avellaneda frente a la pasión y el deseo: el discurso de la mujer emancipada .....86

III. EL EPISTOLARIO DE BORRERO: EL PODER DE LA INTIMIDACIÓN

Borrero, figura de transición entre dos estilos literarios

Realidades virtuales en el arte de la persuasión: la escritura como paisaje ..........106

Religiosidad decadente como materialización de las emociones: sensualidad mística en el epistolario de Borrero

Innovación narrativa de la escritura de mujer: el epistolario de Borrero y la literatura fantástica

CONCLUSIONES

BIBLIOGRAFÍA

VITA 


\section{Introducción.}

Los críticos contemporáneos coinciden en que la presencia de la mujer en la literatura del siglo XIX marcó un hito en la ruptura con los códigos culturales, sociales y literarios que prescribían su papel como individuo (Prado 16). Se integraba así con un modelo comunicativo que contrastaba con el patrón literario paradigmático, en donde tradicionalmente el sujeto masculino (activo) se dirigía a un objeto femenino (pasivo), o en donde el discurso patriarcal se apropiaba de su voz. Tal jerarquía textual fijaba el ideal social y cultural para la mujer, pero no tomaba en cuenta que su papel como humano era más trascendental. La mujer, sin embargo, se incorporaba a la literatura con cautela. Cuando el siglo XIX despertó a la realidad de que la mujer podía escribir y publicar, ésta ya contaba con una larga trayectoria de escritura secreta, sólo salpicada aquí y allá por la escritura excepcional de mujeres que también fueron excepcionales. ${ }^{1}$ Epistolarios, diarios y autobiografías habrán de esclarecer la historia de la literatura femenina durante este momento histórico (Prado 16).

Dos mujeres que revolucionaron el arte epistolar del siglo XIX son las escritoras cubanas Gertrudis Gómez de Avellaneda (1814-1873) y de Juana Borrero (1877-1896). Sus cartas transcienden la función comunicativa, así como luego la función histórica y la biográfica. Sus epístolas cuestionan desde la escritura posturas sociales, políticas y prejuicios, además de que trastornan el discurso patriarcal que la mujer había asimilado. La carta en Avellaneda y Borrero es un acto emancipador con el que se insertan en la temporalidad de dos escenarios paralelos. Su misión explícita e inmediata era la del tema

\footnotetext{
1 Tales fueron los casos de Sor Juana, Santa Teresa y otras escritoras que escribieron al amparo de las instituciones hegemónicas.
} 
amoroso, pero la implícita y trascendental (desde la consciencia o la inconsciencia), era la de la construcción del sujeto desde la marginalización. Este proyecto doble implicaba una tarea de persuasión a partir de fórmulas y estrategias de escritura. Así para ambas mujeres, la carta se convertía en un ejercicio literario.

La carta personal siempre ha despertado el interés del público lector. No obstante, ha quedado sin contestar la pregunta de que como género, "por qué queda tan marginado de los estudios literarios?" (Bastons i Vivanco 238). Esa pregunta surge a pesar de que existen estudios en torno a este tema, en los que, por lo general, se trata la carta desde una perspectiva teórica. Los prólogos que acompañan la publicación de epistolarios los observan como unidad textual, y con frecuencia se aproximan a ellos desde una perspectiva histórica o biográfica. Sin embargo, aunque el interés por el género no ha disminuido, la carta personal no ha sido objeto de un análisis crítico más exhaustivo.

El estudio que aquí propongo es, con un enfoque teórico y práctico, someter cartas de las poetas que me ocupan a un análisis de aproximación literaria, estudiándolas como textos independientes de sus respectivos epistolarios. El propósito primario del análisis es demostrar que la carta amorosa en Avellaneda y en Borrero es un instrumento de persuasión y poder de doble cometido: la conquista amorosa y la consolidación del sujeto marginado. Como medio de persuasión, sus cartas se valen de estrategias de escritura que le dan la calidad literaria que se percibe con imprecisión desde el conjunto epistolar. El discurso amoroso de estas dos poetas se inscribe en la tradición epistolar como ruptura y continuidad de la escritura femenina. De manera que este estudio intenta además recuperar la voz de mujer atrapada en un medio que hoy ha perdido su vigencia. 
Una lectura de aproximación literaria a los epistolarios de Avellaneda y Borrero es una empresa necesaria. Por ejemplo, la reputación literaria que alcanzó Gómez de Avellaneda trascendió el reconocimiento de su suelo natal, y la situó en el círculo de los más prestigiosos escritores de la Península: "una jerarquía superior en nuestro idioma" (Remos 112). Esta escritora encarna el papel de la escritora decimonónica, quien por primera vez aspira a su independencia social y profesional, y cuya pretensión despertó sospechas en ciertos sectores de la sociedad española (Prado 23). En 1907, con la publicación póstuma de su primer epistolario, los que comenzaron a reconocer su obra epistolar se sumaron a los que ya admiraban su obra pública: Avellaneda escribía cartas usando ambiciosas fórmulas literarias.

Juana Borrero, por otra parte, se convirtió en una leyenda durante su breve vida. No es de extrañar que el círculo intelectual y literario de su época reconociera en ella a "la niña musa" y "la niña maga" ( $E$ I 200). Con su muerte en el exilio a la edad de dieciocho años, y por su negativa a publicar muchos de sus versos, Borrero dejó una exigua obra lírica. Pero la publicación de los dos tomos de su epistolario, transcritos y publicados por Cintio Vitier en 1966 y 1967, provocaron un giro sorprendente en la percepción de Borrero como la "niña maga" de la literatura cubana. Sin embargo, dista mucho aún de que sus cartas sean percibidas como parte integral de su obra literaria.

Tanto Avellaneda como Borrero se apropian del género epistolar con la pasión arrolladora del afán innovador. Uno de sus más logrados aciertos es que subvierten el papel tradicional de la mujer en la correspondencia amorosa, al asumir el papel del bardo y transformar a sus hombres en la musa inspiradora. No obstante, aquel interlocutor era parte de la conciencia hegemónica, y manifestarse como sujeto y como artista ante su 
mirada escrutadora requería el desarrollo de un proyecto de persuasión: Avellaneda colocaba el sentimiento sobre las convenciones sociales, y Borrero hablaba de amor cuando debía hablar de guerra. Aunque separadas en el tiempo y la distancia, ambas mujeres compartían en sus cartas un mismo eje temático: el amor como derecho.

Ciertamente, el género epistolar ha sido poco trabajado por la crítica desde el siglo XVIII. Dentro de esa carencia, Claudio Guillén ha hecho una investigación significativa de la epístola a lo largo de la historia, además de haber señalado, entre otras cosas, el carácter ficcional de la carta. Pedro Salinas en El defensor, aporta interesantes ideas en cuanto a la atracción de la mujer hacia el género epistolar, inclinación que observa como un "rasgo psicológico" (69). Significativa es además la antología de cartas que Francisco López Estrada publicó en 1960, en la que hacía una llamada hacia el estudio de la carta como práctica que tiende a su preservación y vigencia. ${ }^{2}$

Alexander Roselló Selimov publicó una segunda edición de los epistolarios de Gómez de Avellaneda en 1999, precedida por un informativo prólogo. Su misión era realizar una edición crítica moderna y promover "una lectura literaria" de las cartas (48). El estudio que se propuso era destacar el carácter romántico de las cartas, además de señalar el papel de Avellaneda como protagonista de la novela de su vida. Cintio Vitier, por su parte, transcribió, publicó y prologó los dos tomos del epistolario de Juana Borrero, lo que representa un notable aporte al estudio de su obra. En él destaca aspectos históricos y biográficos, su vínculo con el modernismo, y la rara capacidad creadora de esta joven escritora. Con su publicación, el crítico cubano puso en manos del lector

\footnotetext{
${ }^{2}$ Antología de Epistolas. Cartas selectas de los más autores de la Historia Universal. Madrid: Ed. Labor, 1961.
} 
moderno un legado testimonial de inestimable valor artístico y cultural. Sin embargo, al igual que Selimov, su estudio se realizó desde una perspectiva panorámica.

Con el propósito de realizar un análisis práctico de las cartas de estas dos escritoras, parto de la premisa de que es posible estudiar una carta, al igual que se estudia un poema o un ensayo. Sin embargo, rara vez un crítico literario contempla tal posibilidad. A pesar de que recientemente los estudios literarios se han dirigido hacia campos adyacentes a la literatura (como los estudios culturales, historiográficos, sociales y filosóficos), el análisis de la carta se percibe aún como una tarea de relevancia debatible. No existe una voluntad de aproximación literaria a la carta privada porque hay que resolver problemas técnicos y teóricos antes de plantearse la posibilidad del estudio.

A partir del siglo XVIII dejaron de circular los manuales teóricos sobre la epístola y "dada esta carencia, el investigador tiene que moverse en lucubraciones teóricas apoyadas en la escasa bibliografía y lanzar ideas que exigen, desde luego, una profundización ulterior o, en otro aspecto, replanteamientos críticos" (Bastons i Vivanco 235). Uno de esos replanteamientos críticos surge a propósito del poliformismo de la carta. El formato de una carta da cabida a la mezcla de géneros, y optar "por un género y cultivarlo es elegir la literatura" (Guillén, "El pacto" 76, 82). Por ejemplo, en la Carta 46 de Borrero aparecen unos rondeles, y aunque escribir rondeles es ya decidirse por la literatura, un análisis de la carta que los contiene atendería además a su función interna y al impacto de ese lenguaje en el emisor mismo (función emotiva), en el mensaje (función poética) y en el receptor (función conativa).

Surgen además preguntas sobre la relevancia del estudio de la carta con respecto a la intención del escritor al momento de la escritura, su aparente falta de compromiso con 
el arte. Claudio Guillén ha explicado, sin embargo, que la propiedad inherente del lenguaje hacia la expansión es una fuerza irreductible que tiende hacia la literatura, una especie de sino que algunos escritores han sido incapaces de resistir ("El pacto" 82). Esa tendencia supera la adscripción a los géneros y rebasa la intención del escritor, dando paso a la ficcionalidad, que es el carácter imaginario del lenguaje. Por ejemplo, Borrero se proponía relatar un sueño en su Carta 104, cuando la imaginación y la expansión del lenguaje le impartieron a su misiva un carácter ajeno e innovador. El escritor de una carta quizás se sorprenda con el resultado final de su propia escritura, tal como lo expresa Avellaneda: "[cartas], aunque sean como ésta, que lleva visos de ser una cosa estupenda" (Avellaneda 145).

La carta privada plantea además el tema de la interpretación, ya que el lector moderno no cuenta con la complicidad del escritor en la búsqueda de significados. El tercer lector de una carta no es co-partícipe con el autor, ni se establece con él un juego o compromiso de interpretación. El pacto epistolar entre emisor y destinatario no supone su presencia, por lo tanto no existe ese lugar de encuentro en el que escritor y lector se entregan a un juego de significados. En este estudio, el mensaje explícito se contempla como una situación que propone el escritor, un punto de partida del que emanan estrategias de escritura, cuya función apunta hacia un fin a veces no anticipado.

Un desafío adicional al estudio de la carta surge en relación a la noción del tiempo. Así, el presente del escritor siempre será el futuro del lector, mientras que el presente del lector representa invariablemente el pasado del escritor. Añado además las preguntas sobre dónde y cuándo tiene lugar la carta, dónde está el sujeto y cuál es el tiempo real de la carta; dónde se ubica la plenitud de su realización, ¿al momento de su 
escritura o de su lectura? Más importante aún, ¿es el pretexto de la escritura un fin en sí mismo? Con la carta se intenta la sincronización temporal con el interlocutor, lo que a veces se convierte en una virtual sincronización espacial. La carta de amor en Borrero y Avellaneda transforma esas limitaciones epistolares en pretextos de escritura, es decir, posibilidades temáticas en la creación artística.

Finalmente, lo anterior nos lleva a cuestionar la definición de la carta como un diálogo de ausentes. Sin embargo, esa definición ha contribuido al desarrollo de un mito que tiende a minimizar su valor literario, o en última instancia, a reducirla en percepción al carácter transitorio e inestable del lenguaje hablado. Como vimos, aunque el escritor desee compartir un sentimiento inmediato, el receptor jamás podría ser partícipe de ese momento único. Al tiempo de leerse la carta, el fenómeno circunstancial quizás haya desaparecido y junto con él, el sentimiento que lo inspiró. Cuando una carta logra suplantar al diálogo es porque su escritor es capaz de sustituir la realidad inmediata con una nueva, lo que equivale a crear la ilusión de ambas presencias. Estas estrategias se tornan aún más complejas cuando se establece un diálogo en medio de circunstancias no vividas, experiencias que sólo existen en la imaginación de quien escribe. Más que un diálogo de ausentes, la carta es la suma de las estrategias que el escritor usa para satisfacer la necesidad afectiva que le une a su interlocutor. De ahí su carácter literario.

Además de los problemas teóricos que surgen en torno al estudio de la carta, existen también los problemas técnicos, tales como su localización, conservación y difusión. El problema del estudio de los epistolarios comienza con su disponibilidad física, en donde la naturaleza privada convierte la tarea del compilador en una labor detectivesca. Cintio Vitier explica lo siguiente en el prólogo al Epistolario de Borrero: 
"la simple copia de estas cartas plantea, no los problemas de la transcripción sino los de la traducción: es decir, problemas insolubles" (8). Esta empresa culminó con la única edición de ambos tomos del epistolario, publicación de muy difícil acceso hoy. Otros epistolarios con menos suerte desaparecieron, cuando su postrer custodio no estimó su valor.

En el estudio de la carta, existe además el tema de la selección de material específico dentro del universo epistolar. Por ejemplo, algunos críticos han encontrado una labor monótona y repetitiva la lectura de las 900 páginas del epistolario de Borrero. Es cierto que el epistolario es un cuerpo de cartas y billetes que intercambiaron dos individuos para comunicarse mensajes personales. Aunque algunos de esos mensajes resultan irrelevantes a un tercer lector, gran parte de la correspondencia de Avellaneda y de Borrero se distingue por un indiscutible valor artístico que habría que localizar. A veces ocurre que textos completos aparecen como cartas dentro de otras cartas, lo que requiere un criterio de selección a partir de marcas contextualizadoras. Por ejemplo, la Carta III del primer epistolario de Avellaneda, "A la una de la noche", interrumpe el relato autobiográfico, para presentar un tema que desarrolla de principio a fin. Esta sección, como parte de la carta total, no representa una digresión dentro del texto, sino que surge como una unidad temática y estilística que resulta ser completa e independiente.

Una última observación que combina problemas tanto teóricos como técnicos se presenta cuando el transcriptor decide si debe corregir o no el manuscrito, evitando así la ambigüedad del texto. Vitier explica haber respetado la integridad de las cartas de Borrero, y no haberse tomado la libertad de suplir la puntuación en donde el "delirio de 
la pasión no quiso o no atinó a ponerla" (9). Aunque en algunos casos vemos en las omisiones de puntuación el impromptu pasional que explica Vitier, a veces encontramos un patrón recurrente, con lo que nos planteamos la posibilidad de una voluntad estilística.

La carta de amor en Avellaneda y Borrero se apoya sobre dos ejes que se interceptan: el deseo y el poder. Manifestándose simultáneamente a dos niveles de escritura, comunicar y persuadir, las distintas voces que convergen en el texto intentan moldear la voluntad del interlocutor. El interlocutor, por su parte, se deja seducir por una entidad a quien ha llegado a reconocer y aceptar, lo que hace que la carta de amor en estas mujeres sea también parte de un proceso de elaboración de imagen y autoconfirmación.

Conforme al propósito de este estudio, en el primer capítulo abordamos la carta partiendo de sus elementos y estructura, su lugar en la historia y la cultura, su contribución a la formación del sujeto femenino, y su papel en la incorporación de la mujer a la literatura. En el segundo capítulo analizamos un grupo de cartas de Gertrudis Gómez de Avellaneda, con el propósito de demostrar que el proceso de persuasión amorosa va aunado a una ruptura con los modelos de escritura epistolar femenina, postura que adopta para pronunciarse desde la toma de consciencia. Sobre la representación de la mujer en la escritura, Susan Stanford Friedman apunta: "Writing the self shatters the cultural hall of mirrors and breaks the silence imposed by male speech" (en Benstock 40). Fruto del período literario que transita de la Ilustración hacia el Romanticismo, Avellaneda habla del amor acogiéndose a estructuras y procesos de reflexión que favorecen el desarrollo lógico de las ideas. 
En el capítulo tercero de este ensayo analizamos las cartas de Borrero, textos en los que las estrategias de escritura funcionan como instrumento de intimidación a partir de esquemas organizados intuitivamente. Como escritora que busca su lugar dentro del modernismo en medio del sino romántico, habla en Borrero "la voz del sujeto de fin de siècle, la del artista atormentado y aislado, víctima de las incertidumbres del mundo moderno" (Schulman, El proyecto 180). En el capítulo final se sintetizan los aspectos de la problemática de este estudio, con lo que se intenta dar respuesta a la pregunta implícita de por qué se ha marginado a la carta personal de los estudios literarios. Además de las investigaciones de Michael Foucault en relación al ejercicio del poder, y aplicándolas a las relaciones interpersonales, este análisis se complementa con diversos aspectos de las teorías feministas.

Retomar el estudio de la carta personal a través de los epistolarios de Avellaneda y Borrero es adentrarse en un campo de investigación no frecuentado. Pero un análisis práctico de cartas específicas arroja luz sobre el quehacer social, cultural y literario de las escritoras del siglo XIX. Asimismo, se deriva el beneficio de ponernos en contacto con una forma de comunicación ennoblecedora que hoy se ha perdido. No pasará mucho tiempo antes que los nuevos medios de comunicación de la tecnología moderna acaparen el interés académico. De hecho, ya existen congresos mediáticos y se escriben artículos que contemplan la posibilidad del correo electrónico como un nuevo género epistolar (Marín Abeytua 746). De manera que esta disertación intenta además promover estudios que vinculen la tradición epistolar con las formas de intercambio personal que ya se incorporan a la literatura contemporánea. 


\section{CAPITULO I}

\section{Los epistolarios de Gertrudis Gómez de Avellaneda y de Juana Borrero en la formación del sujeto femenino.}

\section{La carta y la mujer a través de la historia.}

Desde muy temprano en la historia a la carta personal se la asoció con la literatura. Fueron los griegos los que acuñaron el término "epistolografía", como la actividad literaria que se ocupa de los textos en los que se usa el formato de la carta. Un tratado griego de los siglos IV y VI da la siguiente definición: "La carta es una conversación por escrito entre dos personas separadas y que satisface una determinada necesidad; en ella se dice lo que uno diría si estuviera en presencia de la otra persona" (en Muñoz-Martín 52). Su estructura se reduce a emisor-mensaje-receptor, y las partes que la componen son fecha, saludo, mensaje y despedida. En la carta clásica se identificaban además salutatio, captatio benevolentiae, narratio, petitio y conclusio. Se alistan 21 tipos de cartas en los tratados antiguos, entre los que figura la carta de amistad, de amores y de introducción, lo que conocemos como "proemios". Por el gran interés que la carta despierta, los hombres se han dedicado a coleccionarlas, agrupándolas en epistolarios.

El vocablo "carta" proviene del latín charta, que literalmente significa papel u hoja de escribir; littera o letra del alfabeto, dio origen a las palabras "lettre" y "letter"; y missus, es el término que designa un mensaje escrito que se envía, "misiva". La palabra latina correspondere, que dio origen a la palabra castellana "correspondencia", señala su carácter de intercambio y reciprocidad, de co-responder. Entre las culturas del Antiguo Oriente circulaba la carta con fines políticos, diplomáticos y comerciales, las cuales fueron difundidas por Heródoto. Pero los griegos vieron además en la carta un sustituto 
del discurso hablado, y en los tratados de retórica de la carta, de los siglos III y II a.E.C., ya se define ésta como la mitad de un diálogo que se envía a manera de regalo. De gran importancia histórica y filosófica son las cartas de Platón (primeras muestras del género literario epistolográfico entre los griegos) y las de Aristóteles.

Con Séneca se reconoce la importancia del interlocutor, y "Lucilio" llegó a ser la entidad tal vez ficticia que le sirvió para desarrollar sus ideas. Aunque casi no hay fuentes latinas sobre la teoría epistolar, sí se han conservado, por ejemplo, las cartas de Cicerón (I a. E.C.) que causaron una profunda impresión en Petrarca. ${ }^{3}$ Sus cartas plantean por primera vez "la cuestión del carácter literario de la carta en los latinos", y destacan la función de la carta como diálogo con el ausente (Muñoz-Martín 70). Existen las cartas poéticas de Horacio "A los Pisones”, Ars Poetica, así como también las cartas amorosas de Ovidio, o Heroidas, colección de 18 cartas ficticias de mujeres mitológicas, con la excepción de $\mathrm{Safo}^{4}$ La carta también jugó un importante papel en la comunicación de los cristianos del primer siglo, y la Biblia las recoge como guía espiritual para las recién formadas congregaciones cristianas.

Debido al impulso económico que tuvo lugar durante la Baja Edad Media, se fijaron los rígidos moldes de la carta tomados de la retórica. Fue así como la carta familiar clásica perdió su atractiva sencillez. Pero la destreza epistolar que se desarrolló durante este período sirvió a la cultura occidental en el intercambio de las ideas que precedieron al Humanismo. De especial interés en el arte medieval es el epistolario

\footnotetext{
${ }^{3}$ Petrarca escribía a hombres famosos ya fallecidos, según decía, para no sentirse tan solo. Luego de leer las cartas de Cicerón, le escribe: "conozco por fin quién eres ante ti mismo" (en Martín Baños 151).

${ }^{4}$ La angustia por la ausencia del amado ("canción de amigo") fue tema recurrente en la literatura lírica galaico-portuguesa entre los siglos XII y XIV.
} 
amoroso de Pedro Abelardo y Eloísa, del siglo XII. El doble discurso de Eloísa, que se presenta con humilde actitud pía, a veces esconde el deseo de su "immoderato amore" (en Cherewatuk and Wiethaus 66). Como se percibe en las cartas de Eloísa, algunas mujeres lograban obtener una educación superior.

Por lo general, las familias pudientes educaban a sus hijas con la ayuda de preceptores, como se muestra en Memorias de Leonor López de Córdoba (1363-1412), primera autobiografía conocida en lengua castellana en voz de mujer. ${ }^{5}$ La mujer se convirtió en una ávida lectora, y sus nexos con la literatura han estado fuertemente relacionados a través de la historia: "la vinculación de la mujer a la literatura viene de muy lejos y el acto de escribir no es sino la respuesta o prolongación de un acto que le precede, la lectura" (Caballé, 8, 9). La literatura da testimonio de que algunas mujeres sabían leer y redactar cartas, como lo narra el Libro de buen amor de Juan Ruiz, Arcipreste de Hita. Así la lectura llegó a ser el pasatiempo preferido de la mujer en sus largas horas de la vida del hogar durante el siglo XIV en las sociedades europeas, como aparece en El Decameron: "Ilustres damas, para recreo de las cuales emprendí la tarea de tan dilatado trabajo,[...]" (Boccaccio 373).

La literatura epistolar que se escribió durante la era medieval iba principalmente dirigida al público femenino. Se observa un interés general por este género, por ejemplo, en las muchas ediciones y traducciones que se hicieron de Cárcel de amor (1492) de Diego de San Pedro, novela sentimental que usa la carta como estrategia narrativa. La cualidad del lenguaje de expandirse a formas ficcionales explica en parte el origen de la

\footnotetext{
${ }^{5}$ Ver Biografia de mujeres andaluzas. Blas Sánchez Dueñas. Universidad de Córdoba http://www.andalucia.cc/viva/mujer/aavcordo.html\#Leonor.
} 
novela epistolar a partir de la carta de amor, y de ahí que en la historia de la literatura se entremezquen cartas reales y ficticias (Beltrán Almería 246). Este hecho sitúa a la carta de amor "a medio camino entre su existencia extra-literaria y su desarrollo en el mundo ficcional" (Cortijo-Ocaña 71).

Con el Renacimiento, la carta familiar retoma su sencillez clásica, recupera su oralidad al disminuir su rigidez retórica, y se adapta a las lenguas vernáculas: "vuelve a su espacio clásico, pero gracias a la herencia medieval no será ya nunca un género ‘marginal'... la epístola sigue ocupando un lugar prominente" (Martín Baños 151). La carta cobra una importancia fundamental en el intercambio de ideas entre los humanistas. Por ejemplo, existe la amplia correspondencia de Erasmo, además de las Epistolas familiares (1530) de Fray Antonio de Guevara, algunas de ellas cartas ficticias, y precursoras del ensayo. ${ }^{6}$ El espíritu del Renacimiento propició también las digresiones de carácter subjetivo en la carta familiar: "Creo que así como la naturaleza ha hecho a los hombres diversos rostros, también les ha dado diversos ingenios y diversa fantasía" (Maquiavelo 71). Durante este período de renacer cultural y artístico, la escritura de epistolarios sirvió para dar a la mujer cierto protagonismo literario. Así aparece el Epistolario (1500) de Catalina de Siena, el cual se coloca en la lista de modelos estilísticos que sirvieron en el desarrollo de la lengua italiana (Cherewatuk and Wiethaus 89). Más tarde, Juan de Segura suple la voz femenina en Processo de cartas de amores (1548), primera novela epistolar escrita en Europa.

\footnotetext{
${ }^{6}$ Obsérvese este pasaje de una carta de Erasmo a Juan de Valdés: "Por lo mismo que aprecias en tanto estas mis cartas, escritas con tanto descuido, que no dudas en colocarlas entre las principales joyas, también yo, ... antes más bien le conservaré guardado en el archivo de mi pecho" (Baselea, 21 de marzo de 1529).
} 
La educación de la mujer cobró un nuevo impulso durante el Renacimiento. Erasmo recomendó su educación, y su amigo, Luis Vives, escribió al respecto el tratado Institutione de feminae christianae (1529). En España, por ejemplo, se comenzó a dar acceso a las hijas de nobles, letrados y burgueses en la Universidad de Salamanca. Pero además de su educación, la avidez por la lectura capacitó a ciertas mujeres para emprender proyectos literarios. Tal es el caso de Santa Teresa de Ávila (1515-1582), ávida lectora de romances y de libros de caballería. Una muestra de la educación de la mujer renacentista se encuentra en las cartas de la célebre cortesana italiana, Verónica Franco. La publicación autorizada de sus cartas, en 1580, le sirvió para establecer sus credenciales sociales e intelectuales en la corte renacentista italiana (Franco 43).

Con la llegada del europeo a América comienza una nueva etapa de trasiego epistolar. Muchas de estas cartas son las crónicas que hoy consideramos como las primeras manifestaciones literarias desde el Nuevo Mundo. Por medio de ellas el hombre europeo supo de una sociedad utópica en donde creyó habitaba el hombre en su estado natural. Desde Cuba se escribieron cartas con las que los primeros colonizadores dieron cuenta de la realidad en la Isla. Narrando a través de micro-informes, estas misivas son crónicas escritas desde la perspectiva doméstica: la retórica epistolar comenzaba a describir el entorno criollo (Ver Otte 569-571).

De manera general, las mujeres apenas tuvieron voz pública. Un caso excepcional fue el de Catalina de Erauso, la Monja Alférez. Aunque no fue la única mujer que llegó al Nuevo Mundo vestida de hombre, su autobiografía "se erige como uno de los máximos ejemplos de la transgresividad en su época, pues la autobiografía había llegado a ser un instrumento para consolidar el discurso de poder de los hombres" 
(Esteban 56). Su relato demuestra que la Monja no encuentra otro medio de evadir su situación opresiva, por eso recurre a reafirmar los "valores en los que el patriarcado ha basado su ideología sobre la supremacía masculina" (Gómez 5). Sor Juana Inés de la Cruz sufrió las consecuencias de articular una voz pública, tanto como mujer como religiosa. Su carta autobiográfica (Respuesta a Sor Filotea de la Cruz, 1691) denuncia el recio control de las instituciones hegemónicas al desarrollo intelectual de la mujer.

El entusiasmo renacentista por la educación disminuye durante el siglo XVII. Esto repercute en la percepción del papel de la mujer en la sociedad, situación lastimosa reflejada en el teatro barroco español, en donde el personaje femenino se enfrenta a un entorno que sistemáticamente sospecha de su honor y de su honra. Paralelamente a esta situación social, el siglo XVII vio el nacimiento de la literatura epistolar (Grassi 23). El género epistolar era considerado en la misma categoría literaria de los grandes géneros: "la carta personal fue una forma de arte, como lo fue el sermón, [...]" (Wellek 30). Durante el siglo XVII la carta real y la ficticia intercambiaban modelos de escritura, y es también durante este siglo que se efectúan publicaciones no autorizadas de cartas escritas por mujer.

La apropiación y publicación de cartas de mujeres tenía serias consecuencias para su reputación, así como se ilustra en La Princesse de Clèves, de Marie-Madeleine de Lafayette (1678). ${ }^{7}$ No obstante, el interés del público por leer sucesos escandalosos reales o ficticios dio lugar a esa práctica. Otros escritores se ocuparon de escribir cartas de amor apropiándose de la voz de mujer, "to experiment safely with narrative fiction at a

\footnotetext{
${ }^{7}$ Ver Cherewatuk and Wiethaus, 10-15 acerca de la manipulación de cartas a manos de compiladores y editores.
} 
time when the novel was considered an illegitimate genre and when models of 'masculine' writing were rigidly defined by classical rhetoric" (Jensen 5). Hasta el siglo XVII la novela era considerada de reputación dudosa, pero el auge de la novela epistolar ocurre durante el siglo XVIII, ya que el Neoclasicismo recupera las formas literarias clásicas, entre ellas, la epístola.

El arte del neoclasicismo vio en la carta un medio de expresión afín con la realidad, la mesura y el ejercicio didáctico. La forma epistolar propicia el monólogo reflexivo propio del ensayo moralizante. Avellaneda, por ejemplo, sentía gran admiración por Rousseau, quien no sólo fue un gran escritor de cartas, sino también fue el autor de La nueva Eloísa (1761), novela epistolar de crítica social. Veinte años después, Choderlos De Laclos publica su inmortal novela epistolar, Les liaisons dangereuses, relato escrito enteramente a base de cartas, cuyo reflejo de la sociedad era tal, que se rumoraba que las cartas eran genuinas y que además habían precipitado el estallido de la Revolución.

Durante el siglo XVIII las mujeres intelectuales de Francia dieron comienzo a la modalidad epistolar que aprendieron con la publicación de Lettres portugaises (1669). Madame de Sévigné fue una de las muchas mujeres que adoptaron el lenguaje pasional de las cartas de la monja al escribir a su hija: "what tears I shed in finding myself persuaded of that truth which of all truths I most long to believe-you can well imagine!" (en Mossiker 77). Así también, Georgiana, Duchess of Devonshire fue una asidua escritora de cartas quien, siguiendo el modelo de las misivas de Rousseau, se inspiró en escribir una novela epistolar, The Sylph (1779). Lady Melbourne, amiga de la duquesa, fue también una gran escritora de cartas. Esa inclinación femenina por la escritura epistolar 
se explica según Katharine Ann Jensen es un aspecto lingüístico de su naturaleza: "Since woman's linguistic talent was seen to be part of her nature, her linguistic power remained within the appropriate bounds of prescribed feminity" (10). Con esa modalidad femenina, ciertos editores vieron la oportunidad de publicar manuales de modelos de escritura.

La mujer intelectual europea y criolla, educada por preceptores o autodidacta se destacó por organizar tertulias y por ser anfitriona de salón, espacios en donde la conversación inteligente se consideraba una forma de arte. Cultivaron así el arte epistolar como un medio de intercambiar un diálogo inteligente. La carta llegó a ser para algunas de estas mujeres una herramienta eficaz para lograr reconocimiento o movilidad social. Madame du Deffand, otra salonnière, se sirvió del arte de escribir cartas para corregir su pasada y dudosa reputación y para obtener ascenso social. Sus billetes y cartas amorosas son de admirable elegancia. ${ }^{8}$ Gómez de Avellaneda admiraba, por ejemplo, "un genio como el de la Staël", la autora de novelas, cartas y ensayos, quien con su arte preromántico se destacó en la corte y los salones literarios parisinos (Avellaneda 99).

En 1747, las más de 2.500 cartas que escribió Françoise de Graffigny le sirvieron de modelo en la publicación de su novela epistolar, Lettres d'une Péruvienne. Su relato, inspirado en Comentarios reales de los incas del Inca Gracilaso de la Vega (traducidos al francés en 1633), desafiaba la opinión generalizada que la mujer no era capaz de reproducir la estructura y la organización de la novela, como señala Jonathan Mallison: “Women's writing was most commonly associated with, and limited to, letters,... writing

\footnotetext{
${ }^{8}$ Madame du Deffand mantenía una correspondencia significativa con Voltaire: "I write only to you in Paris, Madame, because your imagination has always accorded with my Heart; ..." (en Craveri 204).
} 
of a more critical kind largely remained the province of men" (ix). Sin embargo, su relato ilustra el papel de la carta de amor como estrategia narrativa, ya que era un mecanismo menos aventurado con el cual romper el confinamiento de la mujer a la escritura secreta. Si la escritura femenina se limitaba a la escritura epistolar, la mujer se valió de esa misma estrategia para ingresar a la literatura, como indica Jensen:

If woman's purportedly natural talent for letters located her writing in an unselfconscious emotional zone, then women's move into the letter novel defied this constraint... Women writers' move from the love-letter genre to the letter novel is not only powerfully disruptive of an ideology of femininity, it is also profoundly paradoxical. By writing novels that seem to be letters, women can appear to themselves and to their readers to be less ambitious about their writing than they, in fact are (92).

Al usar la carta como recurso narrativo, la mujer transgredía doblemente, al burlar los cánones de escritura femenina y eludir las posibles consecuencias de la crítica social. A partir del siglo XVIII, cuando el mercado se abre a la novela en el concepto moderno, fue inevitable que los personajes de la literatura ejercieran influencia en la manera de vivir de la mujer, influencia que la mujer no tardó en incorporar a su escritura.

El que a la mujer tradicionalmente se la asociara con la escritura de epistolarios amorosos se explica hoy en base al silencio impuesto a través del tiempo, a su inadecuada 
educación y a sus limitadas posibilidades de movilidad social. ${ }^{9}$ Sin embargo, algunos editores e intelectuales vieron en la profusión de sus cartas de amor una amenaza. De manera que juzgaron esa tendencia como una característica femenina, atando por definición a la mujer al cultivo de un género que no ponía en peligro la hegemonía masculina en la literatura (Jensen 2, 5). Limitada a escribir textos de limitada o ninguna circulación, se alejaba a la mujer del poder que confería la literatura.

De esa manera persuadida, a la mujer se le suministró suficiente material didáctico en la forma de modelos que fomentaban la escritura de cartas. Samuel Richardson concibió su novela Pamela (1740) al comenzar a escribir modelos de cartas, Letters Written to and for Particular Friends, on the Most Important Occasions. Aún Pamela, "was originally designed as a set of letter-writting templates to be imitated or customized by semi-literate users" (Keymer xiii). En la novela, Richardson se apropia de la voz epistolar femenina, y con ello ilustra el uso de la misiva como recurso femenino para expresar sus sentimientos e inquietudes.

Limitar las oportunidades de educación obstaculizaba también el acceso de la mujer a la literatura. Durante los siglos XVIII y XIX el modelo de educación femenina se basó en el Emilio o la educación, de Jean-Jacques Rousseau, instrucción que confinaba a la mujer a las labores del hogar. Rousseau no creía en la capacidad femenina para la educación, y hasta retó la autoría de las cartas de la monja portuguesa (1668), porque las mujeres eran "incapaces de escribir con genio y pasión [...]" (en Guillén, "El pacto" 95). En España y en Cuba, las oportunidades de educación para la mujer estuvieron limitadas

\footnotetext{
${ }^{9}$ El silencio como virtud de la mujer era tanto exigido como comprometedor. Recuérdese el pasaje de The Princesse de Clèves: "By her silence, Mme de Clèves showed she was willing to listen ...") (105).
} 
hasta finales del siglo XVIII, aunque las familias pudientes educaban a sus hijas en la religión, la aguja, el bordado, la costura y la música.

La historia marca al siglo XVIII como el período en el que la novela surge como literatura y se comercializa como tal. Este hecho coincide con que a partir de entonces se comienzan a echar de menos los tratados teóricos sobre la escritura epistolar (Bastons i Vivanco 235). Además, con la entrada del nuevo siglo, gradualmente se abandonó el uso de ese formato como estrategia narrativa.

\section{Un despertar ideológico en la carrera hacia la individualidad: la carta y la mujer en el siglo XIX.}

En el siglo XIX concurren las ideas de la liberación en lo social, y las ansias de expresión íntima en lo particular. En el ámbito político, España se enfrenta a las guerras de las colonias en América, cuando en el suelo patrio comienza el siglo con la invasión francesa. Las ideas filosóficas volvían la mirada hacia la naturaleza y el pasado histórico, buscando las bases ideológicas para que la sensibilidad y el sentimiento desplazaran a la razón en la búsqueda ontológica. El arte recogía la problemática individual y se prestaba a la expresión del sujeto preocupado por los males sociales y agitado por el orgullo nacional. Se gestaba el romanticismo. Mientras tanto, en Cuba se avivaba el espíritu de independencia, y la recién formada conciencia nacional se fortalecía con las ideas de pensadores y educadores. Se sentía aún la influencia de la Península, como indica Juan J. Remos: "[la] literatura cubana, aunque atemperada a la naturaleza de su suelo y a sus imperativos históricos, ha de correr por los rieles del romanticismo universal" (100).

En un ambiente en donde comenzaba a valorarse la conciencia individual, el ingreso de la mujer a las filas de los escritores del siglo XIX era tan inminente como 
inevitable. Para esta coyuntura histórica y cultural comenzaban a prepararse intelectualmente las mujeres que tenían cierto grado de acceso a la educación. Sin embargo, de manera general, hasta el siglo XVIII se había logrado poco. Concepción Arenal (1820-1893) escribe al respecto: "Lo que se llama historia en la vida intelectual de la mujer es una patraña, porque no se puede hacer la historia de lo que no existe". ${ }^{10}$ Aunque comenzaban a verse los esfuerzos, la Iglesia seguía marcando las pautas en la educación de la mujer, a quien todavía limitaba su papel al cuidado del hogar y la familia.

El ideal femenino durante el siglo XIX era el del "ángel del hogar”, celosa guardiana de los valores burgueses. Toda otra curiosidad intelectual la haría sentirse traicionando su naturaleza femenina: “[...] siempre me había resistido a emplear mi tiempo en tareas que me parecían extrañas a mi sexo, sacrificando mi decidida inclinación por la literatura" (Coronado 456). La misma escritora, Carolina Coronado (1820-1911), se expresa de manera similar en otra carta de 1840: "Cuando aseguro que mi instrucción es muy limitada, no lo digo por un exceso de modestia. [...] fue un acontecimiento extraordinario el que una mujer hiciese versos, y el que los versos se pudiesen hacer sin maestro" (en Caballé 455). Caterina Albert (1869-1966), quien publicaba bajo el pseudónimo de Victor Catalá, explica las limitaciones de la educación de la mujer: "Figúrese que me enseñaron a conocer a Jesús y a hacer «palitos» y «ganchos», siendo ésta mi instrucción oficial; lo demás lo he hecho por mi cuenta" (en Caballé 216). No fue sino hasta principios del siglo XIX que se dieron los primeros esfuerzos serios por educar a la mujer. Durante la segunda parte del siglo, las facultades de filosofía y pedagogía, así como escuelas de arte, dieron también cabida a la mujer.

\footnotetext{
${ }^{10}$ La mujer del porvenir. Capítulo IV. Biblioteca Virtual Miguel de Cervantes.
} 
La literatura de la época da testimonio de lo que era la educación para la mujer en España. Por ejemplo, en Dos mujeres (1842) de Avellaneda, la educación de Luisa había sido "más religiosa que brillante", habiendo aprendido economía doméstica, pero sólo rudimentos del conocimiento seglar. Sus lecturas eran muy limitadas y la censura maternal la obligaba a leer algunas novelas a "hurtadillas" $(11,12)$. Catalina, en cambio, tenía una educación más extensa, además de ser autodidacta. La sociedad aceptaba a Luisa como el "ángel del hogar", pero se sentía incómoda con la actitud intelectual de Catalina, a quien caracterizan como "esas mujeres hombres que de todo hablan, que de todo entienden, que de nadie necesitan [...]" (73). Con el tiempo fue necesario transformar la caracterización de los personajes femeninos en las novelas, ya que por mucho tiempo se les había atribuido el hermetismo y la inexpresividad (Prado 20). La mujer debía educarse para incorporarse a la literatura, tanto como escritora como personaje de ficción.

A principios del siglo XIX se observan en Cuba los primeros esfuerzos en fundar escuelas para la educación de la mujer de familias de cierto poder económico. ${ }^{11}$ Luego, con las guerras del 1868 muchas cubanas o se unieron a sus hombres en la manigua o marcharon al exilio, y algunas de ellas se dedicaron allí a labores educativas. ${ }^{12}$ En la segunda mitad del siglo XIX, la Facultad de Filosofía y Letras, la Escuela de Farmacia, la Escuela de Leyes, la Escuela de Pedagogía, así como escuelas de pintura y conservatorios

\footnotetext{
${ }^{11}$ En 1803 se abre la escuela de las monjas Ursulinas, a la que le seguirán otras escuelas para competir con ellas.

${ }^{12}$ La abuela de Juana Borrero, Ana María de la Merced, fue una poetisa y patriota que marchó a la manigua con su hijo Esteban, padre de Juana. Allí fundó varias escuelas, en las que su hijo era maestro con sólo 11 años de edad.
} 
de música, entre otros, dieron cabida a la mujer. Muchas mujeres pobres comenzaron a cultivarse, y no son pocas las que asistieron a pequeñas escuelas rurales o de barrio.

Avellaneda, sin embargo, pertenecía a una de las familias más pudientes de la Isla, y su brillante educación comprendía literatura, lenguas, música y filosofía (Avellaneda 58). A esto hay que añadir que los esclavos domésticos realizaban las labores del hogar, por lo que "Tula" podía dedicar largas horas del día a la lectura de novelas, poesías y comedias. El mayor placer de su primera juventud era estar encerrada en el cuarto de los libros, "leyendo nuestras novelas favoritas y llorando las desgracias de aquellos héroes imaginarios, a quienes tanto queríamos" (Avellaneda 52, 53). Además, asidua al teatro y a los espectáculos, su exposición a toda manifestación artística no podía menos que acrecentar su acervo intelectual.

Por su parte, Juana Borrero fue educada en el seno de una familia cubana de poetas e intelectuales. Hija de un médico, maestro y patriota, Juana ya pintaba y versificaba desde los cinco años, y escribía su primer poema a los siete. Fue ávida lectora y autodidacta, y sabía de los mejores talentos de la época por los periódicos y las revistas. Además, las tertulias literarias que se celebraban en la casa familiar complementaron su educación. Su hermana, Dulce María, nos da un ejemplo de lo anterior: "La entrada de Casal en nuestra vida fue algo así como la entrada de un ancho rayo de luna en una estancia desierta que estuviese, en sus cuatro paredes, revestida de espejos" (en Morán ix). La vida del hogar, la exuberante naturaleza tropical, los ideales patrios y su interés autodidáctico determinaron su destino poético.

La realidad en Cuba durante el siglo XIX tendía a la comunicación. Las causas políticas, el exilio y la necesidad de intercambiar ideas, propiciaron en la Isla una gran 
actividad epistolar. Por ejemplo, existen las cartas que intercambiaron importantes intelectuales de la época, entre los que destacan José María Heredia (1803-1839), Félix Varela (1788-1853), Domingo del Monte (1804-1853), José de la Luz y Caballero (18001862) y José Antonio Saco (1797-1879). Con frecuencia, los temas de sus cartas eran la independencia política, social y cultural de la Península. Dentro de los grandes epistolarios cubanos de todo tiempo, ninguno alcanza el vuelo lírico e ideológico del de José Martí (1853-1895). ${ }^{13}$ El esteticismo del epistolario martiano y la profundidad de las ideas nos abren las puertas a una sensibilidad inédita.

Hablar del entorno intelectual decimonónico, y de la importancia de la carta en el intercambio de ideas, es también hablar de la repercusión de la prensa escrita en Hispanoamérica y en la Península durante el siglo XIX: el periódico revolucionó la sociedad y la cultura decimonónica. La prensa escrita puso en contacto a un vasto número de lectores con las ideas de la época y también con la literatura. Importantes obras literarias se conocieron primero a través del papel periódico. Muchos escritores se apropiaron del diálogo virtual en el formato epistolar para redactar sus artículos periodísticos y ensayos. Avellaneda también se desempeñaba en la escritura de ensayos, tanto para los periódicos de la Península como para los de Cuba: "Ya ve usted como debo estar muy satisfecha con el éxito tan brillante de mis ensayos literarios" (Avellaneda 123). Por otra parte, las cartas de Juana desde Cayo Hueso sobre el quehacer de la comunidad cubana en el exilio recuerdan por momentos descripciones propias del costumbrismo.

\footnotetext{
${ }^{13}$ Acerca del epistolario de Martí, Fina García Marruz escribe: ¿Dónde vimos antes, en qué literatura, en qué himnario, en qué declaración de amor, silencios y palabras, comienzos y despedidas, como estas... ¿En qué nos conciernen estas efusiones dichas a otros... como demandándonos algo que hubiéramos olvidado, o que estuvieran dirigidas directamente a cada uno de nosotros?" (Vitier 310).
} 
Dentro de la prensa escrita, la carta ficticia se convirtió en un metagénero narrativo con una función política, social y también literaria. La estructura de la misiva era la forma ideal desde donde el autor podía enmascarar una crítica a veces mordaz. La risa, la parodia, la ironía y la sátira se hacía posible en virtud del juego semiótico que se establecía entre el escritor y el lector. Este metagénero parte del modelo de las Cartas persas (1721) del barón de Montesquieu, novela epistolar de sátira política y social a la que siguen Las cartas marruecas (1789), obra póstuma de José Cadalso.

El siempre creciente grupo de lectores del periódico incorporó también a un vasto componente de la sociedad decimonónica: el sector femenino. Tras el advenimiento de la burguesía, la independencia económica y social de la mujer fue una fuerza sobrepujante en la sociedad del siglo XIX, y su importancia revolucionó la manera de hacer periodismo. Tomar el pulso de las preferencias de lecturas de la mujer determinó los reajustes que hizo la prensa para capitalizar ese importante sector de la sociedad. Por las cartas de la escritora nos enteramos acerca de otra modalidad periodística que tuvo gran aceptación durante el siglo XIX: la novela por entregas. Si el folletín había hecho accesible al público las grandes novelas de la época, la novela por entregas apeló a un gusto literario que comercializaron con gran éxito las casas de periódico. ${ }^{14}$ Muchas de estas novelas con frecuencia usaron el formato epistolar como recurso narrativo, por la capacidad de la carta de dar cabida a la mezcla de géneros.

La gran importancia cultural que tuvo el periódico en España durante el siglo XIX se hizo también evidente dentro de la sociedad cubana. Tanto Avellaneda como Borrero

\footnotetext{
${ }^{14}$ Sobre el gusto literario de la España del siglo XIX, véase La España de nuestros abuelos de Amando de Miguel. Madrid. Espasa: 1998.
} 
publicaron sus primeros versos en los periódicos de la época. Por ejemplo, El Papel periódico de La Habana (primer diario habanero que circuló entre 1790 hasta 1805) incluía la publicación de artículos de interés cultural y artístico, así como también $E l$ Diario de la Marina, que comenzó a imprimirse el primero de abril de 1844. Además, con el auge de la literatura Modernista en Latinoamérica, en Cuba proliferaron las publicaciones de revistas literarias. Este ambiente artístico y cultural de la última parte del siglo XIX recibió con beneplácito las publicaciones de La Habana Elegante, El Fígaro, La revista cubana, La Habana literaria, y Gris y azul. Las cartas de Borrero a Carlos Pío cuentan del gran número de escritores latinoamericanos que publicaron sus trabajos en las revistas cubanas, así como también de sus propias contribuciones a esas publicaciones.

La carta ficticia continuó siendo usada como recurso narrativo en la novela durante el siglo XIX, como por ejemplo, en Pepita Jiménez (1874) de Juan Valera. Pero a mediados del siglo XIX la introspección y el monólogo interior comenzaron a reemplazar la carta ficticia como expresión de realidad y veracidad (Grassi 29). Hacia el fin de siglo disminuyó el uso de la carta personal como medio de comunicación, así como también su uso como estrategia narrativa. En la novela se utilizará cada vez más el diálogo y la introspección, a la manera del diario. De esa manera, el género epistolar sufrió la pérdida de su protagonismo literario de dos maneras: como espejo de las costumbres de una época y como estrategia narrativa. ${ }^{15}$

\footnotetext{
15 “Agonía del género epistolar”. María Bertoni en Literatura Trackback. Junio 9, 2007. http://www.espectadores.worldpress.com.
} 
Tan tarde como el siglo XIX la novela todavía se observaba con recelo, hasta el grado de despertar un temor social. Se instaba a que la mujer leyera novelas como $E l$ Ángel del Hogar (1864), de Pilar Sinué. Se temía la literatura de mujer que llamara indebida atención a sus emociones, y se veía su sensualidad como la consecuencia de su vínculo secreto con la naturaleza: la mujer conocía y participaba en la misteriosa formación del ser. Así, durante el siglo XIX hispanoamericano se colocó a la mujer bajo el escrutinio de las ideas cientifistas que dieron lugar a estereotipos femeninos en la literatura: mujer-ángel o mujer-monstruo.

Las voces de la prensa y de las distintas manifestaciones artísticas durante el siglo XIX iban forjando las marcas culturales de la identidad cubana. Como parte de esa identidad, la mujer pasó a ser el símbolo de la patria y a encarnar un concepto abstracto, cuyas virtudes eran la abnegación, el sacrificio y la actitud de espera (Vallejo 971). Ese ideal mujer-patria cambiaría con un despertar a la necesidad de expresarse desde su individualidad, con identidad e inquietudes particulares. La idea romántica de la mujeremblema y las representaciones formuladas por la consciencia colectiva cambiaban a medida que se construía la República.

Mientras estas ideas y acontecimientos marcaban la historia social y política en España y en Cuba durante el siglo XIX, la carta de la mujer continuaba circulando discretamente. Muchas de sus misivas amorosas, que con frecuencia amparaban ideas sociales y políticas, cambiaban de mano a espaldas de la sociedad y de la familia. Avellaneda, por ejemplo, mantenía una correspondencia al margen de lo que llama "canallería literaria", el ambiente social y literario que prevalecía en el Madrid de la época: " ¡Cuidado, ... Tiemblo de caer en lenguas de las gentes de teatro y de imprenta" 
(Avellaneda 195). A Borrero le preocupaba perder la oportunidad de expresarse como individuo y como artista, así que intercambiaba cartas de amor a escondidas de sus padres: "Pero si descubrieran nuestra correspondencia... tiemblo de pensar lo que sucedería" ( $E$ I 100). No obstante, este elemento de complicidad en la correspondencia amorosa con frecuencia contribuía a enriquecer la composición epistolar.

La carta seguía siendo una de las estrategias preferidas de la mujer para entrar en la literatura, porque su escritura dependía de la presencia de un interlocutor para expresarse. Así, entre la realidad y la memoria idílica del paisaje nacional, aparece el diario de viajes de la Condesa de Merlín. Viaje a La Habana, publicado en francés en 1844, se compone de 36 cartas dirigidas a familiares y amigos, fieles interlocutores que facilitaron el desarrollo de su relato. La esmerada educación de la Condesa, (María de las Mercedes Beltrán Santa Cruz y Cárdenas Montalvo y O'Farrill) hizo posible la composición de un texto híbrido que satisfacía el anhelo intelectual del europeo sobre el Nuevo Mundo. Con el estilo franco y sencillo de su relato, a veces idealiza el paisaje mientras critica la costumbre. Gómez de Avellaneda, otra amante del arte epistolar, escribió la introducción que llevó la versión en español del relato de la Condesa.

Pero el que la mujer escribiera y publicara literatura no coincidía con el modelo hegemónico del ideal femenino. Aunque hubo mujeres que ligadas al poder no se les negó ese reconocimiento (como Teresa de Jesús y Sor Juana), no fue sino hasta el siglo XIX que comienza a surgir un cambio de percepción. No obstante, para conciliar la idea de la mujer que publica con la mujer idealizada por la sociedad, se "masculinizó" a 
algunas escritoras (Prado 23). ${ }^{16}$ Avellaneda fue una de las mujeres que más sufrió esa crítica, por lo que a veces se vio inclinada a publicar bajo pseudónimos masculinos. Sin embargo, las mujeres no dejaron de escribir, demostrando así su resolución de alcanzar un mayor protagonismo: "La literatura fue el espacio mental desde el cual pudieron luchar pacíficamente por su autonomía" (Caballé 12). A partir de entonces, algunas mujeres publicaron profusamente, como se comprueba por la ocupada vida profesional que Avellaneda cuenta en sus cartas.

Con la entrada de la mujer al mundo de la literatura se marca un importante paso hacia un mayor protagonismo en lo literario y también en lo social. Pero el romper con los patrones hegemónicos del ideal femenino seguía a un largo proceso de asimilación personal:

Que las mujeres escriban -bien o mal importa menos-, que lo hagan para publicar, en el siglo XIX es un paso de esta rebelión sin vuelta atrás, y así hemos de entenderlo. Con sólo este hecho dejaban de cumplir con lo que la sociedad había considerado su función desde hacía seis mil años. Coger la pluma era coger la espada,... Y escribir delataba vida inteligente. Vida pensante inexpresada durante siglos... (Prado 15, 16).

Pero la mujer no habría podido oponer una resistencia a la crítica social y familiar sin primero haber cobrado consciencia de su propia identidad. No tendría nada que aportar al mundo de las ideas si no estaba segura de su capacidad de concebirlas y expresarlas.

\footnotetext{
${ }^{16}$ Acerca de la masculinización de la mujer, Carolina Coronado (1820-1911), señala en una carta de 1845: “... hallo que puede una mujer estar escribiendo toda su vida sin renunciar a su sexo, como tantos pretenden" (en Caballé 459). Aunque otras escritoras publicaron bajo pseudónimos, tales como George Sand, Fernán Caballero y Víctor Catalá.
} 
Así la lucha por hacerse oír de manera inteligente fue un proceso gradual que la mujer habría de conquistar desde múltiples frentes.

\section{La carta de amor y el ejercicio de poder: características y funciones de la escritura} epistolar.

Hasta el siglo XIX, la mujer había llegado a ser un producto social. Simone de Beauvoir observó la tendencia de la mujer a identificarse con los patrones sociales, y advirtió su incapacidad de reconocerse como individuo con necesidades e inquietudes particulares (257). Sin embargo, llegó el tiempo en el que algunas mujeres comenzaron a cuestionar sus propias limitaciones y decidieron revisar la percepción que tenían de sí mismas.

La escritura fue uno de los medios que usó la mujer para expresarse, aunque con frecuencia había aprendido a representarse de acuerdo al modelo hegemónico. Se percibe a veces en su escritura una realidad no expresada que yace bajo la superficie, "el texto invisible" o palimpsesto que hoy advertimos en sus trabajos literarios (Zavala 29). Pero al escribir cartas, documento íntimo de circulación controlada, la mujer encontraba una dinámica diferente en lo que se refiere a la comunicación escrita. No obstante esa aparente libertad de expresión, en el estudio de esas cartas persiste el tema del sujeto: cómo ayuda la carta en el proceso de su formación y cómo éste la usa para influir en otros.

Aunque escribiendo cartas la mujer se dedicaba a tareas alejadas de la autoridad que generaba la literatura, esa actividad íntima le permitía colocarse más allá del canon y de las convenciones sociales, promovía la reflexión subjetiva y se convertía en una práctica para el desarrollo y la expresión de las ideas. Era un ejercicio intelectual que 
propiciaba el reconocimiento personal, además de una oportunidad de opinar desde una perspectiva crítica. El diálogo que presupone la carta podía transformarse en monólogo íntimo, un mecanismo con el que se maduraban las ideas al correr la pluma: "Esa gran palabra libertad, que ha tenido tantos mártires, me parece después de todo un sonido y nada más" (Avellaneda 192). Todo ese abanico de posibilidades se abría ante la mujer gracias a la estructura y características de la carta.

Como diálogo diferido que pertenece a un género primario y por sus múltiples usos y funciones, a la carta se le consideró en la misma categoría que al sermón (Wellek 30). En su redacción se imita la oralidad, y tanto la carta real como la ficticia, se presta para aconsejar, exhortar o influir en otros. De acuerdo con las intenciones didácticas que a veces lleva la carta, su escritor siempre está consciente del lenguaje como vehículo de su mensaje. El contenido de una carta es frecuentemente autorreferencial y éste se vale de sus propios códigos interpretativos. El sujeto a veces usa el espacio epistolar para hablar de sí mismo y de su entorno, de ahí que el escritor se sienta inclinado a la abstracción subjetiva y auto-reflexiva.

Aunque la carta es un poderoso documento para influir en otros, nótese, sin embargo, que esa influencia primero y ante todo afecta a quien la escribe. Su escritor es su primer lector, y el texto no tiene menos que impactarle a él antes que a cualquier otro. La manera en la que se representa y el acto de poner por escrito aquello que piensa terminan por tener un efecto sobre la percepción que tiene de sí mismo. En la literatura se ilustra tal efecto en la citada novela, Pepita Jiménez. Una vez enviada, la carta adquiere su plenitud al ser compartida, es decir, "leída y sentida" por el que la recibe (Salinas 45). Escribir cartas no es una práctica solitaria, como sí lo es la escritura de 
diarios. El que recibe una carta agrega a su función de lector una función anterior a la lectura, a medida que el escritor anticipa su reacción y determina la mejor manera de impactarle.

A la afirmación de Salinas de "escribir es cobrar conciencia de nosotros" (Salinas 36), Guillén pregunta, “Sí, ¿pero de cuál de nosotros? ¿El yo solicitado o estimulado por quién?” (“El pacto”, 83). De ahí la importancia del interlocutor como colaborador silente del proceso de escritura. Desde la perspectiva del lector moderno, el interlocutor parece funcionar como un narratario, una entidad que media entre éste y el escritor. Aunque con frecuencia sólo conocemos parcialmente las respuestas, sus reacciones van añadiendo texturas y niveles de significación al mensaje, a medida que el escritor hace referencia a ellas. Una carta de amor puede o no contener un mensaje explícito, y a veces se escribe para satisfacer una necesidad de comunicación que nunca se satisface: “Apenas vuelvo de mi paseo tomo la pluma para ti, aunque nada puedo decirte que no sepas" (Avellaneda 130). Sea que contenga un mensaje explícito o no, escribir a otros es una oportunidad de deslumbrar al lector con la escritura, una manera tácita de persuasión.

El Diccionario de retórica, crítica y terminología literario, indica: "toda comunicación va dirigida no sólo a un cambio de informaciones, sino también a ejercer una acción sobre el receptor: las miras de quien habla o escribe pueden ser de carácter pragmático,... $(70)$. Como medio de comunicación entre los individuos, la carta funciona como espacio desde donde se ejerce "cierta influencia sobre su destinatario" (Guillén, "El pacto" 82). El grado de esa influencia se manifiesta cuando lo que predomina en el discurso es la función conativa del lenguaje. Frases tales como "nadie te amará tanto como yo", "nadie te comprende de esta manera", "somos almas gemelas" o 
expresiones similares que encontramos a menudo en la literatura, ejercen un impacto en el interlocutor de la carta real.

Sin embargo, para que emisor e interlocutor intercambien frases semejantes es necesario que hayan entrado previamente en un arreglo tácito de comunicación, en donde se establecen jerarquías, formas discursivas, códigos interpretativos, representaciones y manipulaciones del lenguaje. En el epistolario de Borrero, por ejemplo, el tono íntimo de las cartas se profundiza gradualmente. En el de Avellaneda, sin embargo, fluctúa entre el acercamiento o distanciamiento que dictara aquella tempestuosa relación sentimental. Al acuerdo que determina el modo de comunicación entre las entidades epistolares es lo que conocemos como el pacto epistolar.

Al igual que en el pacto lúdico entre el lector y el escritor, el emisor y el receptor de una carta concuerdan en una serie de representaciones que sólo son válidas dentro del limitado círculo de su relación escrita. Aunque para un tercer lector las representaciones del emisor parezcan alejadas de la realidad, éstas deben resultar siempre genuinas al interlocutor. Cada relación epistolar establece sus propias leyes de intercambio, y éstas funcionan para salvaguardar y preservar el acuerdo. Avellaneda, por ejemplo, entra en un acuerdo epistolar haciendo esta salvedad: "no fue nunca más sincera, más franca, que la que yo estoy dispuesta a hacer a usted". A esa salvedad añade un tono solemne, "Pero exijo dos cosas" (Avellaneda 49). Una vez que se establece el acuerdo epistolar, se cierra un cerco alrededor de un espacio expresivo de comunicación íntima: un mundo epistolar.

Dentro de un pacto epistolar intervienen más de dos entidades: el escritor o autor y el "yo" textual, entidad que utiliza la primera persona y evoluciona a través del texto; luego está el "tú" textual, en desarrollo y en total dependencia del emisor; y por último el 
receptor o lector. Cuatro entidades participan en un mismo acto de comunicación, cuando el autor se desdobla en una de sus muchas entidades epistolares, y habla a una entidad textual que también se formula a través del texto. Se convierte en un "doble proceso persuasivo" cuando el lector acepta ambas representaciones, la del escritor y la de sí mismo (Guillén, "El pacto” 88). Es así que el escritor se vale de entidades textuales para garantizar la mejor recepción de su mensaje.

Alejada de los estamentos de poder, la carta jugó un papel importante para que la mujer obtuviera cierto grado de protagonismo. En ese sentido, el pacto epistolar guarda una semejanza con el acuerdo que existe entre individuos bajo un sistema de poder: "las relaciones de poder pueden ser el resultado de un previo o permanente consentimiento..." (Foucault, "El sujeto" 252). El poder no es un arte que se improvisa, requiere de grados de racionalización, y de la presencia de un individuo que, de acuerdo a los "efectos de la palabra", se someta a un agente capaz de "guiar las posibilidades de conducta y disponerlas con el propósito de obtener posibles resultados" (Foucault, "El sujeto" 253, 256-257). Aunque el pacto epistolar establece relaciones de jerarquía generalmente permanentes, el escritor de turno acierta a tener cierta medida de autoridad, en virtud de ejercer el poder de la palabra.

Escribiendo cartas la mujer encontraba la posibilidad de reajustar su imagen y de influir en otros, pero para dedicarse a la escritura necesitaba proveerse de ciertos recursos: "women must have money and privacy in order to write - is inevitable connected to questions of class... Genius needs freedom" (Gordon viii). Virginia Woolf explica los obstáculos que encontraba la mujer para llegar a ser un profesional de las letras en su ensayo A Room of One's Own, de 1929. Simone De Beauvoir habla además 
de las limitadas actividades que eran permitidas a la mujer, lo que con frecuencia la inclinaban a abrazar causas que correspondían a su reducido campo de acción: "she is not permitted to do anything; so she persists in the vain pursuit of her true being thorough narcissism, love, or religion" (679). Así, tanto en principio como en recursos, algunas mujeres vieron en la vida de convento la oportunidad de dedicarse a tareas intelectuales, alejadas de las tareas del hogar y los problemas económicos. ${ }^{17}$ Aunque la mayoría de las mujeres no lograron destacarse en la literatura, es "abundante y variada la escritura conventual española... es un hecho incuestionable que la religiosa española del Siglo de Oro escribe,...” (Herpoel 210,213). Retomemos este tema para ilustrar la función de la escritura hacia un mayor protagonismo de la mujer.

Saber leer y escribir era crucial para que la mujer dejara oír su voz durante la temprana Edad Media, aunque la religiosa iletrada se valió de la práctica generalizada de dictar cartas. Escribiendo o dictando cartas, la religiosa evadía la rigidez de la retórica medieval, improvisaba estructuras y hacía uso de las lenguas vernáculas en lugar del latín. Muchas de estas cartas trascendieron el confinamiento del convento, al ser leídas a una comunidad particular (Cherewatuk and Wiethaus 15). Cuando una religiosa alegaba haber tenido una experiencia mística, a veces su confesor le aconsejaba ponerla por escrito, y él u otro lector evaluaban su experiencia. Estos relatos guardaban cierto paralelo con la escritura epistolar: ambos proyectos contaban con un emisor, un pretexto de escritura y un lector, en diferentes grados y funciones de censor.

\footnotetext{
${ }^{17}$ Tal fue el caso de Santa Rosa de Lima (1586-1617) quien, por huir de un matrimonio arreglado por su familia, hizo voto de virginidad y luego ingresó en la orden de santo Domingo de Guzmán.
} 
La función del lector o censor de la escritura conventual resultaba ser una suerte de destinatario. Su presencia silente controlaba el texto a medida que se desarrollaba, así como también a veces propiciaba e inspiraba la escritura misma: "La presencia de un interlocutor mudo determina en gran medida la selección y presentación de lo narrado. Sus consejos y precisiones actúan como una forma de control ideológico, aunque cabe añadir que el dominio masculino sobre el discurso de la mujer no es todo lo absoluto..." (Herpoel 217). La relación que se desarrollaba entre religiosa y censor podía durar años, y funcionaba también a través de un convenio tácito. La autobiografía epistolar de Avellaneda, por ejemplo, parte de un pretexto de confesión semejante al que inspiraba la escritura conventual.

Relatar experiencias místicas, amparadas por la autoridad del confesor dio a algunas religiosas un medio por el cual expresarse. Sus relatos y sus cartas no sólo despertaban la curiosidad, sino también el respeto de las autoridades eclesiásticas. Este fue el caso de las cartas de Hildegarda de Bingen, la abadesa alemana, quien somete sus experiencias místicas a su confesor. Por el protagonismo que adquiría con estos relatos, la religiosa a veces obtenía aquello que se proponían, por ejemplo, la formación de una orden, la fundación de un monasterio, y hasta la reforma de la Iglesia. Esta manera de alterar el orden jerárquico no tenía menos que provocar una reevaluación o reinterpretación de su propia imagen. Acerca de la relación entre la formación del sujeto y su enfrentamiento al poder, Foucault explica: "Finalmente todas estas luchas giran en torno a la pregunta “¿Quiénes somos?” (“El sujeto”, 245). Así, la escritura de la religiosa le procuraba una forma de protagonismo, en un tiempo en el que se esperaba de ella la sumisión y el silencio. 
Además de escribir sobre temas de naturaleza espiritual, la mujer se acogía al tema del amor, con lo que también lograba cierta forma de influencia. Escribiendo cartas de amor establecía un diálogo en el que dejaba de ser el objeto de la interpretación ajena, para convertirse en un sujeto pensante. Usó además esa oportunidad para seducir por el efecto de la palabra, con lo que la carta se convertía en un instrumento de poder. Las relaciones de poder funcionan como acuerdos entre individuos que persuaden o se dejan persuadir: "[el ejercicio del poder] es una estructura total de acciones dispuestas para producir posibles acciones: incita, induce, seduce, facilita o dificulta: en un extremo, constriñe o inhibe absolutamente; sin embargo, es siempre una forma de actuar sobre la acción del sujeto... un conjunto de acciones sobre otras acciones (Foucault, "El sujeto" 253). Nótese que el ejercicio del poder se define como un conjunto de acciones que "incita, induce, seduce", funciones que caracterizan a la misiva amorosa. La carta era la oportunidad que tenía la mujer de llamar la atención sobre sí, sobre sus necesidades e inquietudes como individuo.

Algunas autobiografías y cartas han llamado la atención de la crítica contemporánea por su valor testimonial. El testimonio se caracteriza por su inmediatez, es decir, por su poder de acercar al lector a un acontecer en el tiempo: el "testimonio" es el "conjunto de modalidades discursivas que tienen en común dar voz a los silenciados, desterrar las historias reprimidas por la historia y el discurso dominante..." (Zavala, Breve historia I 73). Pero además de informar, algunos de esos testimonios revelan la tarea del comunicador, es decir, del escritor capaz de establecer conexiones memorables con el lector. Ciertas cartas han creado vínculos permanentes con el lector en diferentes épocas, y han despertado el interés no sólo por su valor informativo sino también por el 
estético. Así, a través del tiempo, algunos de estos documentos se han colocado a medio camino entre la escritura testimonial y la creación literaria.

\section{Los epistolarios de amor de Avellaneda y Borrero: la persuasión como arte.}

A los epistolarios de Avellaneda y Borrero los caracterizan la intención de persuadir y el afán de auto-definición, y fueron escritos con una marcada preocupación estética. Esta escritura buscaba impactar al lector y persuadir por el poder del lenguaje. El tema del amor además les abría espacios para las manifestaciones del ser, lo que contribuía a la mirada introspectiva y a la consolidación de la identidad. Con tal marco de composición, la escritura de estas mujeres se "literaturiza", por lo que muchas de sus cartas adquieren las dimensiones de los textos que Guillén coloca "al borde de las instituciones literarias" ("El pacto" 78).

Desde las Heroidas hasta hoy, el tema de la ausencia aparece con frecuencia en la escritura de mujer, es el tema por excelencia de la carta de amor. Salinas explica que la circunstancia de la ausencia es la misma esencia de la carta de amor, "una situación psicológica nueva entre ellas dos y que demanda nuevo tratamiento. Este trato, en la lejanía es la correspondencia" (49). La ausencia y la queja romántica era uno de los mejores pretextos de escritura, de explorar con la imaginación temas no anticipados. Para Avellaneda, la queja de amor a veces se convierte en una manifestación poderosa del ser, que dejaba una marca profunda en la escritura: “¿Es amor esto? No, hay algo de más, no es amor solamente. Es el infierno, que se ha venido a mi corazón" (Avellaneda 104). La queja romántica en Borrero también se manifiesta de manera parecida: "Tus conjuros me intimidan, tus frases que envuelven indudablemente amenazas, me causan una angustia inexplicable..." (EI 112). La mujer, sobre quien pesaban las convenciones 
patriarcales, encontraba que el tema del amor era una puerta hacia múltiples posibilidades: "la carta es a muchos niveles una liberación...pura escritura liberadora, susceptible de superar el efímero presente” (Guillén, “El pacto 83, 90). Así el pretexto epistolar era una ocasión de pronunciarse desde la intimidad, de dejar oír los desgarramientos del ser y activar la imaginación.

Jacques Lacan y Julia Kristeva coinciden en que la escritura femenina se asocia con lo imaginario, es decir, con una etapa del desarrollo humano que precede a la adquisición del lenguaje (en Díaz-Diocaretz 42). El discurso masculino, por otra parte, se caracteriza por lo fijo y lo estable, lo que conduce hacia lo simbólico, hacia las formas que limitan los significados para permitir que el discurso llegue a ser. Hélène Cixous también asocia la creatividad de la mujer con lo imaginario. El discurso femenino (parler femme y ècriture féminine) tiende a la sensación de lo inefable o lo indefinido, "lo abierto, lo inestable y el juego verbal” (Díaz-Diocaretz 42, 43). La inclinación hacia lo imaginario suplía la incapacidad del lenguaje patriarcal de reproducir con fidelidad las experiencias de la mujer: "Jamás el lenguaje ha sido más indócil ni más insuficiente tampoco" (Borrero EI 256). Aunque Salinas opina que la inclinación de la mujer a la escritura epistolar se debe a "algún rasgo psicológico particularmente femenino" (70), parece ser más bien que ésta escribía cartas porque por mucho tiempo se vio limitada a ese género de escritura.

La mujer acertaba además en hacer del tema del amor uno de sus mejores pretextos de escritura. Es en el tema del amor, según Julia Kristeva, en donde se “conjuga inextricablemente lo simbólico, lo imaginario y lo real” (en Guillén "El pacto 95, 96). Borrero, por ejemplo, encontraba que el poder de la imaginación era un sino 
ineludible que gobernaba la redacción de sus cartas de amor (EI 277). El tema del amor y la inclinación a lo imaginario eran atajos con los que la carta llegaba a convertirse en una expresión artística. Muchas de las mejores manifestaciones de la imaginación en Borrero y Avellaneda se encuentran en forma de cartas.

Aunque en apariencia escribir una carta es una actividad espontánea, su diálogo diferido depende de la habilidad del escritor de recrear la presencia del interlocutor, una invitación a la creación artística: "me resisto a ese concepto de carta que la tiene como una conversación a distancia como... diálogo imposible" (Salinas 29). Esa recreación de la presencia del interlocutor es una de las muchas y variadas situaciones del uso de la imaginación en la escritura epistolar. En ello intervienen los enunciados metacomunicativos, o las indicaciones contextualizadoras, como "En mi habitación. Misiva nocturnal" (Borrero, EI 185), los cuales terminan por darle un sesgo estético a lo que de otro modo sería sólo un mero instrumento de comunicación. Ese marco interpretativo que propone el escritor para su mensaje se denomina diseño interno del evento comunicativo (Soto Vergara 156, 160).

La carta es además una herramienta de realización personal, una oportunidad de auto-remitirse al estado físico, sentimental y emocional del escritor (Tin 10). Aunque esperamos que la auto-representación del que escribe una carta sea genuina, la escritura le ofrece múltiples recursos de representación. Borrero, por ejemplo, a veces habla desde la entidad que anhela "poseerte y de ser tuya", mientras que en otras quien habla es "tu virgen", "tu dulce novia" ( $E I$ 39, 51). Tales representaciones van dándole forma a una imagen textual que varía de acuerdo al propósito de la escritura: "Sólo a través del simulacro de la escritura se constituye al sujeto ficticio, dejando al sujeto real como un 
ente inasible, colocándose continuamente en otro lugar" (Castillo 11). A las diferentes entidades o representaciones que el emisor hace de sí mismo reconocemos como el autor implícito.

El autor implícito se manifiesta en función del propósito de su carta, al igual que el artista se caracteriza al representar diferentes personajes, el artista es una especie de impostor (Peyre 326). Esta relación del autor con su imagen textual lo coloca entre la realidad y la pretensión. Dentro del contexto literario, Wayne C. Booth reconoce en el autor implícito la capacidad de mostrarse bajo diferentes luces, dentro de diferentes textos: "Just as one's personal letters imply different versions of oneself, depending on the different relationships with each correspondent and the purpose of each letter, so the writer sets himself out with a different air depending on the needs of particular works" (71). Al igual que un actor seduce al espectador con la interpretación de su personaje, el emisor se transforma en diferentes entidades como parte de un proceso persuasivo. De ahí, lo que Guillén llama "la ambigüedad del producto", es decir, al resultado final de una carta en la que el emisor crea o modifica la imagen textual que lo representa (Guillén, "El pacto" 82,83$)$.

No sólo el emisor adopta diferentes entidades textuales, sino que también elabora una imagen textual del destinatario, lo idealiza. La entidad del interlocutor evoluciona y se actualiza a través del texto. Siendo que por tanto tiempo a la mujer se le había limitado el derecho a expresarse, ella necesitaba de una presencia textual para dialogar o ante quien confesarse. De esa manera podía comunicarse desde una posición menos pretenciosa (Prado 19). Avellaneda, por ejemplo, eleva la entidad de Cepeda como "ministro del cielo", ante quien se dispone a la confesión (49), mientras que Borrero se 
dirige a Carlos Pío con semejante tono confesional: "con usted no quiero ni puedo mentir" (EI 53).

La carta de amor adquirió su fluidez expresiva gracias a la influencia del billete amoroso. El billete era un brevísimo mensaje escrito que tuvo gran circulación en las sociedades europeas, del que la carta familiar heredó el uso de la imaginación, la libertad expresiva, el malabarismo intelectual y el juego estilístico, una invitación para escribir arte (Bernardo 57, 173). ${ }^{18}$ Sus elementos de seducción facilitaron la función doble que adquirió la carta: como vehículo comunicativo y también literario. Así, el billete se coloca entre las convenciones sociales y la expresión individual. Sus elementos (declaración, petición desesperada, negativa de la dama, insistencia del reclamante y rendimiento de la dama) se valían de fórmulas que combinaban el lenguaje poético con el lenguaje popular. ${ }^{19}$ El billete o brevitas, dio paso al amplificatio o carta, y su ornamento y técnicas de seducción encuentran una misma fuente en la historia literaria. Sirvió además, desde el punto de vista sincrónico, para observar el impacto en la literatura, así como para la valoración posterior de la carta de amor como género literario menor.

Aunque la calidad estética de los epistolarios de Avellaneda y de Borrero es bien reconocida, no existe un consenso en cuanto a cómo determinar la especifidad literaria de la carta en general. En torno a este tema, Marie-Claire Grassi opina que una carta "literaria" se distingue no por su naturaleza, sino por los grados de literariedad que contiene de acuerdo a la estética universal (5). De acuerdo a lo anterior, el tema de la

\footnotetext{
${ }^{18}$ El billete había circulado en la sociedad europea durante los siglos XVI y XVII.

${ }^{19}$ Remedando el estilo del billete amoroso, Cervantes inmortaliza uno en su novela, Don Quijote: "Soberana y alta señora: El ferido de punta de ausencia y el llagado de las telas del corazón, dulcísima Dulcinea del Toboso, te envía la salud que él no tiene" (157).
} 
literariedad no es un asunto de clasificación, sino de grados o incidencias en los que características propias de la literatura intervienen en la escritura de una carta. Estas características deben coincidir con los modelos de estética universales, lo que explica en parte por qué algunas cartas apelan al lector de diferentes épocas y otras no. De acuerdo a Guillén, ciertas cartas superan "la severa dicotomía que divide las cartas en dos áreas o campos absolutamente heterogéneos", la real o pragmática y la literaria (Guillén, "El pacto" 78).

Pedro Salinas describe la carta de amor como "un entenderse sin oírse" (29), lo que implica una tarea mucho más compleja que un simple acto de comunicación. Aunque Avellaneda, por ejemplo, ordenara a Cepeda que el fuego devorase "este papel inmediatamente que sea leído", el carácter privado no alteró el carácter estético de sus cartas:

El sentido de una obra de arte no se agota en su intención, ni siquiera es equivalente a ésta. Como sistema de valores, lleva vida independiente. El sentido total de una obra de arte no puede definirse simplemente en función del sentido que tenía para su autor y sus contemporáneos. Es más bien el resultado de un proceso de acumulación, es decir, la historia de su crítica por parte de sus muchos lectores en muchas épocas (Wellek $52)$.

No limitada por su intención original, Selimov advierte que Avellaneda "adapta un lenguaje literario a su situación personal, es decir, literaturiza su reacción individual ante una problemática existencial...” (26). Vitier encuentra además en las misivas de Juana 
"una especie de grandeza shakesperiana", aún cuando el delirio de la enfermedad le nublaban la razón ("Prólogo" 22). Así algunas de estas cartas añadieron a su función original una cualidad estética que alteraba su naturaleza enteramente pragmática.

En el pasado ciertas cartas se identificaban con el arte tanto como las ficticias, por lo que la labor de su deslinde llegó a ser una tarea complicada. Ese equívoco fue dramatizado cuando la publicación de Las cartas de una monja portuguesa burló por muchos años la credulidad de los incautos. ${ }^{20}$ Para ilustrar la ambigüedad en la clasificación de algunos textos, Guillén utiliza el caso de la comercialización de los tratados y modelos de escritura epistolar que circularon a raíz del renacer y del auge de este género en las sociedades europeas. ${ }^{21}$

La función de los modelos epistolares era enseñar a escribir cartas, tarea que en gran parte pertenecía a la retórica. Surgía además la tarea que tenía que ver con el marco circunstancial que contextualizaba la producción de aquel modelo. Ese proceso contextualizador del mensaje fácilmente implicaba adentrarse en una dimensión ficcional. Era una atracción irresistible hacia la creación artística, en la que el escritor cruzaba, sin proponérselo, la frontera de lo imaginario, una "tentación" en la escritura (Guillén, "El pacto" 81). En relación al epistolario de Avellaneda, Selimov define la ficcionalidad como una característica en función y condicionada por la imaginación del remitente, lo que convierte las cartas en un "manifiesto espiritual" (24). En cuanto a la ficcionalidad, Guillén explica: "el reconocimiento de la ficcionalidad nos conduce a dar cabida a cartas

\footnotetext{
${ }^{20}$ En las Cartas de amor de la monja portuguesa (1668), de Mariana Alcoforado, las notas autorreferenciales aportan verosimilitud a las cartas mismas: "Cuando os devuelva vuestras Cartas me quedaré con las dos últimas que me escribisteis y las releeré mucho más a menudo de lo que leí las primeras ... (57).

${ }^{21}$ Guillén apunta a los manuales de Gaspar de Texeda, de 1549 y de Francesco Sansovino, de 1568.
} 
que no son literatura, o que lo son ambiguamente, o que se encuentran al borde de las instituciones literarias; y por lo tanto superan, gracias a la vasta dimensión de lo ficcional, la severa dicotomía que divide las cartas en dos áreas o campos absolutamente heterogéneos ("El pacto" 78). Pero además de la ficcionalidad, la inclinación inherente del lenguaje a la expansión convierte a algunas cartas en invitaciones en la creación artística. Para Avellaneda, esta propensión del lenguaje a amplificarse era un impulso que no era capaz de resistir: "mi pluma corre a pesar mío, y dice más de lo que quiero decir" (94). Pedro Salinas ha llamado a esa característica del lenguaje, "misteriosas leyes de hermosura" (43). Pero además de la ficcionalidad y de la expansión del lenguaje, otros documentos encontraron su camino a la literatura por medio de diferentes modalidades discursivas, como es el caso de las crónicas.

Para muchos el debate epistolar no es un asunto epistemológico y literario, sino ontológico, la labor de reconocer en el texto la expresión íntima del ser, la "presencia y función del sujeto" (Pulido Tirado 5). La pregunta de Foucault "What Is an Author?", nos lleva a reflexionar en el momento de la historia literaria en la que la mujer se da cuenta de que posee esa posición privilegiada, por ser capaz de manifestarse como sujeto. Antes de ese despertar de auto valoración, la mujer ocultó su talento literario al dedicarse a la escritura secreta, como diarios y cartas. Otras mujeres que se dedicaron a la literatura descubrieron que su condición femenina determinaba el poco o ningún grado de circulación que tenían sus textos.

Para ilustrar cómo afecta a la valoración de un texto su capacidad de circulación, Foucault explica que una carta privada contiene un signatario, pero no un autor. La función de un autor se caracteriza por el modo de existencia y la circulación del texto que 
firma, lo que hace que una carta privada no tenga un autor ("What Is an Author?", 982). Por siglos la mujer se dedicó a escribir documentos íntimos, por lo que el reconocimiento de esa tarea privada se vio afectado por carecer de una evaluación crítica. No obstante, los epistolarios que se han hecho públicos, como los que aquí nos ocupan, se han integrado a un medio de circulación, situación no anticipada que invita a una relectura.

Carta, poder $\mathrm{y}$ arte se vinculan en una concatenación de mecanismos $\mathrm{y}$ circunstancias, hacia una mayor participación de la mujer en el ámbito social y literario. La carta desempeñó un importante papel en su realización como sujeto, ya que favoreció el proceso gradual de auto reconocimiento. Pero además, escribiendo cartas la mujer se ejercitaba en un arte que contaba con una larga tradición literaria. Algunos de los críticos que revisitan hoy el tema epistolar coinciden en que "una carta es una pequeña pieza literaria", así como también lo han reconocido en la obra epistolar de Avellaneda y Borrero (Carles Bastons i Vivanco 236).

Resta, sin embargo, mediante un proceso revisionista, precisar qué rasgo de ruptura y continuidad aportan las cartas en cuestión a la tradición epistolar femenina; cómo trastornan el paradigma de la conquista amorosa; de qué manera contribuyen a la toma de consciencia hacia la formación del sujeto femenino; cuál es su legado en la marcha hacia un mayor protagonismo social y literario. Por último, por qué medios de escritura la comunicación íntima de estas mujeres se transforma en un acto de creación estética, asuntos que precisan dirimirse desde una valoración práctica. 


\section{Capítulo II.}

\section{El epistolario de Avellaneda: el poder de la persuasión.}

\section{Avellaneda a la vanguardia de una época.}

Los epistolarios amorosos de Gertrudis Gómez de Avellaneda componen un proyecto de introspección, en donde bosqueja una propuesta inédita de identidad femenina. A la vanguardia de tal postura, la escritora cubano-española abogaba desde la intimidad por un mayor protagonismo femenino en la vida social y literaria. Partía además con un modelo original de persuasión y de conquista amorosa, que le permitía cuestionar constructos sociales ante individuos que formaban parte de la consciencia hegemónica. Su estrategia consistía en proyectar su drama sentimental sobre nuevos contextos, para con ello reflexionar sobre el destino de la mujer. Con todo ese quehacer de renovación ideológica, la escritora cubana rompía con los esquemas paradigmáticos de escritura epistolar. Eran los comienzos de revisar y reescribir la cultura de la escritura íntima de mujer.

Gertrudis Gómez de Avellaneda ("Tula") había nacido en Camagüey en 1814. Su padre era un oficial de la Marina española y su madre una joven cubana rica. Recibe una esmerada educación que complementa con su voluntad autodidacta. A los 18 años publica su primer soneto en el Diario de La Habana. En 1836 llega a Galicia con su familia, para luego viajar a Sevilla en 1838, en donde publica en periódicos y revistas. Estrena su primer drama Leoncia en 1840 y al año siguiente publica en Madrid la primera edición de sus poesías. De regreso a Cuba, bajo su dirección se publica el Album Cubano de lo Bueno y lo Bello, con el que se coloca a la vanguardia de la única revista de la Cuba colonial para mujeres. Escribió más de 20 obras para escena, 6 novelas, 9 relatos o 
leyendas, además de artículos literarios y ensayos. Avellaneda muere en 1873 en Madrid, a la edad de 59 años, y fue enterrada en Sevilla, como estipula en su Testamento. ${ }^{22}$

Avellaneda escribió también dos significativos epistolarios. El primero lo comienza en julio de 1839, a la edad de 25 años, cuando el romanticismo español era un asunto "exclusivamente masculino" (Kirkpatrick 259). Lo dirige a Ignacio Cepeda, con un total de 53 cartas precedido por 7 relatos autobiográficos. ${ }^{23}$ Lo concluye en Madrid, el 26 de marzo de 1854: "Adiós, otra vez, querido; cree que es tu mejor amiga, Tula" (I, 53). El segundo epistolario está dirigido a Antonio Romero Ortiz, y pertenece a la primavera de 1853. Con un total de 50, estas misivas concluyen el 17 de marzo de 1871: "A Dios, mi estimado amigo, no se dedique V. exclusivamente a la ingrata política, que como el viejo Saturno se alimenta devorando a sus propios hijos, [...]" (II, 50).

El presente estudio intenta demostrar que los epistolarios amorosos de Gertrudis Gómez de Avellaneda documentan el impacto del movimiento cultural del romanticismo en la renovación del sujeto femenino. Escritoras a la cabeza de ese reajuste de identidad, terminaron enfrentándose, como Avellaneda, ante la sociedad y ante sí mismas. Con este propósito, me enfoco en tres períodos o momentos de su escritura epistolar. El primero comienza con la "Autobiografía" de 1839 y el grupo de cartas que termina en abril de 1840. Este es un período de auto-reconocimiento y fijación de imagen, el tiempo para crear el mito de identidad que ha prevalecido hasta este día. El segundo ocurre entre febrero y noviembre de 1847 , período de su primera viudez y de su reencuentro con

\footnotetext{
${ }^{22}$ Se ha fundado La Asociación Cultural y Literaria La Avellaneda (ACLA), con el propósito de impedir que los restos de la poetisa sean trasladados a Cuba. Ver entrevista de la escritora Edith Checa, en http://gertrudisgdeavellaneda.blogspot.com.

${ }^{23}$ En la edición de Selimov que usamos como base de este trabajo, existen dos relatos marcados como "IV", lo que convertiría en un total de 8 relatos autobriográficos.
} 
Cepeda. Es entonces cuando, con perspectiva crítica, Avellaneda se ocupa del amor como el gran sentimiento del ser. Finalmente, la tercera etapa transcurre durante la primavera de 1853, mientras escribe un segundo epistolario que dirige a Antonio Romero Ortiz. Tras haber enfrentado numerosas batallas profesionales y reveses sentimentales, la poetisa realiza una deconstrucción de la pasión amorosa y un atrevido reconocimiento del deseo, desmontando así el discurso patriarcal sobre la sensualidad femenina.

La doble agenda del epistolario de Avellaneda, la de conquista amorosa y la de conquista de espacios expresivos para la voz de la mujer nueva, se realizan a través de estrategias de escrituras con las que controla el texto e intenta influir en su lector. Su tras-discurso, el del propósito inmediato, es el de la persuasión tras el discurso del romanticismo. Pero su trans-discurso, es decir, el del enfrentamiento ideológico, es el que se preocupa por el destino social de la mujer. Con esta visión doble, me aproximo a sus cartas desde los siguientes temas generales: Avellaneda ante sí misma, ante la sociedad, ante el amor y ante la pasión.

\section{Avellaneda frente a sí misma: un mito lírico de identidad. \\ “Autobiografía," III.}

Entre la confesión sentimental y la creación artística, Avellaneda comenzaba a escribir una autobiografía para un único lector, Ignacio Cepeda. Éste era un joven estudiante de 23 años, a quien conoce en Sevilla en 1839. Escribía a sólo tres años de haber salido de Cuba, en donde había transformado la sociedad cerrada sin acceso al mar en la que vivía, "rebelándose contra sus principios rígidos, en el espacio de la escritura literaria" (Arrufat, "Páginas" 8). Esa actitud rebelde tenía la influencia del neoclasicismo y del romanticismo francés, por lo que un romanticismo "ecléctico" marcaba el tono 
lírico de sus cartas. ${ }^{24}$ Seguía además el concepto romántico que proclamaba que el arte podía equivaler a la experiencia humana. Por ser ésta una autobiografía epistolar, su estructura dependía de acuerdos implícitos con el lector que emulaban entre sí: el pacto autobiográfico y el epistolar. Una variedad de voces yuxtapuestas convergían en esos textos, con las que intentaba "manipular las formas codificadas del lenguaje y trascender la imagen atrapada en el espejo de los otros" (Pagés-Rangel 131).

Avellaneda escribe su autobiografía en la España de Isabel II enfrentada a la Primera Guerra Carlista (1833-1840). Compartía el impulso intelectual con el que la Península intentaba modernizarse, en donde una variedad de periódicos y revistas presentaban al romanticismo como un fenómeno cultural. En la literatura de la época se destacaban el Duque de Rivas, Fernán Caballero, Mesonero Romanos, Larra, Varela, Bécquer, Rosalía de Castro, Galdós, Pardo Bazán y Clarín, y en el teatro triunfaban $L a$ conjuración de Venecia (1834), Don Álvaro o la fuerza del sino (1835), El trovador (1836) y Los amantes de Teruel (1837). La pluma de escritora cubana se alentaba con el espíritu de independencia que cuestionaba el papel subalterno de la mujer, por lo que era inevitable que Avellaneda se enfrentara ante sí misma.

La carta que nos ocupa, A la una de la noche, es parte del tercer relato de un "cuadernillo" autobiográfico. El texto interrumpe la narración lineal que comenzara el 25 de julio de 1839 para tratar un asunto que le preocupaba: la conducta evasiva de su interlocutor. El distanciamiento de Cepeda era reflejo del "susto" con que el hombre acogía la imagen de la mujer en transformación (Prado 36). La importancia de la misma

\footnotetext{
${ }^{24}$ Literatura hispanoamericana. Anderson Imbert/Florit. Tomo I, pág. 313.
} 
reside en que Avellaneda se ampara tras su imagen autobiográfica para apropiarse de la autoridad con la que ahora se dirige a su interlocutor:

¿Pero habrá de continuar usted un género de vida semejante?

No es cierto que el solo disgusto de la sociedad le inspire a usted esa especie de misantropía; no, no es posible. Se necesita

haber padecido mucho, haber sido la víctima de la sociedad para aborrecerla en ese grado. [...] Yo, que he padecido sin duda penas más reales que las que usted pueda tener, yo que conozco tanto como usted, por los menos, el mundo y la sociedad, no siento esa misantropía; y aunque no vea ni a la sociedad ni al mundo al través del encantado prisma de las ilusiones, aún conozco que necesito del uno y de la otra [...].

Este paréntesis autorreferencial interrumpía en la narración lineal autobiográfica, pero retenía la imagen protagónica de aquellas vivencias. Esa entidad en proceso de formación, ahora resultaba serle útil a corto y a largo plazo. Como género, la autobiografía se define como la creación "de la autoconciencia de un sujeto ficcional, textualización que se prefigura como sujeto heroico en una construcción enunciativa" (Rodríguez 22). El autógrafo, como aquí lo era Avellaneda, asume una entidad ficticia semejante a la de un actor que representa un libreto (Peyre 325). Tal entidad épica, producto de las experiencias de su vida, le suministraba ahora la autoridad para confrontar el comportamiento de su interlocutor.

El sentimiento de atracción/rechazo que Cepeda sentía por la escritora explica el distanciamiento que era ahora el objeto de la carta. Por un lado le atraía la personalidad 
de aquella extranjera indómita, pero por otro le consternaba su actitud independiente. No era de extrañar que Avellaneda quisiera justificar su conducta desde el principio de su relación, aunque para ese tiempo la autobiografía era un género eminentemente masculino. Sin embargo, al adoptar el género, demostraba así la influencia literaria de sus lecturas y de los paradigmas románticos (Kirkpatrick 135). ${ }^{25} \mathrm{Al}$ justificar su modelo de vida, la autobiografía se convertía además en una tarea de introspección. Éste era un ejercicio vital para el sujeto romántico, dada la autenticidad con la que pretendía enfrentar sus contradicciones. Avellaneda se enfrentaba a múltiples contradicciones, una de las cuales era por estar inmersa en un proceso de aculturación. La cultura es, según Foucault, "el campo de batalla en que la verdad es una función del poder" (en Picon Garfield 10).

Cepeda encontraba que la conducta de Avellaneda no era compatible ni con el modelo cultural de la mujer peninsular, ni tampoco con el modelo de comportamiento de la sociedad decimonónica. Eso podía explicarse en base a su condición de mujer criolla y a su identificación con el fenómeno cultural del romanticismo. Una mujer española de su clase se habría dedicado a las tareas domésticas y religiosas, y jamás habría estado expuesta a los libros que Avellaneda había leído (Kirkpatrick 132). De manera que la escritora sentía la urgencia del autógrafo de explicar una conducta ambigua, por medio de organizar e interpretar los hechos de la vida. Tal proceso se convertía en una tarea de introspección y autodefinición (Pastor 49).

\footnotetext{
${ }^{25}$ Las producciones autobiográficas durante el siglo XIX se inspiraron en Las Confesiones (1782) de JeanJacques Rousseau.
} 
La autoridad con la que Avellaneda se dirige a su interlocutor en el pasaje anterior ("no es cierto que el solo disgusto [...]") dista mucho de la actitud inicial de su autobiografía. Al principio del relato dos cartas atrás, la había comenzado adoptando una actitud confesional de tono lírico. Cepeda, como interlocutor autobiográfico, era parte de "lo no-verbal" y de la estructura del enunciado (Zavala, Breve historia III 49). Tal actitud inicial se aseguraba de retener la atención y la empatía de su lector: "La confesión, (el motivo lírico o tema) que la supersticiosa y tímida conciencia arranca a un alma arrepentida (hablante lírico) a los pies de un ministro del cielo (objeto o ente que inspira), no fue nunca más sincera, más franca" (actitud lírica). ${ }^{26}$ La lírica es el "centro del discurso psicológico, introspectivo, rememorativo, evocativo o fantástico con que se determina la experiencia del yo" (Marchese y Forradillas 244). Por el carácter rememorativo y evocativo de aquellos relatos, la lírica era el discurso que optaba Gómez de Avellaneda para transcribir su experiencia humana. Tal actitud lírica era consistente además con su obra poética. ${ }^{27}$

La autobiografía se distingue por su carácter de "otredad", es decir, de la autoidentificación del sujeto a través de la mirada del otro. A Avellaneda, como a las escritoras decimonónicas, le preocupaba obtener la aprobación del hombre culto como Cepeda. Es por eso que decide comenzar su relación sentimental con él, sobre la base de sus propios méritos. Doris Sommers establece un paralelo entre la autobiografía de Avellaneda y su novela $S a b$, novela fundacional de reconciliación nacional desde el

\footnotetext{
${ }^{26}$ Hay una conexión directa entre la autobiografía y la confesión en la novela: "La carta se ha prestado siempre a la confidencia y la confesión; a la altura de 1554, estaba, además, bien curtida en la autobiografía" (Rico, 19).

${ }^{27}$ El estilo poético de Avellaneda se define como "una fuerza natural en libertad". Ver Literatura Hispanoamericana. Anderson Imbert/Florit. Tomo I, pág. 313.
} 
punto de vista racial. ${ }^{28}$ En el capítulo "Sab C'est Moi", de su libro Foundational Fictions, Sommers escribe: “And while writing 'Sab's letter,' probably in 1839, Avellaneda is also writing a long autobiographical letter [...]. Gertrudis constructed a new self $[\ldots]$ " $(115,121)$. La lógica de su biografía es similar a las novelas que buscan en el mito literario el fundamento emblemático que agrupa a los individuos bajo un mismo ideal. Aquel "new self” seguía el patrón de las novelas fundacionales más tempranas, en donde "the love affair replaces power with desire" (Sommers 124). Constituyéndose en el objeto de su relato y cronista de su propia historia, Avellaneda se objetiviza para fijar el fundamento de la relación con su interlocutor.

Avellaneda llama la atención hacia el personaje u objeto de sus relatos anteriores: "yo que he padecido". No obstante, en su primer relato escribía, "de usted me ocupo al escribir de mí [...]", como el "Lazarillo" cuyo pretexto narrativo era satisfacer el interés del lector. Aunque Cepeda era el pretexto de escritura, el centro gravitacional era ella y su historia, el yo romántico en detrimento del yo subalterno femenino. Esa entidad ahora generaba la autoridad del autor implícito de su carta. La voz de ese autor implícito se fundía en un solo yo/textual- yo/héroe. Según Bajtín, una autobiografía de carácter literario, como la de Avellaneda, es una manera de objetivar la vida artísticamente (en Rodríguez 20). Todo ese entramado textual formaba parte de un manejo de identidades y representaciones que se desplazaban para validarse mutuamente. En los documentos testimoniales, como lo son las cartas, las autobiografías y los diarios, el autor y el héroe se funden para dar la ilusión de un sujeto centrado. El escritor del testimonio retiene el

\footnotetext{
${ }^{28}$ Se debate la participación de la mujer cubana en la creación del mito fundacional insular, y sólo se acepta su papel como símbolo del paisaje: "Por lo general, la crítica ha omitido e incluso negado el aporte de las escritoras a la invención de un mito fundacional. En el caso de Gertrudis Gómez de Avellaneda (1814-73), excepto en raras ocasiones, se ha dejado pasar desapercibida su versión del mito insular". (Albín 78).
} 
poder de interpretar y de autorizar la propia historia (Zavala, Breve historia I 73). Tal era el propósito de las voces que se entrecruzan en esta carta.

Nótese además que Avellaneda antepone su perfil biográfico como punto de referencia para juzgar la actitud esquiva de Cepeda: "que he padecido sin duda penas más reales que las que usted pueda tener". Esto revocaba su actitud subalterna inicial, y transgredía su posición en la relación social y sentimental entre hombre y mujer. Alteraba además el modelo de escritura epistolar femenina, porque era el papel tradicional de la mujer limitarse a llorar el olvido o el desamor del amante. Pero ahora Gómez de Avellaneda se dirigía a Cepeda como entre iguales. Tanto el sujeto de su enunciado (el yo autobiográfico) como el de la enunciación (el yo epistolar) hablaban con la voz de la mujer emancipada.

Aunque a las cartas de Avellaneda se les haya colocado "debajo de su Obra" (Pagés-Rangel 121), un análisis retórico de esta carta, además del temático, desmiente tal juicio. Su rasgo distintivo son las estructuras paralelas y las contraposiciones entre el "tú" textual ("usted que no tiene motivos"; "usted puede conocer") y el yo autobiográfico ("yo que he padecido"; "yo que conozco"). La emulación y el choque de esas entidades resultaba en una forma de auto definición por contrastes, una construcción de la identidad a través de afirmaciones y negaciones. A continuación, la escritora introduce una pausa reflexiva que rompe con el equilibrio rítmico de los pasajes anteriores: “¿qué secreto es, pues, ese que usted me oculta? ¡Ingrato! Usted se apodera de mi confianza y me rehúsa la suya: justed se llama mi amigo y disimula usted conmigo! Escuche usted".

Avellaneda ahora retoma las construcciones paralelas dentro de un nuevo contexto: "yo seré siempre su amiga de usted, pero conoceré que usted no lo es mío. 
Más; conoceré que es usted capaz de arterías y pequeñas falsedades, conoceré que usted no me ha comprendido, $[\ldots]$ veré en usted un hombre como todos los demás". "Tula" se ocupa del futuro sentimental de ambos, si la actitud esquiva de Cepeda prevalecía. Esto lo hace mediante el uso de verbos en tiempo futuro, ya que éstos tienden a crear un efecto de inestabilidad. Los verbos en futuro y las estructuras condicionales estimulan la imaginación del escritor, porque presentan conjeturas o sucesos no vividos. Con ello Avellaneda dejaba suspendida las ideas en un limbo de significados, y de oráculos sombríos, de acuerdo con el discurso romántico.

Los verbos en futuro del contrapunteo anterior ocurren para la primera persona: “yo seré”, “yo conoceré” (2 veces), “yo perderé” (2 veces), “yo podré”. Tal tono profético indica continuidad de la vida sentimental de la escritora, sobreviviente de un posible desengaño. En contraste, a la segunda persona con frecuencia se le asignan tiempos verbales en presente con connotaciones negativas: "usted no lo es"; "usted es capaz"; "usted no sabe, no puede saber". Avellaneda confina la vida sentimental del interlocutor al presente, negándole el tiempo futuro. Además, el repetido uso del presente tienden a impartir velocidad al texto: futilidad que le asigna a la vida sentimental de su interlocutor. Obsérvese también la reiteración innecesaria del uso del sujeto. El "usted" y el "yo" están siempre presentes en el texto, identificables y materializados. En último caso, ambas presencias textuales expresan el deseo de la escritora de una unión virtual con el interlocutor.

Nuevamente, Avellaneda rompe la pauta rítmica del pasaje, al introducir formas verbales compuestas: "no me ha comprendido", "usted ha decaído". Las formas perfectas de los verbos crean un efecto contrario, es decir, retardan la velocidad del mismo, y crean 
espacios para la reflexión. Pero de inmediato retoma los contrastes en tiempo futuro: "Yo perderé, si así fuere, yo perderé una ilusión, una última ilusión que me ha lisonjeado algunos días; pero usted perderá más: sí. Porque, ¿dónde hallará usted otra amiga como yo?” Esta pregunta retórica lleva implícita la respuesta deseada, es por eso que las preguntas retóricas con frecuencia se usaban en la novela epistolar y en el sermón. ${ }^{29} \mathrm{La}$ escritora la había colocado en la posición estratégica que provocaría un mayor impacto. Es por eso que la pregunta, “dónde hallará usted?”, sigue inmediatamente a la advertencia "usted perderá más".

Otra estrategia lírica de esta carta surge a partir de la personificación de los sentimientos: "Usted no sabe, no puede saber, cuán puro, cuán desinteresado, cuán tierno es el afecto que me inspira". La frase repetitiva o anáfora resalta el valor del sentimiento aludido: "el afecto". "Afecto" ha sido enmarcado con adjetivos calificativos, "cuán puro, cuán desinteresado, cuán tierno". Avellaneda parece apropiarse de las cualidades que atribuye al sentimiento para hablar a través de él. ${ }^{30} \mathrm{Al}$ hablar a través de un sentimiento, la escritora se aproxima textualmente al interlocutor, mientras que el "yo" epistolar se mantiene prudentemente alejado. Aunque el interlocutor tratara de impugnar el poder tras el sentimiento, no podría resistirse al influjo de su afecto. No podría tampoco luchar contra una emoción incorpórea.

\footnotetext{
${ }^{29}$ Compárese, por ejemplo, con la Carta Quinta, de la monja portuguesa (“¿Acaso yo os supliqué que me hicierais conocer la verdad?"), o la Carta 58 en la novela de Laclos.

${ }^{30}$ En otra carta, por ejemplo, atribuye al "sentimiento" las acciones del "yo": "El mismo sentimiento que dictó una carta presidió a la otra" (155).
} 
Una aparente pérdida de control se une ahora al conjunto de estrategias del "yo" lírico: "Pero, ¿a dónde voy a parar?; ¡yo me contradigo!"31 Se explican esas contradicciones en el discurso avelladiano como "el dilema que experimenta en su papel como mujer escritora, y su necesidad de «escribirse» en el discurso" (Pastor 66). Sin embargo, parece además que finge un desconcierto para apelar a la empatía del lector. Su aparente descontrol le sirve para silenciar la voz autoritativa anterior, y moderar el tono con una propuesta más sosegada: "No, caro Cepeda". Nótese que por primera vez en esta carta Gómez de Avellaneda se dirige a su interlocutor por su nombre, agregándole además el adjetivo, "caro". Éste es uno de los pocos adjetivos que la escritora aplica a su interlocutor o a sí misma. La proliferación de adjetivos tiende a derogar la validez de un juicio y a destacar su naturaleza subjetiva. Los adjetivos usados en esta carta rara vez califican al "yo" o al "usted", pero sí avalan a los sentimientos que los representan.

Con un reenfoque del problema tras el cambio hacia un tono sosegado, la poetisa $^{32}$ se acerca a la conclusión de este relato III de la Autobiografia:

si esta amistad perjudica a intereses del corazón más caros, que

si teme usted excite ella celos y origine disgustos a un objeto querido, no se valga usted de pretextos para evitarlos. Oiga usted. Es demasiado noble y pura nuestra amistad para que sufra las sombras del misterio: yo no podré tolerarlo ciertamente; pero si la manifestación de ella puede ofender

\footnotetext{
${ }^{31}$ Compárese con otros pasajes similares: "Esta carta te va a parecer loca, tonta: vas a leer todas las mías que tienes para notar las contradicciones, las inconsecuencias... las hallarás, [...]" (I, 157).

${ }^{32}$ Para esta investigación se usa el término "poetisa" para referirse a la mujer que compone versos. Ver el artículo "Poeta o poetisa", Soledad de Andrés Castellanos de la Unviersidad Complutense de Madrid, del 2 de julio de 2003. http://www.mundopoesia.com/foros/showthread.php?t=419513.
} 
al amor, el amor es primero; la amistad debe ser sacrificada, y lo será: yo lo exijo

Aunque la lucha de las románticas era expresarse por lo que eran y no por lo que la sociedad decía (Prado 38), era imperativo para Avellaneda moderar el tono de su misiva y reconocer que su influencia sobre el interlocutor no podía ser coercitiva. El ejercicio del poder sobre aquellos que se dejan persuadir consiste en "guiar las posibilidades de conducta y disponerlas con el propósito de obtener posibles resultados" (Foucault, "El sujeto" 253). Era preciso entonces que la escritora hiciera un reconocimiento del carácter independiente de Cepeda antes de concluir su carta.

Otra técnica lírica del pasaje anterior consiste en establecer contrastes, ya no entre el "yo"/“usted", sino entre las dos palabras que sintetizan el tema de la carta: el amor y la amistad. La amistad, que es precedida por los adjetivos, "noble y pura", también es "nuestra". Esa relación que los une, no debería sufrir "las sombras del misterio". Nuevamente, aquí se desplaza el significado de una palabra hacia otra. "Misterio" es equivalente a "amor", palabra que ha contrapuesto a "amistad". La amistad que lo une a la escritora debería sacrificarse si ofende al amor, sentimiento que tal vez Cepeda sintiera por otra persona. Es ahora el "yo" el que ahora asume los rigores del sacrificio: "Mi corazón no variará por esto y en él siempre ocupará Cepeda un lugar distinguido". Al dirigirse a Cepeda en tercera persona, nuevamente crea un efecto de distanciamiento, separándolo del "yo" textual quien se dispone a sacrificar la amistad.

Luego de lo anterior, Avellaneda inmediatamente apunta: "Mañana continuaré mi historia". Nótese que la escritora prescinde de la transición al hacer este giro sorpresivo de tema y de tono, para poner fin al asunto que la ocupa. Como la heroína de Las mil y 
una noches, sabe que interrumpir su relato autobiográfico significaría el final de su frágil relación sentimental. Por último, apela a los sentimientos de Cepeda, con la siguiente frase de despedida: "estando tantos días como posible me sea sin verle". Proponer un distanciamiento no era su idea original, pero se la apropia. Recuérdese que lo que motivó la escritura de esta carta era descubrir el por qué del alejamiento de Cepeda, pero concluye apropiándose de la idea que acaba de combatir. Apropiarse del deseo del otro por medio de redefinirlo es su último recurso persuasivo. No obstante, esos mecanismos de seducción no la hacen olvidar el propósito ulterior de su proyecto autobiográfico: la confirmación de una entidad en base a la conciencia rememorativa y la experiencia del yo.

De acuerdo con Selimov, los abruptos cambios de tono tan frecuentes en las cartas de Avellaneda marca dos tipos de discursos, el que usa para tratar con el presente, y el que usa para recrear un personaje "que adquiere significación propia, de ente de ficción" (28). Si explicamos estas variaciones como consecuencia de su discurso romántico, concluiríamos con Selimov que la poetisa entra y sale de su "personaje" (61, nota 27). Pero si analizamos esos giros sorpresivos desde la perspectiva que aquí enfocamos, es decir, de las estrategias de poder, tales giros son recursos estilísticos en función de la persuasión, modalidades discursivas que Avellaneda misma admite en concepto: "la verdad es una en su esencia y múltiple en sus formas" (157). Su propósito es que estos giros sorpresivos y voces contrastantes mantengan al lector en perpetuo asombro, que lo reorienten y lo enfoquen en el sujeto que escribe. ${ }^{33}$ Avellaneda evita convertirse en el

\footnotetext{
${ }^{33}$ Por ejemplo, Avellaneda usa giros similares al concluir algunas de sus cartas con la siguiente queja: "Mi pluma es tan mala, que no sé si entenderás ésta" (153). Este mecanismo recurrente parece ser un recurso
} 
estereotipo femenino que, según Cixous, la literatura había fomentado: “¿Soy yo ese nocuerpo vestido, envuelto en velos, $[\ldots]$ mantenido al margen de la escena $[\ldots]$ muñeca fantasma...? (22). Su determinación es no regresar a la posición subordinada del discurso femenino que no era escuchado.

Con relación a lo anterior, Evelyn Picon Garfield explica: “Avellaneda disloca el discurso hegemónico, rompiendo con la representación tradicional de la mujer. Es más: renuncia los signos que le han atribuido para idear su propia identidad sin saber cómo pormenorizar una alteridad todavía irreconocible e innombrada por el discurso hegemónico, paralizado ante la dicotomía de lo femenino y lo masculino" (47). Aunque le ocupaba otro asunto, era inevitable que en el proceso de la escritura de esta carta, Avellaneda se enfrentara ante sí misma: el que escribe es el primer receptor de su propio relato (Kristeva, Language 8). Dentro del contexto epistolar, Pedro Salinas explica la misma idea, al escribir que una "carta se dirige primero a nosotros" (36). Ella misma comprendía el efecto que la escritura ejerce sobre el emisor: “¿pero adónde voy a parar con estas reflexiones?... Para probarme a mí misma [...]" (146). En esta carta, la escritora decidía entre lamentar el desamor o confrontar la pérdida, una entre las múltiples decisiones que, carta tras carta, terminarían por definirla.

Aunque la intensidad de las cartas de Avellaneda no disminuyó a causa de la incomprensión de su interlocutor, en la Carta XLII de 1847, ocho años después de su primera misiva, acudimos a la desmitificación de Cepeda como "ministro del cielo": "Yo no quiero ni tu amor ni tu amistad, si no puedes darme uno u otra tan grande y tan noble

metafórico para expresar su frustración ante la impotencia del lenguaje, o hacia la incomprensión de Cepeda. 
como yo los necesito, y dale el nombre que quieras". Avellaneda se acogía a un antidiscurso que él no era capaz de reconocer. Escribiendo cartas propiciaba la creación de nuevos espacios para el discurso femenino, es decir, posibilidades de escritura y de auto-representación. Aunque sus cartas perdieron el carácter confesional del principio, habían servido para fijar una identidad que transgredía los modelos de escritura epistolar femenina. Cepeda, como parte de la cultura patriarcal, observaba con consternación aquella enérgica imagen que brotaba de esas cartas. Paradójicamente, como interlocutor de aquel epistolario, Cepeda contribuyó al desarrollo del mito lírico de identidad que trató inútilmente de silenciar.

Al poner por escrito los hechos de su vida, Avellaneda lograba fijarse e inscribirse en la consciencia del lector, por medio de primero explicarse a sí misma. Tanto en su imagen pública como privada terminó por trascender su reputación como la nueva escritora decimonónica que se hacía escuchar. ${ }^{34}$ La intensidad de la entidad que formó a partir de su autobiografía la convirtió en una de las figuras míticas de la cultura cubana.

\section{Avellaneda frente a la sociedad: organización y desarrollo de las ideas como mecanismo de persuasión. ("Cartas a Ignacio Cepeda," VI).}

La compleja relación sentimental de Avellaneda con Cepeda la obliga a enviarle la Carta VI, con fecha del 28 de agosto de 1839. Él se sentía intimidado ante la pasión con la que "Tula" le escribía. Su lenguaje pasional no coincidía con el ideal hegemónico femenino. Avellaneda, por su parte, se debatía ante la disyuntiva ideológica que describe

\footnotetext{
${ }^{34}$ Ver el artículo "Galería de poetisas españolas contemporáneas" de Carolina Coronado. En este artíuculo, la escritora reacciona a la decisión de un crítico de llamar a la Avellaneda "poeta" y no "poetisa".

Coronado escribe: "Después de tantos siglos de esperar la aparición de un astro donde la luz de Safo se reflejase, cuando del centro del océano aparece vivo, reluciente, espléndido, radioso ¿nos lo quieren quitar de nuestro cielo?" (en Caballé 449).
} 
en la misma: “ ¡La necesidad de independencia y el temor de la opinión, que me impide proporcionármela". Aunque el romanticismo era el movimiento cultural que proclamaba el espíritu de independencia y libertad, aquella sociedad no estaba preparada para aceptar que la mujer se uniera a tal iniciativa. A las románticas les preocupaba el dilema que surgía en torno a la subjetividad femenina y los prejuicios sociales (Kirkpatrick 271). De manera que para el tiempo de escribir esta carta, Avellaneda se enfrentaba en lo personal y en lo profesional a la sociedad peninsular decimonónica.

El propósito de la Carta VI era calmar las dudas de Cepeda sobre la naturaleza de sus sentimientos: la sincera amistad que sentía por él no debía confundirse con la distorsionada imagen que la sociedad tenía del amor. Al ilustrar su argumento, la escritora reflexiona sobre ciertos comportamientos sociales, por lo que el tema de su carta se ocupa de lo particular y también de lo general. La carta coincide con el momento en el que la mujer se incorporaba a la literatura con una variedad de temas y formas, como lo eran el teatro, el ensayo y los métodos pedagógicos. A partir de tales formas, opinaba sobre temas polémicos como la esclavitud, las diferencias sociales y el matrimonio sin amor. Avellaneda pertenecía a la línea más radical de aquellas escritoras (Prado 27). Es por eso que observaba con recelo una sociedad que promovía el matrimonio sin amor y amañado a intereses ulteriores. Aquí proponía al amor y no a la sociedad como el camino hacia la felicidad, la verdad y la belleza. Ahora, desde una perspectiva íntima, se dirigía a un individuo que sufría el mal du siècle, por lo que sabía que el choque entre las actitudes sociales y los sentimientos individuales era tema de su interés. El rasgo distintivo de esta carta es la organización y el desarrollo de las ideas como recurso y mecanismo de persuasión. 
Distribuida en 15 párrafos (saludo, transición de la estructura epistolar a la presentación del tema o exordio, argumentación, resumen o síntesis, regreso al formato epistolar, despedida y posdata), la carta sigue el protocolo epistolar. Avellaneda la introduce escribiendo sobre sus compromisos profesionales. Cuenta que su novela $S a b$ le había granjeado los "elogios inmerecidos", de un "hombre instruido y de gusto" quien alentaba su "tímida pluma". En esta novela denunciaba la condición abyecta del esclavo en Cuba, además de la posición subalterna de la mujer, condición que aquejaba tanto a la sociedad cubana como a la peninsular. Para este tiempo, Avellaneda también escribía artículos y novelas que trataban sobre la realidad social y las libertades individuales.

La carta continúa con unas cuantas frases de transición para introducir el tema que le preocupa: "le hablo de cosas que no son más que cosas; $[\ldots]$ evito un lenguaje, que usted llama de la imaginación [...] le juzga peligroso y le destierra de nuestras cartas.” Cepeda sabía que estar "poseído [tal vez por el amor de una mujer] no es deseable para un imaginario masculino" (Cixous 46). Su petición requería que la escritora revisara el lenguaje de sus cartas, por lo que ella ahora intenta buscar una forma epistolar intermedia, a medio camino entre la conquista amorosa y el proceso dialéctico. De manera que Avellaneda cree oportuno solidarizarse inicialmente con su petición: "Yo suscribo a su formidable sentencia [...]". Esta era una estrategia recurrente en el epistolario de Avellaneda, es decir, "someterse a la sentencia de su lector para, desde allí, desarticularla y transgredirla [...]" (Pagés-Rangel 139). A partir de este punto, la escritora comienza a desarticular la petición de Cepeda, valiéndose de la lógica del 
lenguaje. La escritora le propone un diálogo virtual, e invita a su lector a participar del proceso. $^{35}$

A partir de 1830, el romanticismo se había convertido en el movimiento cultural que en España alteró las representaciones del yo (Kirkpatrick 47). Tal renovación cultural propició la necesidad de razonar y opinar, actividad que documentó la prensa del siglo XIX con la publicación de una diversidad de ensayos. El ensayo era además "una obra de arte, donde el subjetivismo en la selección e interpretación de las ideas es algo esencial", un "paseo intelectual”, para algunos (Gómez-Martínez 65, 100). A menudo el ensayo recurría al formato epistolar como marco al que subordinaba su contenido. Avellaneda se había formado en el ensayo y la epístola de Rousseau, por ejemplo, a quien se atribuyen 2,700 cartas; o en Montaigne, padre del ensayo moderno, cuya biblioteca contenía más de 100 epistolarios. ${ }^{36}$ Imbuida de tal espíritu, no es de extrañar que en su carta siguiera un proceso similar de persuasión, organizando las ideas y dialogando virtualmente con el lector.

Luego de escribir sobre sus éxitos profesionales, Avellaneda introduce el tema que la ocupa por medio de preguntas guiadoras: "pero ¿qué temes tú, amigo mío? ¿qué peligro quieres evitar? [...] ¿temerás sentir o inspirar un sentimiento más vivo que el de la amistad...[...] tranquilízate, yo te aseguro que no me amarás nunca sino como a tu hermana". Su propósito era demostrar que el amor de aquella sociedad había perdido su

\footnotetext{
${ }^{35}$ Sobre la conexión de la epístola con otros géneros literarios, ver Actas de las III Jornadas de Humanidades Clásicas. Almendralejo. Febrero de 2001: "Retórica epistolar: de la carta a la autobiografía, el ensayo y la novela. Pedro Martín Baños.

${ }^{36}$ Sobre la influencia de la obra de Rousseau en la mujer, Emilia Pardo Bazán escribe en La cuestión palpitante: "Rousseau ejerció sobre su época el decisivo influjo que alcanzan los escritores si aciertan a erigirse en moralistas. Las mujeres lo idolatraron [...]."
} 
verdadero significado, y que no era el sentimiento que Cepeda temía "sentir o inspirar". Nótese que la escritora se vale de los recursos del lenguaje, por ejemplo, en el uso de la perífrasis para representar un sentimiento. "Un sentimiento más vivo que la amistad" reemplaza a aquel "amor" venido a menos. Se vale además de los adverbios "nunca" y “jamás”, aunque éstos son garantías falsas por su connotación futura. Con esta manipulación del lenguaje Avellaneda intenta sosegar al lector que teme sentirse atado por "lazos de hierro".

El discurso del poder tanto existencial como espiritual que Cepeda reconocía se regía por las autoridades supremas de Dios, el rey y el padre. Ese era el discurso autorizado. Las producciones de la época demuestran la incertidumbre de las escritoras en cuanto a expresarse bajo un sistema de autoridades (Picon Garfield 11). El hombre controlaba el comportamiento y el futuro de la mujer y no ésta a aquél. Pero surgieron mujeres, como Gómez de Avellaneda, que "recurrieron a la autoridad de su propia subjetividad para producir imágenes del yo" (Kirkpatrick 67). No obstante, al inicio de esta carta, Avellaneda renuncia a tal discurso autoritativo y se vale de digresiones y de subterfugios del lenguaje para explicar la naturaleza de sus sentimientos.

Para ilustrar su argumento, la escritora pasa a criticar ciertos modelos de comportamiento social. Es aquí donde llama "cáfila de aduladores que asedian a nuestro sexo" a los individuos que en aquella sociedad profesaban un amor falso:

¡Amantes!...[...]¡Ni puedo creer que me amen! Uno me obsequia porque soy una forastera que no conoce, cuya clase acaso juzga dudosa, cuyas costumbres ignora y acaso puedan 
ser fáciles, cuya conquista no le parecerá dudosa, y me obsequia creyendo que puedo ser su capricho, su juguete, su pasatiempo, su placer de algunos días. [...] Otro me obsequia, porque hace profesión de obsequiante de cuantas mujeres bien parecidas se le presentan: sin ideas, sin cálculos, sin esperanzas, sólo por el prurito de galantear y hacer de elegante. Otro me obsequia, porque $[\ldots]$. Soy americana, y por ser americana supone que soy rica, [...]. En fin, otro me hace el amor [me corteja] sólo por vanidad $[\ldots]$ porque cree darse importancia en la sociedad $[\ldots]$.

Obsérvese que Avellaneda anula las entidades y generaliza la actitud de esos individuos. Omite además detalles particulares que pudieran restar peso a su argumento y lo redujeran a recuentos anecdóticos. Sin embargo, durante ese proceso reflexiona sobre la actitud de la sociedad hacia la mujer, hacia el extranjero, hacia el dinero. Así, sintetiza comportamientos en arquetipos sociales y descubre lo general en lo particular. Las incidencias de tales actitudes convertían esos comportamientos en males sociales extendidos: "asedian a nuestro sexo", "profesión de obsequiante". El juicio colectivo se nublaba ante lo desconocido, y allí era en donde surgía el prejuicio.

A continuación, Avellaneda añade: "He aquí, querido Cepeda, los motivos que impulsan a la mayor parte de aquellos que me hacen la corte. Y estando yo en esta persuasión, podré oírlos con otro objeto que el de burlarme de ellos?” Es interesante notar la actitud de donjuanismo femenino de la escritora en ese pasaje. Su actitud usurpa el papel que tradicionalmente pertenecía al hombre en la sociedad y en la literatura, el de 
la conquista amorosa. Avellaneda se apropia de tal papel y transgrede, aun sabiendo que tal posición tiene un costo social: "el temor de la opinión, [...]!" La escritora se burla de la actitud de aquellos hombres desde su posición individual. Pero además, al reunirlos bajo un mismo criterio, opina desde la perspectiva del observador crítico sobre un mal generalizado.

Si bien la actitud social del hombre era reprensible, la de la mujer social era igualmente indeseable. Obsérvese a continuación, su crítica en torno a la actitud social de la mujer:

¿Y usted qué hallará en las mujeres que digan amarle?

Una dice que le ama, y no ama más que su colocación. Desea un marido, un estado, que es la ambición de las mujeres vulgares, [...]. Otra dice amarle, y sólo ama en usted a su pasatiempo, $[\ldots]$ y al que dejaría sin pesar por otro más galán, de más representación social, [...]. Otra dice amarle, y sólo ama en usted sus propios placeres, y...joh!, rubor causa decirlo, pero lo vemos cada día para vergüenza nuestra; vemos esta clase de mujeres que degradan la dignidad de su sexo, y son a mis ojos más despreciables que la escoria más vil de la tierra.

¡Y tal es el amor en nuestra triste y corrompida sociedad!

Durante el período romántico, las costumbres urbanas permitían que la mujer se desplazara por la ciudad y compartiera con hombres en sociedad. Aunque este comportamiento existía dentro de las clases sociales superiores, todavía la subjetividad femenina se reducía a su papel doméstico. Compartir en sociedad no le daba el derecho a 
opinar ni a disentir, por lo que algunas mujeres adoptaban una actitud indiferente y frívola.

Gómez de Avellaneda era una abanderada en la búsqueda de una voz alternativa de doble alteridad. Como extranjera y como mujer, primero se distanciaba del centro, desafiando la hegemonía del poder, y luego subvertía el discurso hegemónico que intentaba definir a la mujer: le negaba su "poder totalizador", como Sujeto definidor" (Picon Garfield 10). La escritora critica la actitud de la mujer social, por lo que se apropia del derecho a la definición como punto de referencia de la crítica. Esta era una posición delicada teniendo en cuenta que aquel era el momento en el que la escritora decimonónica defendía sus derechos sociales y profesionales. Pero Avellaneda propone un asunto aún más trascendental, que encontraría réplicas similares dentro de diferentes contextos: la actitud de la mujer contribuía a su propio determinismo social. Este contra discurso movía las bases de los argumentos de las primeras escritoras que protestaban la posición subalterna de la mujer.

Avellaneda encuentra en su carta la ocasión de poner distancia con la actitud de aquel arquetipo social. Algunas mujeres comprometían su esencia femenina (lo atemporal y eterno), para estar a la altura de una sociedad corrompida (lo inmediato y fugaz). El destino social de la mujer no sólo era un asunto de un cambio en los modelos hegemónicos, sino de un replanteamiento de actitudes y conceptos para ambos sexos. Esta idea la retoma en un ensayo costumbrista que publica en 1843. En "La dama de gran tono" describe el papel de la mujer basándose en su propia observación. En él reflexiona y contrasta la actitud de la mujer dentro y fuera de la sociedad: la mujer social es un artificio o máscara que se pone la mujer natural (la madre, la esposa, la hija, la 
amiga) para sobrevivir dentro de su entorno. Con esa visión vanguardista, la mujer intentaba "rescatar su naturaleza sin saber lo que les era postizo y lo que era en ellas natural" (Prado 17). Años más tarde, se quejaría de ser "lastimada de continuo por esas punzadas de alfiler con que se venga la envidiosa turba de mujeres envilecidas por la esclavitud social" (Carta XXXI). La carta en cuestión era un ejercicio literario de lo que luego desarrollaría en sus ensayos sobre el destino social de la mujer.

Cepeda debió haber estado familiarizado con los ensayos de Avellaneda, porque en abril de 1840 ella le cuenta sobre el "éxito tan brillante" que tenía en ese género (“Cartas a Ignacio Cepeda,” XXII). Además, en aquellas cartas la escritora opinaba sobre la actitud ante la vida y el mal del fin de siglo; el abuso de poder del hombre sobre la mujer; el matrimonio y el ideal femenino; la relación entre la felicidad y la fe; entre la amistad y el amor; la futilidad de la vida; la naturaleza humana y la corrupción política; la relatividad de la libertad humana; el amor carnal y el espiritual y muchos otros temas más. A menudo, lo que debía haber sido una carta de amor se transformaba en atinadas digresiones filosóficas, temas poco frecuentados por las escritoras de su época. ${ }^{37}$

Avellaneda continúa su carta dirigiéndose sutilmente hacia tema que la ocupa: “ $¡ Y$ tal es el amor en nuestra triste y corrompida sociedad! ¿Cómo podía él existir entre nosotros? [...] Temerás cuando yo no temo?". Tula intenta abordar el tema de su carta de manera tangencial. Nótese que la forma verbal para la segunda persona implica probabilidad ("temerás"), mientras que para la primera implica certeza ("no temo"). Nada de lo escrito anteriormente había sido el verdadero enunciado de su carta. La escritora había montado sus razonamientos sobre digresiones y premisas falsas, y había

\footnotetext{
${ }^{37}$ Compárese lo anterior con las Cartas I, XIV, XXXII, XXXVII, XLII, LII, IX, XI y XI.
} 
sabido aguardar: "temes los lazos de hierro, que pudieran ser consecuencia de tu amor por mí, y crees evitar algo acogiéndote a la sagrada sombra de la amistad. [...] que la amistad señalaría límites que el corazón respetara!”. Este era el epicentro de su drama sentimental: Cepeda teme amarla.

En el pasaje anterior, la primera persona asume un papel activo y reitera su presencia con el uso redundante de los pronombres: "temes que me posesione yo de tu corazón". En otros pasajes también había usado formas similares, "tranquilizándote a ti"; "pero no imitaré yo [...]”; “¿temerás tú”. Pagés-Rangel ha notado en estas reiteraciones "una conciencia de la fragilidad de las palabras" (135). Avellaneda suple esa carencia con la redundancia, lo que sólo sirve para probar el mundo de contradicciones e incertidumbre de su drama sentimental. Convergían en esta carta ideas encontradas, porque intentaba encontrar el centro entre ser a la vez sujeto y objeto en su relación sentimental, ante la pasividad sentimental de su interlocutor. Además, todas esas contradicciones se articulaban en la voz del sujeto romántico, a cuyo discurso la mujer trataba de incorporarse. Sus conflictos repercutían en su obra pública, porque en ella aparecen contradicciones "socio-ideológicas, que no se excluyen sino que se cruzan" (Picon Garfield 10).

Aparentemente cansada de merodear el propósito de su carta, Tula aborda el tema que le preocupa de manera directa:

temes los lazos de hierro, que pudieran ser consecuencia de tu amor por mí, y crees evitar algo acogiéndote a la sagrada sombra de la amistad. [...] ¡Cuánto te engañas, querido, cuánto, si crees que la amistad señalaría límites que el corazón 
respetara! ¿Qué importa el nombre a los sentimientos? ¿Dejan de ser los mismos?"

Ya era hora de que Cepeda reconociera la naturaleza de sus sentimientos, a los que en último caso no era necesario ni siquiera darles nombre. Aquel inocente sentimiento disfrazado de amistad debía sucumbir ante los asedios del amor. Avellaneda nuevamente había recurrido a un juego de palabras cómplices para razonar con su lector. En una carta anterior, la Carta III, llamaba también "amor disfrazado" a aquella alegada amistad.

No obstante, la escritora recurre a un último recurso persuasivo antes de concluir: "Raro, original es el papel que hago contigo. Yo, mujer, tranquilizándote a ti del miedo de amarme. ¡Es cosa peregrina! Pero contigo no soy mujer, no; soy toda espíritu, y ninguna regla es aplicable a es te cariño excepcional que me inspiras". La escritora por fin pone nombre al sentimiento que los une, y esto lo hace con el tono sosegado del pasaje anterior. La lentitud de la frase contrasta con la energía anterior de su carta. "Amar" se coloca a una distancia prudencial de la segunda persona, "tranquilizándote a ti del miedo de amarme", y el "yo" epistolar (representado por la forma morfológica en "amarme") encubre la acción de amar. Por su sencillez y elegancia, palabras aparentemente inocentes componen una de las más efectivas estrategias en el poder de la persuasión. Parece que la escritora celebrase una victoria pírrica que la deja falsamente sosegada.

Al escribir "Yo, mujer", Avellaneda demuestra estar consciente de que usurpa el papel tradicional del protocolo en la conquista amorosa y en la representación del sujeto femenino. Sabía que no sólo era juzgada por la sociedad, sino también por otras escritoras que no aceptaban su manera de expresarse, y no concebían a la mujer alejada 
del discurso hegemónico autorizado. Compárese, por ejemplo, con la opinión de Fernán Caballero (Cecilia Böhl de Faber): "He aquí por qué la mujer masculina, que se gobierna por sí, que no reposa sobre otro, es un ser que repugna" (en Caballé 227). Con el "Yo mujer", Tula sabe que rompe con los límites autorizados para el discurso femenino, además de que impugna la tradición que gobernaba las relaciones entre mujer y hombre (Picon Garfield 33). Pero era ya necesario que Cepeda admitiera la naturaleza de sus sentimientos. Si tenía miedo de amarla, sería porque el amor ya era parte de una premisa, era una condición preexistente que debía aceptar.

"Nada nuevo ocurre en Sevilla". Con este giro sorpresivo la escritora abandona el tema que la ocupa, lo que debió de tomado por asalto al lector. No obstante, la gravedad del tema reaparece en la posdata: "Ruego a usted disimule la incoherencia de ésta, y su poca unidad y defecto de estilo. Veo que está rara; pero va según mi cabeza. ¡Tengo tanta confusión en ella!". Avellaneda sigue el protocolo epistolar, al solicitar la benevolencia del lector. Sin embargo, al observar la manera en la que desarrolló sus argumentos, estas frases no pueden menos que aparecer como un fingido desconcierto. ${ }^{38}$ Tales formalidades son parte de las técnicas de autentificación, además de que el afán de estilo surge a propósito de la preocupación por ser creído. Todo era parte de la "retórica del simulacro" con la que las mujeres manejaban "dos verdades" al escribir cartas (Arriaga Flórez, "Epistolario" 9).

La estructura tri-partita de la carta en cuestión (introducción sosegada, argumento apasionado y conclusión que restablece la paz epistolar) presenta el equilibrio estructural

\footnotetext{
${ }^{38}$ La tradición pre-romántica de la epístola se ilustra en un pasaje similar en la novela epistolar de Laclos: "[...] this language which, through the way it is abused today, [...] It has come to be a simple formula in which one cannot believe, any more than one believes in 'your very humble servant"' (294).
} 
de la escritura avellanedina. Del equilibrio de su compostura expresiva se ha dicho: "gracias a la conciencia de su arte todo este borbotar sentimental de su ser no se hizo sensiblería sino elegante estilización. [...] no descompone su figura, aunque se le desgarre el corazón". ${ }^{39}$ Su cuidadosa compostura epistolar se advierte, por ejemplo, en la vacilación del trato de la segunda persona, es decir, entre el "tú" y el "usted". Esto se hace aún más notorio cuando esa vacilación se presenta dentro de una misma oración: "Yo suscribo a su formidable sentencia, pero ¿qué temes tú, amigo mío?" Tal vez la escritora experimentara un choque cultural o un temor desmedido a errar en el trato que le debía al interlocutor. En cualquier caso, Avellaneda demuestra una elegancia de estilo que coincide con el lenguaje del ensayo, en donde la preocupación estética es parte integral de las técnicas de persuasión.

Para el tiempo de la escritura de la carta en cuestión, Avellaneda se enfrentaba a la sociedad decimonónica, por lo que en muchas de sus misivas abordaba temas de interés general. Cepeda, como lector, percibía que por la variedad de temas y por la manera de desarrollarlos, las cartas de Gómez de Avellaneda podían apelar a un público más amplio. Es así que debió de haberle sugerido una posible publicación porque, con fecha de 26 de marzo de 1854, Avellaneda le responde: "respecto a lo que me consultas sobre mis cartas, [...]. Ignoro si hay en esas cartas confidenciales cosas que puedan interesar al público, [...]" (I, 171). No es posible imaginar que deseara publicar estas diatribas pasionales, en las que se le calificaba de sujeto apático, incapaz de amar. Y sin embargo, Cepeda disfrutaba de aquella lectura. En cuanto a la paradójica conexión del lector con su texto, Roland Barthes ha hecho la siguiente observación: "quién sería capaz

\footnotetext{
${ }^{39}$ Literatura Hispanoamericana, Anderson Imbert/Florit. Tomo I, pág. 313.
} 
de soportar la contradicción sin vergüenza? Sin embargo este contra-héroe existe: es el lector del texto en el momento en que toma su placer" (10). Aunque no correspondió al amor de Avellaneda, Cepeda encontró en la lectura de aquellas cartas un goce inusitado. Es así que finalmente las hizo publicar en 1907, en cumplimiento de su deseo póstumo. ${ }^{40}$

\section{Avellaneda frente al amor: el discurso del sujeto romántico. "Cartas a Ignacio Cepeda," XXXVIII.}

Entre 1839 y 1840, Gertrudis Gómez de Avellaneda mantuvo una precaria relación sentimental con Ignacio Cepeda. Ella escribía, "no deseo más; yo renuncio a toda otra felicidad" (107). Pero él se sentía asfixiado por una mujer que no comprendía. La escritora por su parte estaba imbuida por la pasión del amor romántico, el estado emocional que aspira a la plenitud, la entrega total del sujeto al sentimiento: "Ámame o mátame" (109). Para el 21 de abril de 1840, la relación entre ambos era insostenible. Él se quejaba "Tú has amargado mi destino", y las cartas de Avellaneda se reducían a informes sobre su vida profesional, con algunas alusiones al tema del amor.

Los años que sucedieron entre 1840 y 1846 representaron una etapa fecunda en la obra literaria de Gómez de Avellaneda. Estrena su primer drama Leoncia (1840), y escribe sus novelas $S a b$ (1841), Dos mujeres ${ }^{41}$ (1842) y Guatimozín (1845). Consolida su prestigio profesional y social, y participa en las tertulias de intelectuales y de las mejores familias de su época. De la tempestuosa relación con el poeta Gabriel García Tassara entre 1844 y 1845, concebía la hija que murió poco después de nacer. Avellaneda reanuda su correspondencia con Cepeda en 1847, luego del matrimonio y de

\footnotetext{
${ }^{40}$ En 1914 se publica una segunda edición del epistolario que contenía cartas que habían censuradas de la edición de 1907. En 1975 se publica el segundo epistolario de Avellaneda.

${ }^{41}$ Dos mugeres, de acuerdo con la grafía de la primera edición.
} 
la muerte en 1846 de su primer esposo, Pedro Sabater. En el entorno político, Isabel II gobierna en medio de corrupción electoral y pronunciamientos militares, y España se adentra en el segundo período de las guerras carlistas.

Aunque la conducta misógina de Cepeda coincidía con el ideal romántico con el que Avellaneda se identificaba, estaba claro que la manera en la que ambos concebían amor estaba en conflicto. En el romanticismo, el amor era el camino hacia el conocimiento, el arte y la belleza. Sin embargo, el papel de la mujer dentro de la relación amorosa se reducía a modelos de comportamiento y polaridades maniqueístas. La mujer era para el hombre o su redención o su perdición, inalcanzable o caída, pero nunca a su misma estatura como individuo. Avellaneda toma nota de la capacidad humana (tanto del hombre como de la mujer) de concebir y reaccionar ante la experiencia del amor. Parecía evidente en las cartas su insatisfacción por la tibieza sentimental de Cepeda, pero también su inconformidad con el ideal romántico para la mujer. Bajo tales coordenadas, la escritora reflexionaba sobre el amor como el gran sentimiento del ser.

Si las cartas de Avellaneda contenían contradicciones existenciales, las de Cepeda debieron de haber sido igualmente contradictorias. El sentimiento de atracción y rechazo que él sentía no podía menos que repercutir en las respuestas que ella le enviaba. La Carta XXXVIII, del miércoles 6 de octubre de 1847, viene como respuesta a la queja de Cepeda de que ella lo cree de poco valor. Él pensaba que la tibieza sentimental que la escritora le atribuía implicaba además una debilidad moral. Por otra parte, ya que parecía disfrutar de aquella lectura epistolar, tal vez estuviera proponiendo posibles temas de escritura. Fuera como fuere, Avellaneda responde a su queja: "Dices que haciéndote 
entender que me pareces de poco valer no espera yo jamás que tu deduzcas la consecuencia de que te quiero".

Luego introducir su tema, la carta de Avellaneda lee así:

¿Qué es el afecto que no se funda en la estimación? [...] Yo, es verdad, te he dicho, más o menos acaloradamente, que no hallaba en tu corazón aquel grado de calor en los afectos que el mío siente y busca en los corazones que ama; te he dicho (no sé si con justicia, pero si sé que con indicios claros de no ser absurda mi creencia), que no posees una de aquellas almas expansivas y tiernas, que simpatizan con todos lo ajenos pesares, adivinan todos los combates y borrascas del sentimiento y suavizan con su ternura activa y férvida las mismas pasiones que excitan. ${ }^{42}$

A sólo 14 años de la definitiva implantación del romanticismo en España tras la muerte de Fernando VII, el concepto del amor se transformaba, tal vez para sorpresa de Cepeda. El amor romántico al que apela Avellaneda era un valor trascendental, un sentimiento totalizador y única vía del individuo para comprender el mundo. Era un principio divino, uno de sus más elevados valores, con el que el hombre veía acrecentar su sed del infinito. Kierkegaard explicaba que "romantic precisely means that it oversteps all bounds" (en Peyre 113). El romanticismo era también plenitud, camino hacia la trascendencia y la espiritualidad. Sin él, la vida era muerte, y morir por amor, vida.

\footnotetext{
${ }^{42}$ Obsérvese el paralelo del pasaje anterior con la descripción que da de sí misma la heroína de la novela, Catalina, alter ego de Avellaneda: "Entonces es preciso ser guerrero o político: es preciso crearse un combate, una victoria, una ruina" (II, 110). La similitud de ambos pasajes es evidente, tanto en concepto como en lenguaje.
} 
Aunque ya en la obra de Leandro Fernández de Moratín se defendía la idea del matrimonio por amor, el amor romántico rompía con los modelos anteriores que regían las relaciones humanas, por lo que el yo apasionado desafiaba a la razón, al orden y la mesura. No obstante, Cepeda no poseía una de "aquellas almas expansivas."

En el pasaje anterior se trata al amor como un sentimiento superior, perteneciente a la categoría de los valores humanos de quienes les preocupa la felicidad ajena. La función principal del lenguaje romántico, así como aquí se muestra, era conmover, hacer al lector parte de la experiencia romántica que embarga al escritor. Pero además de esto, y siguiendo su estilo epistolar, Avellaneda responde al argumento de Cepeda acogiéndose al tema del amor desde una dimensión más amplia. Es así que eleva el tema de su carta para entonces debatirlo con la gravedad de los temas universales. Su crítica se acoge a una voz en gran medida distante, en la que se percibe una autoridad epistolar superior.

Obsérvese que la escritora opta por no identificarse con el sujeto que sufre los "combates y borrascas del sentimiento" que el interlocutor no es capaz de adivinar. De esa manera establece que la carencia sentimental de aquél transciende la relación de ambos. Esta propuesta le sirve de preámbulo al perfil moral que realiza a continuación: "He creído, y lo he dicho con mi natural veracidad, que eres más sentimental que sensible profundamente, más amable que amante; que tienes más bondad que pasión y menos ternura que talento". Aquí la escritora invierte el orden de jerarquías en la relación mujer-hombre: la mujer no había de tener voz propia, mucho menos debía definir al hombre.

El recurso usado por Avellaneda, tradicionalmente funcionaba a la inversa: el hombre definía a la mujer, acto que le permitía limitar sus posibilidades y aspiraciones. 
La mujer debía ser la síntesis del discurso del hombre, nunca ser sujeto, sino objeto de su devoción o de su rencor. El canon estético que la asociaba con la naturaleza dictaba que también fuera su musa. Una mujer con voz propia, como Avellaneda, trastornaba el orden natural y lo transgredía. Reformulaba además el modelo de la carta de amor, porque era la tradición (desde las cartas de Eloísa en la realidad, o Las cartas de una monja portuguesa en la ficción) que el papel de la mujer se limitara a lamentar la indiferencia del amante.

Nótese también que la estrategia de la escritora consiste en llamar la atención a las virtudes del interlocutor para luego anularlas. El rango y la intensidad de las cualidades que propone cancelan la superioridad de las cualidades de Cepeda. Así, el sentimiento compite con la sensibilidad, la amabilidad con el amor, la bondad con la pasión y el talento con la ternura. En este sentido compara la superioridad sentimental del sujeto romántico sobre la de los modelos culturales anteriores. La mesura y el utilitarismo neoclásico debía ceder paso al subjetivismo y la pasión romántica. Avellaneda añade: “¿Es la facultad de amar, por ventura, la sola excelencia del hombre? Tu honradez, tu veracidad, tu clara inteligencia, tu lealtad de alma, tu carácter, frío si se quiere, pero noble y digno son cualidades de poca valía?" Con esa salvedad, la escritora plantea otra idea propia del romanticismo: la ironía.

La ironía encuentra sus raíces en el método dialógico socrático, en el que se presentan dos opiniones opuestas. En el pasaje anterior, la escritora glorifica las cualidades de Cepeda para luego anularlas comparándolas a la superioridad de otras. Tal actitud propicia en ella movimientos de aproximación y alejamiento en relación con el objeto, disposición que se evidencia en su doble evaluación. Esa aproximación irónica es 
necesaria porque impide que el sujeto se anule al contacto con el objeto, aunque a su vez le permite retener su admiración por él: el sujeto puede "sin perder su propia libertad y sin convertirse en esclavo del objeto, compenetrarse con el objeto mismo, manteniendo su propia subjetividad" (Eco 317, 318). Aunque "Tula" estaba resuelta a conquistar el amor de Cepeda, no estaba dispuesta a comprometer su individualidad en esta etapa de su vida. Las direcciones encontradas de atracción y distanciamiento hacia donde la impelen sus sentimientos no logran anular su identidad, como tampoco silenciar el derecho a expresarse por el que había luchado.

La práctica avellanedina de descontextualizar y despersonalizar un problema (¿Es la facultad de amar?"), que de otro modo es inmediato e íntimo, aparece también en su narrativa. Por ejemplo, en 1842 había dramatizado su inestable relación con Cepeda en su novela, Dos mujeres, en donde el personaje de "Carlos" cuestiona el comportamiento de la protagonista. "Catalina", el alter ego de la autora, respondía también descontextualizando la inquietud de su interlocutor acerca de su conducta frívola: ¿Contraen obligaciones con el mundo los que recibieron estos fatales dones del talento y el corazón"? (117). A partir de este punto la autora se vale del diálogo para hablar a través de la voz de la protagonista. Al hacer interactuar las diferentes voces y argumentos del diálogo, logra que el interlocutor finalmente rectifique su opinión. En términos de Bajtín, la pluralidad de las conciencias, la interacción contrastante de las voces, los puntos de vista y los distintos registros del diálogo sirven para sacar a la luz el punto de vista del autor (15). Pero además de una estrategia de su escritura epistolar, Avellaneda se acogía a una filosofía existencial que justificaba su actitud, por encima de los patrones tradicionales de comportamiento. 
Avellaneda ahora pasa a escribir:

[...] siempre te he visto digno de ser amado, aun cuando alguna vez haya creído que tú no sabes amar. Acaso ni aún eso he creído sólo he comprendido que a mí no me amabas. Pero ni tu falta de amor a mí, ni aún la tibieza, que en general pudiera tener tu corazón en la región de las pasiones, es motivo para que yo piense que vales poco.

Parece ser por la lectura de este pasaje que es Cepeda y no Tula quien necesitara una confirmación de identidad. Al decirle "siempre te he visto digno de ser amado" refleja en cierto modo el poder que la opinión de la escritora ejercía sobre él. Además, se apropia del derecho a juzgar su manera de amar: "tú no sabes amar". De cualquier modo, el poder persuasivo que Avellaneda ejerce sobre Cepeda parece ser tal, que él mismo olvida los paradigmas de las relaciones sentimentales, al punto de molestarle la opinión de la escritora: "que yo piense que vales poco".

Con el retrato moral de Cepeda, así como con la caracterización de los personajes de sus novelas, Avellaneda revela su profundo conocimiento de la psicología masculina, lo que la coloca a la vanguardia de otras escritoras del siglo XIX. Por ejemplo, Elaine Showalter, en "Feminine Heroes: The Woman Man", lamenta el desconocimiento de las escritoras inglesas decimonónicas sobre la psicología masculina, quienes se valían de su imaginación para describir las acciones de sus personajes. Algunas terminaban por caracterizarlos a través de su psicología femenina, mientras que otras, optaban por la prudencia y la auto-censura (A Literature 134, 135). Antón Arrufat llama "porosidad de 
la mente" y una "singular comprensión del personaje masculino en contraposición de los femeninos" a ese dominio descriptivo de Gómez de Avellaneda (XXXVI).

A la ignorancia de la novelista decimonónica sobre la psicología masculina, se sumaba una auto-presentación que internalizaba los estereotipos femeninos hegemónicos. Avellaneda cuestiona tal práctica social reflejada en la literatura. Obsérvese a continuación, la auto-representación que rinde en la carta que me ocupa:

Yo misma soy juzgada mal $[\ldots]$ me desconocen, eso es todo.

Dices, además, que te parezco singular, y creo que lo soy por mi mal. No pretendo que mis singularidades sean virtudes; [...]. Ni quiero pasar por mejor de lo que soy, ni siendo lo que soy me hallo descontenta de mi suerte. Sé que hay en mí mucho bueno y mucho malo; que todo el que me conozca debe estimarme como yo me estimo [...]. Estimarme, no como a ser perfecto, no lo soy ni quiero parecerlo. [...] Mis defectos tienen la talla de mis cualidades, y tal cual soy me he presentado a ti.

El romanticismo estaba ligado a la espontaneidad y la autenticidad. Al señalar virtudes y defectos como componentes intrínsecos de su identidad, Avellaneda ilustra otro concepto del ideario romántico: la "relatividad de la belleza" (Eco 307). Su belleza moral correspondía con la de la imagen de la mujer emancipada, ideario que contrastaba con los modelos de pasividad femenina. (Cixous 22). Pero más importante aún, reclama su derecho a la auto-definición, por lo que asumía su propia individualidad: "For all literary artists, of course, self-definition necessarily precedes self-assertion: the creative "I am" cannot be uttered if the "I" knows not what it is" (Gilbert \& Gubar 17). Su auto-crítica 
modelaba una constante de los valores románticos, en donde entraba en juego el valor de la autenticidad de representación.

No obstante su discurso romántico, aquí se nos revela un rasgo innovador del pensamiento avelladiano: la escritora cuestiona el papel femenino en el amor romántico. Ya vimos que la mujer del romanticismo era ángel, pura, siempre feliz, placentera, cándida, bella, vehículo del hombre hacia la espiritualidad. Pero la mujer era también la perdición del hombre, por lo tanto era monstruo. El constructo "mujer" dependía de la voz y del discurso del hombre, para quien ésta era el objeto de su inspiración, idílica o fatal. Esto era a pesar de que el romanticismo proponía la libertad y la individual del sujeto. Pero la auto-representación de Avellaneda subvierte ambas propuestas, no era enteramente buena ni mala. Esta actitud era especialmente importante, tomando en cuenta que para este tiempo las escritoras intentaban incorporarse a la voz de un yo romántico, que sin embargo polarizaba la conducta femenina.

De manera general, la composición de la carta en cuestión depende del contrapunteo entre la subjetividad romántica y la sensibilidad y el utilitarismo neoclásico. En este sentido, se permite lo que califica de "degresión", al comparar el talento de Newton y Napoleón, a la pasión de Tasso, "un alma eminentemente apasionada". 43 Obsérvese lo que Avellaneda escribe a continuación: "poseer lo necesario para hacerse estimar y estar exento de la cruel facultad de amar mucho es un privilegio envidiable que sólo reciben los que nacen para ser felices". Si bien aquéllos se deleitaban en la armonía y la mesura, éstos buscaban el inconmensurable placer de experimentar el dolor. La infelicidad como estética se había puesto en boga con las ideas que partieran del

\footnotetext{
${ }^{43}$ Torquato Tasso (1544-95), poeta italiano del siglo XVI
} 
movimiento alemán "Sturm und Drang" y con la publicación de Las desventuras del joven Werther (1774), novela epistolar de Johan Wolfgang Goethe, precursora del romanticismo. La belleza consistía en el estado de ánimo del individuo, y la infelicidad era su representación (Eco 299). Los seres que aspiraban a la plenitud y a lo infinito encontraban la insatisfacción, por lo tanto sufrían.

A pesar de su retórica romántica, existe en la escritora una voluntad de sobrevivir al pathos romántico. Nótese la síntesis de su argumento en torno a su autojustipreciación: "Estimarme, no como a ser perfecto, no lo soy ni quiero parecerlo. Pero sí como alma elevada [...]". La escritora busca el centro entre dos modelos hegemónicos. No aspira a la perfección y se acepta tal cual es, aunque con ello no alcanzara a representar el ideal femenino. Implicaba además que el auto-reconocimiento y la auto-crítica eran necesarios para que la mujer escapara de los encasillamientos maniqueístas con los que se intentaba definirla. La carta en cuestión concluye con un final abierto: “¿Me amaste tú como soy? ¿Me crees digna?... no lo sé”.

Por segunda vez, Cepeda se desvanecía de la vida de Avellaneda. Tal vez por no someter su individualidad ni a él ni a los modelos culturales, la escritora era una incomprendida dentro de su círculo íntimo, así como por la opinión pública. Adoptaba el discurso romántico como herramienta de trabajo para expresar su cosmovisión en detrimento de las aspiraciones de su interlocutor, así como también para emular algunas de las propuestas del romanticismo como movimiento cultural. Su discurso le servía de "trampolín" para reflexionar o criticar asuntos que tenían que ver con el destino de la mujer (Picon Garfield 120). La carta aquí analizada muestra a una Avellaneda 
identificada con la espontaneidad y autenticidad del sujeto romántico, pero poniendo distancia con el modelo femenino idealizado por el romanticismo.

En la carta XXXVIII Avellaneda implica la idea de que la mujer contribuía a su desventaja personal y social por ser víctima de sus propios sentimientos, además de por depender del juicio ajeno para reconocerse a sí misma. Su pasividad era parte de su propia tragedia sentimental, así como también lo expresa en su novela, Dos mujeres. El auto reconocimiento y la auto-crítica eran tan necesarios para resolver su destino sentimental como lo era defender sus derechos sociales. Tal idea ponía distancia entre su pensamiento y la postura disidente del panfleto feminista, idea que no vacilaba en reflejar en su obra literaria (Arrufat LIV).

La escritura epistolar de Gómez de Avellaneda se inscribía en la mente de Cepeda como el discurso de un sujeto romántico propiamente femenino. Habiendo logrado incorporarse a tal discurso, se vale de él para manifestarse en contra de las representaciones arquetípicas, así como también para reclamar el derecho a la autorepresentación. La carta en cuestión ilustra además que el amor era un derecho humano que se le debía a la mujer, propuesta aún no conquistada ni por el ideal romántico, ni por la disidencia feminista de su tiempo.

\section{Avellaneda ante la pasión y el deseo: el discurso de la mujer emancipada.} “Cartas a Romero Ortiz," XV.

En 1847 cesa la correspondencia amorosa de Tula a Cepeda. Dos cartas posteriores dan fe de la amistad que aún los unía. En su última misiva del 26 de marzo de 1854, le escribe: "Mi corazón, que ha sido tachado de inconsecuente, es, respecto a ti por lo menos, de rara perseverancia”. Los años que siguieron fueron de gran actividad 
profesional para la escritora. Entre 1849 y 1853 estrena siete obras de teatro, en 1851 reedita sus poesías y publica dos nuevas leyendas. A pesar de su éxito literario, en 1853 es rechazada su solicitud de ingreso a la Real Academia Española. Mientras tanto, en la Península se vive la Década Moderada (1844-1854), período de cierta estabilidad caracterizado por una política centralista.

El 22 de marzo de 1853 Avellaneda responde a la carta que recibe de un admirador, Antonio Romero Ortiz (1822-1884), abogado y político progresista, quien le escribe bajo el seudónimo de Armand Carrel. ${ }^{44}$ La naturaleza tal vez osada de Romero Ortiz contrastaba con el carácter frío y distante de Cepeda. Avellaneda, como autor implícito, adoptaba una nueva actitud epistolar ante su nuevo interlocutor. Este es el comienzo de un segundo epistolario que difiere del anterior por su carácter febril, espontáneo, y a veces lúdico. Las cartas a Romero Ortiz coinciden con el período de tiempo en que las escritoras comenzase incorporaban al discurso romántico. Desde la década anterior, las mujeres españolas se afirmaban como escritoras acogiéndose a la ideología de la primera ola de reforma liberal, "precisamente en el momento en el que un nuevo lenguaje para representar al sujeto individual y definir la diferenciación sexual [...]" (Kirkpatrick 11, 12). Sin embargo, no dejaron de surgir contradicciones cuando la mujer intentó ponerse a tono con tal discurso.

El 5 de mayo de 1853, Gómez de Avellaneda envía a Romero Ortiz lo que hoy conocemos como la Carta XV de su segundo epistolario. La carta resulta atípica porque aborda el tema del deseo desde la perspectiva femenina, en un tiempo en el que el ideal

\footnotetext{
${ }^{44}$ Armand Carrel (1800-1836), periodista y revolucionario francés con quien Romero Ortiz se identifica.
} 
romántico proclamaba la asexualidad de la mujer. Su carta viene a propósito de una pregunta de su interlocutor, “¿cómo te amo?”:

El amor, ese tirano insaciable que con nada se da por satisfecho, sabe ser también un niño dócil y hasta pueril, que se entretiene con cualquier cosa, y se alegra y se reputa dichoso. He deseado algunas veces que Armand hubiese continuado siendo por largo tiempo mi invisible caballero; que solo su pensamiento hubiese llegado a mí, siempre envuelto en esas nubes de rosa del misterio, como la eterna promesa de una felicidad nunca poseída pero incesantemente esperada.

Al principio del intercambio epistolar, Avellaneda desconocía la identidad de su interlocutor, pero para el tiempo de escribir esta carta ya mantenían un trato personal. Su actitud epistolar con relación al texto seguía el modelo de sus cartas anteriores. Sin embargo, tal vez sin proponérselo, Avellaneda ilustraba aquí un concepto que tenía que ver con la relación sujeto-objeto dentro de la estética romántica.

Durante el neoclasicismo, lo que se consideraba atractivo y bello estaba condicionado a la armonía y a las proporciones del objeto. La tarea del artista era resaltar sus cualidades. Pero a finales del siglo XVIII comenzó a surgir la idea de que la belleza del objeto residía en la imaginación del sujeto. Las circunstancias particulares en torno a la relación de la escritora con Romero Ortiz venían a propósito para demostrar el valor de tal concepto: "Te amo cuando no te veo, cuando no te escucho, cuando solo llegan a mí tus cartas y no te veo más que en mi corazón. [...] aunque fueras viejo, de fea figura, despreciable para todas las mujeres, serías bello para mí [...]”. Avellaneda, como sujeto 
del enunciado, se siente atraída hacia el objeto por el sentimiento que éste le provocaba, haciendo caso omiso de reglas ideológicas y estéticas. Aunque el nuevo enfoque sobre la relación sujeto/objeto aplicaba al arte, apoyaba en principio el derecho a la subjetividad y la autodeterminación. No obstante, tal concepto no tuvo las mismas repercusiones durante el romanticismo en la vida de la mujer, así como la tuvo en la del hombre.

Luego que Gómez de Avellaneda descubre la identidad de Romero Ortiz, la relación epistolar entre ambos cambia su carácter original. Lo que antes fueran cartas en las que predominaba el juego del ingenio y de la elocuencia, se convertían en misivas de carácter notablemente atrevido. Obsérvese cómo continúa la carta en cuestión:

¡Al adquirir una forma, y un carácter determinado, mi fantástico caballero se ha hecho amar mucho, sí, ciertamente... mucho! pero es indudable que lo que ahora me inspira es un sentimiento agitador y doloroso; mientras todo era dulce, tranquilo, ideal en lo que experimentaba por mi Armand. [...] Te amo entonces con un afecto en que gozo; con un afecto que me engrandece a mis propios ojos.

En contraste con el sentimiento "dulce, tranquilo e ideal", el reconocimiento del deseo producía en la escritora un malestar "agitador y doloroso". Si bien el deseo (nunca satisfecho y siempre anhelante) era el elemento fundamental de la expresión del yo romántico, entraba en conflicto cuando la mujer intentaba incorporarlo a su discurso. ${ }^{45}$ El deseo era incompatible con la identidad femenina, no obstante la libertad y la

\footnotetext{
${ }^{45}$ Para el siglo XIX se había perdido la conexión del amor con la unión de los cuerpos que se diera entre las místicas de la Edad Media Ver "Escritoras de la Edad Media" de Pilar Cabanes Jiménes, en la revista Espéculo. No. 33, de 2006.
} 
independencia que el romanticismo reclamaba para el individuo. La afirmación del deseo de la mujer atentaba contra la estabilidad familiar y social de la cultura burguesa.

No obstante lo anterior, Avellaneda se vale del discurso romántico para expresar sus deseos, aunque para ello era necesario invertir los papeles tradicionales de la carta amorosa. Le tocaba, por lo tanto, asumir el papel activo del sujeto romántico, y convertir a su interlocutor en el objeto de su deseo:

[...] Siento que mi corazón noble y puro se lanza al tuyo por un movimiento de santa confianza y de casta simpatía, y que nos unimos con un vínculo sin nombre $[\ldots]$ entonces no te llamo esposo, porque no encuentro nombre que darte en el lenguaje humano: entonces eres para mí la esperanza, que es el único grande que puede gozar el hombre [...].

Ya que la cultura burguesa promovía una tendencia afeminante que colmaba las expresiones del sentimiento del yo, la mujer debía hacerse un espacio propio al intentar integrarse al modelo de la expresión romántica. La mujer encontraba que era "incapaz de identificarse plenamente ni con el sujeto creador y poético masculino ni con el objeto femenino", aunque ahora se valía de la "autorización romántica" para expresar sus sentimientos (Kirkpatrick 33). Al buscar soluciones a este problema se encaminaba a cuestionar la exclusividad genérica del yo romántico paradigmático. Avellaneda resuelve esta complejidad discursiva en su carta, al hablar con la voz de un sujeto romántico propiamente femenino. Nótese, por ejemplo, que se desprende de la tradicional pasividad del discurso femenino, y se identifica con un sujeto en movimiento que toma la iniciativa de desplazarse hacia el objeto de su deseo: "mi corazón se lanza al tuyo". No obstante, la 
unión que resulta de esta acción, es un "vínculo sin nombre", que no encuentra un apelativo en el "lenguaje humano".

Los primeros románticos encontraron que, al independizar el juicio de los límites prescritos por lo cánones y las reglas, con frecuencia no alcanzaban a precisar la plenitud de sus propios sentimientos. De ahí la sensación de lo vago, lo indefinible, del "no se qué" que Rousseau había acuñado (Eco 303). Tal era el "vínculo sin nombre” que unía a la escritora a su interlocutor. En reconocimiento a tales contradicciones, Avellaneda añade: "entonces respiro contigo una atmósfera tan pura, $[\ldots]$ que me parece imposible la puedan surcar jamás las pasiones terrenales. He aquí como te amo algunas veces; como quisiera siempre: como debo amarte si aspiro a ser feliz por el amor”.

La proximidad física del interlocutor perturbaba la paz idílica hecha de palabras al inicio de su relación con Romero Ortiz. Ante tal nueva situación, nótese cómo la escritora explica lo que para ella significaba tal giro dramático:

Pero desgraciadamente en mi organización desventurada todos los extremos se tocan: cuando te veo, cuanto te oigo, cuando respiro tu aliento, cuando me haces una caricia, me arrancas súbitamente de mi región encantada, me haces desear delicias terrenales, me das fiebre, Antonio. Sí, te amo entonces con pasión pero con cólera contra ti y contra mí, y contra la naturaleza $[\ldots]$.

El reconocimiento del deseo constituía además un acto de rebelión, un atentado contra la naturaleza femenina, por lo que la actitud epistolar de Avellaneda resultaba atípica. Para el sujeto romántico, la mujer era la amada, la naturaleza o la creación poética, 
representaciones que reflejaban la inmovilidad del objeto: lo que era amado, admirado o creado. ${ }^{46}$ La pasión totalizadora y el deseo nunca satisfecho eran irreconciliables y entraban en conflicto con la abnegación que se esperaba de la mujer. Esto era no obstante la libertad que el sujeto romántico reclamaba para sí.

En el pasaje anterior, Avellaneda inicialmente trasfiere su responsabilidad moral a la fuerza ciega con que la naturaleza la conducía a la pasión. Esa visión, típica del saber del siglo XVIII, coincidía con la idea neoclásica en torno al hombre en su estado natural. En el drama de Dos mujeres, Avellaneda justificaba del mismo modo la pasión adulterina de la heroína en nombre del derecho de la mujer natural, la lucha desigual entre la naturaleza y las leyes sociales. Bajo esa línea de pensamiento, Avellaneda continúa:

me pregunto con pavura si es cierto que el hombre está llamado a más alto destino que el que ve en el bruto; si no ha nacido, lo mismo que este, para multiplicarse y morir...me parece entonces que lo que llamamos alma, sentimiento, idea, acaso no son en suma sino seducciones que emplea la pícara naturaleza material para llevarnos ciegos a cumplir sus leyes: esas leyes que el bruto obedece por instinto, y que el animal pensador cumple más fatalmente todavía, arrastrado por la esperanza de un bien mentiroso, irrealizable.

Ahora la escritora se enfoca en el tema del deseo desde la perspectiva humana, y no personal. Su referencia al hombre como animal pensador tal vez se basara en la idea de

\footnotetext{
${ }^{46}$ Véase el capítulo "La autorrepresentación lírica de Carolina Coronado", acerca de los versos de Espronceda a Coronado, en el que recurre a la tradición que identifica a la mujer con la flor como objeto de placer: "Espronceda estaba utilizando un antiguo recursos para poner a la mujer en su sitio, basado en la expresión de un deseo sexual que se suponía que ella tenía que agradecer" (Kirkpatrick 197).
} 
la transformación biológica surgida también durante el siglo XVIII. Con la mirada puesta en la naturaleza, más tarde en el siglo se consideró que la sensibilidad y el sentimiento nacían del contacto del hombre con la naturaleza, no con el artificio. El hombre entonces emprendía un viaje en busca de nuevos paisajes, los que contemplaba volviendo la espalda al observador. ${ }^{47}$ De ahí que el sujeto romántico expresara sus pasiones a través de los fenómenos naturales. De todos modos, el pasaje anterior se distingue porque Avellaneda nuevamente saca el tema que trata del contexto personal. En este caso, iguala al hombre y a la mujer en virtud de su condición humana.

Al opinar desde tal perspectiva, la escritora se apropia de la autoridad de tratar de un tema vedado a la mujer. Con ello abría un espacio de representación femenina, valiéndose de los paradigmas básicos del yo romántico (Kirkpatrick 131). A continuación, Avellaneda confirma su derecho a abordar tales temas, acogiéndose a la autoridad que le concede su condición de poeta. Tal identificación avala y autoriza su discurso:

¡Oh! ¡sí! desgraciadamente hay en mí estas dos naturalezas poderosas del poeta y de la mujer: hay en mí idealismo bastante para vivir toda la vida de un suspiro de tu amor, y bastante sangre para agotar en un momento todo tu amor y el mío. Desgraciadamente también has tenido el poder de despertar a la vez ambas naturalezas, y se empeñan en una lucha cuyo éxito ignoro. En estos momentos en que la victoria se inclina por la

\footnotetext{
${ }^{47}$ Recuérdese las creaciones del pintor Caspar David Friedrich, en particular su obra Caminante en un mar de niebla, de 1818.
} 
naturaleza ideal, entonces es cuando te amo con fe, en ti y en mí; cuando creo que seré feliz y que hallo digna de serlo. En los momentos en que gana terreno la naturaleza terrestre entonces te amo dudando, $[\ldots]$ se revela mi insensato orgullo contra el fallo de mi propia conciencia: entonces sufro, [...].

En contraste con las épocas anteriores, la cultura burguesa de la Europa del siglo XIX había concedido un espacio de poder a la mujer dentro del ámbito familiar. Este protagonismo se le concedía "sólo a costa de que redujeran sus deseos", porque su composición asexual debía garantizar la estabilidad del hogar y de la familia (Kirkpatrick 36). No podía Avellaneda desestimar más claramente tal ideal burgués, pero se enfrentaba a dos luchas ideológicas y morales. Una tenía que ver con su derecho al reconocimiento del deseo, pero otra con los llamados de la consciencia en el ejercicio de su libre albedrío. En este aspecto, la escritora no encontraba representarse con la imagen de un yo unificado.

Una idea similar a la anterior encontramos en la Autobiografía: "Hubiera yo querido mudar mi naturaleza. Creí que sólo sería menos desgraciada cuando lograse no amar a nadie con vehemencia [...]" (74). Se hace evidente la lucha de Avellaneda, y de la escritora en general, entre el reconocimiento del deseo y los límites del modelo hegemónico: "It weaves into language (or other "signifying materials") the complex relations of a subject caught between "nature" and culture, $[\ldots]$ between desire and the law, the body, language, and "metalanguage" (Kristeva 97). Pero le sobrevenía además la preocupación por una naturaleza que flaqueaba ante la pasión, y que se anteponía al 
ejercicio del libre albedrío de su consciencia cristiana. Tal vacilación ontológica era la forma en la que procesaba las contradicciones de asumir su subjetividad femenina.

A Avellaneda le preocupaba un tema más significativo para la mujer que la lucha entre el deseo y la costumbre. Esa era la de la "exploración de la inteligencia, voluntad, pasión y amor propio femeninos" (Picon Garfield 116). Aunque solía pronunciarse a favor de las igualdades civiles y sociales, nunca eximía a la mujer de asumir las consecuencias por su conducta. Esto también formaba parte de la conquista de la libertad del sujeto emancipado. Significaba además un punto de vista axiológico en la formación de la identidad y de las identificaciones colectivas (Zavala, Breve historia I 35). Las contradicciones que surgían entre el deseo y su amor propio se observan en las frases "Te amo dudando", "me desprecio", "mi insensato orgullo", "conciencia" y "sufro". Este era no el contradiscurso en desafío al poder hegemónico, sino su contradiscurso enfrentado ante sí misma, el de las contradicciones en la búsqueda de una representación femenina unificada, sin que para ello contara con modelos en los cuales apoyarse.

La carta continúa de este modo:

Y sin embargo, en medio de aquellas tempestades del alma que se venga tan cruelmente en mí, de los momentáneos triunfos de mi otra naturaleza terrestre, sucede que te amo locamente $[\ldots]$ y me parece en aquel instante que no hay dicha mayor que ser tuya de todos modos; tuya por todos los vínculos posibles.

El reconocimiento del deseo desmentía el mito de la naturaleza asexual de la mujer. Tal mito tenía origen en la interpretación que la Ilustración y Rousseau realizaron sobre el cuerpo femenino (Kirkpatrick 17). Aunque el deseo era el objeto fundamental en el 
discurso del sujeto romántico, el reconocimiento del mismo degradaba la feminidad. Es por eso que la carta de Avellaneda trastornaba el discurso de los sexos y violaba la norma de lo que era aceptable en el discurso de la mujer de su época. De esta manera se convertía en un documento desigual dentro de la tradición epistolar femenina.

El discurso de Gómez de Avellaneda sobre la sexualidad se alimenta de una ética/estética del auto-dominio, con el que expone el ejercicio de la libertad, las formas del poder y el acceso a la verdad "femenina", "ausentes del discurso hegemónico de su época" (Picon Garfield 13). Con relación a lo anterior, nótese la manera en la que continúa su carta:

no querría que me uniesen a ti lazos vulgares, fuese cualquiera su nombre: no querría dar un destino vulgar a este hermoso sueño [...]. Pero otra hora después vuelvo a verte y entonces...entonces digo que solo a Dios se puede amar en $s u$ esencia incomprensible; [...] que mi idealismo es una locura, una profanación... que la felicidad del amor esta en tus brazos y no en mis sueños: entonces, Antonio, quisiera inventar lazos todavía más estrechos que los que conocemos, y más corpóreos, y más sensibles, para ligarme a ti con todos ellos.

Al escribir este pasaje, la escritora rompía "para siempre con los cauces permitidos a la voz femenina", una "moral encendida por igual al hablar del amor que del desamor, del abandono que de la bondad, de la sinceridad que de la traición” (Caballé 33). Si bien el carácter privado de su carta no podía sentar un precedente para el discurso romántico femenino, dejaba un modelo muy claro en el discurso de su alter ego, Catalina en Dos 
mujeres. Con él se inscribía en la mente del lector con un discurso similar. Tal lector podía (re) crear infinitamente su imagen de mujer, de manera que la identidad sexuada femenina era "simbólicamente inscrita en la historia con valor propio - como una presencia imperecedera en nuestra cultura" (Pastor 144).

El drama del yo romántico era por antonomasia el drama del deseo, de lo que el sujeto no poseía ni podía alcanzar (Kirkpatrick 268). Pero al adoptar su discurso, Gómez de Avellaneda reconoce que la libertad del sujeto romántico podía ir en detrimento de su integridad moral. Así, descubría las trampas que asediaban a la mujer tras la máscara de la libertad romántica:

[...] pídeme pruebas a tu placer. No es la primera vez que te he dicho que serás árbitro de mi suerte; te repito ahora que te amaré como tú quieras; que seré para ti, hoy mismo si te place, la que tú quieras que sea; pero déjame creer, amigo mío, Armando mío, mi leal caballero, déjame creer que tú no quieres sino mi felicidad, y que comprendes que mi felicidad será grande si me haces sentir que tú la posees, y que ambos la merecemos.

Poco tiene que ver este pasaje, claramente ausente de inhibiciones, con las presiones sociales ante el reconocimiento del deseo femenino. En la carta del 30 de abril a Romero Ortiz, Avellaneda había escrito: "la libertad verdadera es no esclavizarse a nadie en nada". Pero ahora temía ser esclava de sus propias debilidades. Este era su propio contradiscurso enfrentado a su consciencia y sentido común. El derecho social, cultural y profesional de la mujer no debía comprometer su integridad moral y espiritual. Una 
violación a tales limitaciones iba en detrimento de la verdadera libertad que idealizaba para la mujer, de la mujer verdaderamente emancipada. Los temores morales de Avellaneda aportan una perspectiva equilibrada sobre la lucha en contra de la marginalización de la mujer. Tal batalla no debía librarse en base al argumento de la mujer como víctima social, si tal victimización era la consecuencia directa de su ligereza moral.

Las preocupaciones feministas eran un tema recurrente en los escritos de Avellaneda (Pastor 43). La primera ola del feminismo que se produjo a lo largo del siglo XIX y principios del XX, abogaba por las igualdades civiles, y venía de la antigua querella del siglo XV que prevaleció hasta que Olympe de Gouges (Marie Gouze) escribiera la Declaración de los Derechos de la Mujer (1789). El ideal feminista de Avellaneda se acogía a los temas de aquella primera ola, por ejemplo, el de la Vindicación de los derechos de la mujer (1792) de Mary Wollstonecraft, en donde reclamaba derechos y advertía sobre las consecuencias de la debilidad moral de la mujer. Sucumbir ante la pasión era tan peligroso para el ideario de la mujer nueva como la marginalización social y el exilio del discurso romántico.

Como vimos, un rasgo original de la carta XV a Romero Ortiz consiste en la apropiación del discurso del sujeto romántico. Gómez de Avellaneda comprendía que controlar el discurso era una forma de ejercer el poder: la historia de los discursos, según Foucault, había sido la historia de la sexualidad (en Picon Garfield 17). Su carta violentaba los parámetros éticos y sociales, con un lenguaje desautorizado por las instituciones de poder, y la manipulación del mismo le servía para presentar su versión 
femenina sobre la pasión y el deseo. Con tal acto de apropiación procuraba una autoridad reservada para el discurso masculino.

Luego del entusiasmo que provocara el replanteamiento de la consciencia femenina, hubo una tendencia en ciertas escritoras hacia una visión más centrista a partir de 1850. Algunas mujeres se volvían a contemplar las ventajas de su papel doméstico, a medida de que se convertían en esposas y madres. Escritoras como Ángela Grassi, Cecilia Böhl y Carolina Coronado revisaron sus posturas, y concluyeron que la actividad creativa no debía estar reñida con la función doméstica de la mujer (Kirkpatrick 260, 261). Sus retractaciones coincidían con una llamada al orden, luego que la revolución cultural del romanticismo había desordenado el panorama social y familiar de la década de los treinta. Se intentaba poner las cosas en su lugar. El papel de la mujer en el hogar no la forzaba a abdicar sus derechos civiles, como tampoco a sus aspiraciones en torno a la creación artística.

La inclinación de Avellaneda hacia la poesía religiosa, junto con la exclusión de sus tres tempranas novelas de la edición de su obra completa entre 1869-71, marcan "su distanciamiento de la revisión feminista del romanticismo que había llevado a cabo en sus primeras publicaciones" (Kirkpatrick 264). Su carta a Romero Ortiz, no obstante apasionada, da evidencia de que reflexiona en los parámetros sobre los que debía fundarse la autonomía de la mujer. Parece ser que él tomaba con ligereza toda aquella comunión epistolar, sugiriendo soluciones "humillantes" a su situación. Avellaneda le escribe: "Desde el fatal momento en que el amor dejó de ser esperanza se ha hecho doloroso como el recuerdo" (232). Aquella relación llega a su fin en el mismo año de 1853, con lo que concluye el conjunto de cartas propiamente amorosas que le dirige. 
Tras su corta relación con Romero Ortiz, Gómez de Avellaneda contrae matrimonio con el coronel Domingo Verdugo en 1855. La ceremonia tuvo lugar en el Palacio Real, en donde los reyes actuaron como padrinos. Alcanzaba por fin la estabilidad sentimental y profesional que tanto anhelaba. Luego del éxito de su drama Baltasar, en 1859 regresa a Cuba para recibir repetidos honores. Allí dirige el Álbum Cubano de lo Bueno y lo Bello, revista que tuvo grandes repercusiones dentro de aquella literatura. Su segundo esposo muere en Cuba en 1863, y Avellaneda decide regresar a España, para morir el 3 de febrero de 1873, a la edad de cincuenta y ocho años.

Como profesional de las letras, el legado literario de Avellaneda contribuyó a que al final del siglo XIX una escritora no fuera algo desconocido. Ella, entre otras precursoras de las letras hispanas, "habían sembrado ya el desconcierto en el panorama cultural de la nación y habían allanado el camino a las futuras mujeres escritoras [...]”. Pero demostraron además, que la "pasión, el desasosiego, la valentía y la libertad no restan feminidad a la mujer" (Caballé 36). Además de su extensa obra literaria, Gómez de Avellaneda dejaba un legado íntimo como testimonio de su ingenio y espontaneidad artística. Las cartas aquí comentadas ilustran tres momentos de su intensa vida. En ellos consolidaba su identidad enfrentada a la sociedad decimonónica, vocera de una visión particular sobre el amor y el deseo.

Raras veces se ha conservado un conjunto de testimonios y confidencias en español de un escritor, como Gómez de Avellaneda, quien fuera en su tiempo vocero del arte de dos orillas culturales. Sus epistolarios nos ponen en contacto con una sensibilidad que es a la vez arte y realidad. No obstante, estos textos, como testimonio de su vida, se 
muestran "extrañamente modernos en nuestro presente". ${ }^{48}$ Escribir cartas le proporcionó la satisfacción de convertir sus vivencias en un proyecto estético: "yo no rehúyo nunca el comunicarme con las gentes de talento que me dispensan el obsequio de procurarme este goce" (173). Una idea similar aparece en la novela ya citada: "estas cartas, [...] son la vida para un amante ausente $[\ldots]$. Mientras se leen se cree, se ama, se espera, se goza; mientras se leen, ellas llenan el vacío del mundo y del corazón" (63). Además, su escritura epistolar no difiere significativamente de su narrativa. Con esto demostraba que, por lo general, la escritora del siglo XIX no solía abandonar su oficio al escribir cartas.

Gómez de Avellaneda inició su escritura íntima con su recuento autobiográfico. Esa fue su fórmula de crear el mito fundacional de la entidad que de la escritora ha prevalecido hasta este día, una "postulación estética, hecha con palabras, con un discurso [...], que rebasa cualquier verdad histórica o cualquiera intención autobiográfica" (Arrufat xxx). Su lenguaje autobiográfico y epistolar revela la profundidad con la que aborda cada tema, además de su preocupación estilística. Las cartas así como la autobiografía adquieren una "dimensión ficcional y literaria" (Selimov 34). De sus cartas, "lo que mejor nos ha llegado documentado es su amor por Ignacio de Cepeda, recogido en el epistolario amoroso que ella le dirigió y que él, de talante frío y temeroso, guardó [...]” (Caballé 368). Ellas muestran además su visión particular del mundo, donde la marginalización de la mujer se convertía en una fuerza creativa de "rebeldía estética" (Picon Garfield 10). Temas como el amor, el reproche, la duda o los celos, se tratan con un sistema de estrategias persuasivas que con frecuencia apela a la lógica del

\footnotetext{
${ }^{48}$ Ver "Mi amor, mi juez", Mercedes Arriage Flórez. Anthropos, 2001, pp. 36.
} 
lenguaje. Su discurso amoroso se valida y autoriza a sí mismo. Tanto Cepeda como Romero Ortiz debieron de haber coincidido en que Gómez de Avellaneda nunca perdía de vista a su lector, por lo que estaba siempre consciente de los posibles efectos del lenguaje.

El estudio de las cartas de Gertrudis Gómez de Avellaneda puede abordarse desde diferentes perspectivas. Con interés histórico y biográfico, sus cartas aportan información de primera mano de la gran actividad artística que ocupaba al público peninsular de su entorno. Sus misivas tienen además un color de crónica social y de costumbrismo, así como también del impacto del romanticismo como movimiento cultural. Contienen reflexiones sobre la filosofía de la vida y su cosmovisión sobre los problemas que aquejaban a la sociedad de su época. Aún más, Avellaneda revela un profundo entendimiento de la psicología humana. Ya por influir en la voluntad de su interlocutor, o por expresar su preocupación por el destino social de la mujer, Avellaneda escribió cartas que compiten con el resto de su obra literaria en profundidad de pensamiento, estrategias persuasivas, estilo y sensibilidad. Su habilidad para transferir su drama personal al contexto de los temas universales, terminó por cautivar la admiración del lector de todos los tiempos. Dejaba abierta la posibilidad de un replanteamiento del papel de la mujer en la sociedad burguesa, y una apertura hacia el reconocimiento de su derecho a un espacio expresivo. 


\section{CAPÍTULO III}

\section{El epistolario de Juana Borrero: el poder de la intimidación.}

\section{Borrero, figura de transición entre dos estilos literarios.}

La obra epistolar de Juana Borrero es un conjunto de cartas de amor que, en más de ochocientas páginas, documenta los acontecimientos del último año de su vida. Con su dedicación hora a hora a esa empresa, reclama su necesidad del espacio privado, de la expresión íntima y de la libertad de la forma, características comunes no sólo a la carta, sino también al diario. Trascendían allí las vivencias de una familia de intelectuales habaneros durante el año en que se inicia la Guerra de Independencia, así como también las circunstancias que la llevaron al exilio. Dentro de la promoción de los poetas de aquel período, la lírica de Borrero era la más original y la mejor dotada, pero su negativa a escribir para publicar hizo que su obra fuera exigua (Vitier, Lo cubano, 236). ${ }^{49} \mathrm{Su}$ epistolario, por el contrario, es extenso, aunque sólo logra alcanzar el carácter anecdótico que la identifica como una adolescente atormentada. No obstante, como poeta que escribe a otro poeta, en sus cartas aparecen versos, prosa poética, microrrelatos, textos que unas veces surgen pulidos y acabados, y otras espontáneos y fragmentados. Tal vez sin proponérselo, con su escritura epistolar dejaba constancia de lo que fue el paso y la permanencia del romanticismo dentro del modernismo en la literatura cubana.

Juana Borrero Pierra nace el 18 de mayo de 1877 en La Habana, Cuba, un año antes de que se firmara el Pacto del Zanjón. Había nacido en seno de una familia de artistas y poetas. Su padre, Esteban Borrero, fue médico, educador, además de haber sido

\footnotetext{
49 Juana renunció a escribir para publicar luego que conociera a Carlos Pío, así como lo expresa con frecuencia en las cartas (EII 44).
} 
veterano de la Guerra de los Diez Años. Juana demostró un talento especial para la pintura desde los 5 años. A los 7 años escribe sus primeros versos, y a los 14 publica su poema "Vespertino" en La Habana Elegante. Fue colaboradora de las revistas literarias El Fígaro, Gris y Azul, y Las Tres Américas. En 1892, durante un viaje con su padre a Nueva York, conoce a José Martí, quien le dedica una velada literaria.

La casa familiar de los Borrero en Puentes Grandes era un "centro del modernismo naciente en Cuba” (Vitier, Lo cubano 214). Así Juana conoce a Julián del Casal, poeta modernista con el que entabla una extraña relación afectiva, pero la muerte repentina del poeta en 1893 le produce una grave depresión emocional. En 1894, con la lectura de Gemelas, Juana queda deslumbrada con el arte modernista de los hermanos Uhrbach, Federico y Carlos Pío. Con este último se compromete secretamente, relación que se convierte en el pretexto de escritura del Epistolario. En 1896 marcha con su familia al exilio en Cayo Hueso, para morir a los 18 años, el 9 de marzo de 1896, un día antes de cumplirse un año de haber conocido a Carlos Pío Uhrbach.

De acuerdo con Cintio Vitier, transcriptor de las cartas, el estilo de Borrero es el de los "Ultra-románticos" o poetas del fin de siglo, los modernistas ("Las cartas" 22). Hoy, la distancia histórica ha propiciado un proceso revisionista desde múltiples perspectivas, lo que obliga a replantear los parámetros de análisis en torno al arte finisecular. Iván Schulman explica:

Si revisionamos el modernismo para incluir no sólo los textos más leídos - principalmente los de la poesía - sino las crónicas, los ensayos, las cartas, los cuadernos de trabajo, y la 
novelística, ampliamos la óptica de esta literatura

emancipadora; entenderemos mejor que se trata de un proceso

de leer el mundo moderno desde la perspectiva individual del

sujeto, un proceso iniciado en la segunda mitad del siglo XIX

que continúa hasta nuestro días con calas de ajustes y

transformaciones culturales y literarias (El proyecto 23).

Tal perspectiva individual y emancipadora en Borrero es la del sujeto que intenta trascender su propia humanidad en medio de la tragedia familiar y nacional. Sus inquietudes le inspiran la idea de un mundo epistolar construido sobre dos grandes temas, Amor y Arte, temas en co-dependencia y realización simultánea, con los que intenta suplantar la realidad.

En el prólogo al Epistolario, Vitier llama la atención a la "gran riqueza de registros" de estas cartas, pero advierte que tales riquezas se encuentran más allá del lector apresurado que va en busca de una lectura antológica (11). Sin embargo, una relectura de estas páginas revela la necesidad de un análisis selectivo que identifique, señale e independice la labor artística de la simple comunicación escrita. Bajo ese plan de análisis, se descubren textos en donde prevalecen el diseño, la unidad temática, la organización y la estructura, elementos que añaden al propósito comunicativo una función artística que es insoslayable.

De acuerdo a lo anterior, en el presente análisis intento demostrar que existe un discurso intimidatorio en el Epistolario de Juana Borrero, organizado en torno a cuatro de los rasgos distintivos que caracterizaron al arte modernista. Primero, el uso recursos multi-sensoriales y de imágenes muy plásticas, efectos para los que la escritora se apropia 
de técnicas de diferentes disciplinas del arte. Me concentro en el trato del paisaje como renovación parnasiana de un tema visitado por los románticos, así como también en la conexión sujeto/universo que los simbolistas logran a partir de la interiorización del paisaje. Segundo, la recreación de ambientes místicos y la apropiación del ornamento litúrgico/religioso, con los que Borrero crea un impacto dramático e intimidatorio. El gusto que desarrolló el artista modernista por la imaginería de una religiosidad decadente señalaba la necesidad de ornamentar su vacío existencial, huir del horror vacui y reaccionar contra los valores burgueses de la sociedad del fin de siglo. Tercero, está la tendencia en Borrero a crear a partir de la experiencia alucinante y de la influencia de los sueños. Ya como escapismo o como expresión de hastío ante el mundo, el artista finisecular experimentó con medios artificiales para violentar sus sentidos, materialización de paraísos artificiales que se procuraba en nombre del Arte. Por último, la presencia de lo fantástico y de fenómenos inexplicables en la creación artística. Con la tendencia al relato fantástico heredada del romanticismo, el artista intentaba contrarrestar el prestigio de la ciencia, a la vez que con un lenguaje renovado rechazaba la estética del realismo y del naturalismo. A través de esta selección observamos además la evolución que en concepto y estilo la obra epistolar de Borrero marca una pauta innovadora en la escritura de la mujer del fin de siglo.

\section{Realidades virtuales en el arte de la persuasión: la escritura como paisaje. Cartas 9} y 99.

El paisaje y los fenómenos naturales habían sido para los románticos reflejo de sentimientos, estados de ánimo. Pero para el artista modernista la Naturaleza es contexto de una realidad superior, lugar de encuentro de conexiones invisibles que lo unen al plan 
universal. En contraste con el romanticismo, el artista modernista apela a la "óptica convexa", es decir, a la habilidad del poeta de captar para sus textos imágenes interiores a partir de la mirada exterior (Schulman 149). Este principio, en concepto y forma, aparece con frecuencia en las cartas de Borrero, especialmente en aquéllas que escribió al principio de su relación con Carlos Pío. Hemos seleccionado dos cartas pertenecientes a este ciclo inicial, con las que la escritora intenta deslumbrar a su interlocutor con su virtuosismo epistolar. En este análisis identificamos y analizamos la propuesta de Borrero hacia la renovación de la temática romántica en la contemplación del paisaje.

A fin de organizar y poner en contexto las cartas del Epistolario, Cintio Vitier antepone algunas páginas del diario de la escritora. En su primera entrada, de "1894 - 7 y media noche" Juana escribe: "Acaba de llegar a mis manos el libro de los Uhrbach, Gemelas”. El poemario se lo había traído su padre, y sus autores eran los poetas matanceros, Federico y Carlos Pío Uhrbach. Ambos colaboraban en las más prestigiosas revistas de arte modernista de la época y, según Vitier, estos jóvenes escritores junto con Juana eran las "promesas mayores de la nueva generación” de los poetas en Cuba (Lo cubano 214).

Para febrero de 1895 (el mes de La Guerra Necesaria o Guerra de Independencia), Juana escribe en el diario: “Antes de dos meses tú serás mío o yo estaré muerta” (I 41). ${ }^{\mathbf{5 0}}$ Se refería a Carlos Pío, el mayor de los dos hermanos, a quien aún no conocía. A esta entrada del diario siguen 6 cartas dirigidas a ambos, tras las que Vitier incorpora las páginas del diario que corresponden a las fechas del 2 al 7 de abril de 1895. Una de ellas

\footnotetext{
${ }^{50}$ Todas las citas del Epistolario que aparecen en este ensayo mantienen la ortografía que se usó al transcribirlas, y el énfasis de las citas corresponde en su totalidad al énfasis del autor.
} 
lee así: “Será verdad...que soy amada?”. Aquí comienza lo que constituye el epistolario amoroso de Juana Borrero, es decir, el documento marcado como el documento o la Carta 9 que ahora nos ocupa. Borrero la encabezaba con la frase “iSiempre tú!”, y con un fragmento de su soneto "Himno a la vida". Sus elementos contextualizadotes son "Madrugada. 4 y media", lo que debió corresponder a la madrugada entre el 7 y el 8 de abril. La estructura del texto se compone de tres momentos descriptivos, a saber, encuentro anímico del sujeto con la Creación; advenimiento del sol como Astro de la Vida; identificación del amado con el Supremo Artista.

La carta comienza de la siguiente manera:

Amanece... las estrellas palidecen, el espacio se aclara poco a poco... allá, tras la oscura arboleda un celaje purpúreo anuncia la llegada de Febo. Las aves despiertan. La brisa húmeda de la mañana penetra en mi alcoba y orea mi frente fatigada por el insomnio. No he dormido.

Amanece... mi alma se siente iluminada por el alba interior de la esperanza...El sol de la Ilusión despunta radioso en el cielo, hasta ahora nublado, de mi existencia, y por eso espero el alba, después de una noche de insomnio... para presenciar la salida del sol inmortal, para regocijarme con el espectáculo de la Naturaleza que con su orgía de luz parece celebrar sus nupcias con el astro de la Vida!

Muy temprano en el Epistolario se desdibujan los límites conceptuales y estilísticos entre la epístola y la creación artística. En la evolución de los textos, la carta personal se había 
desarrollado como un género menor a partir de la retórica, la cual es la "capacidad de servirse de la lengua -con su poder de sugestión y de emoción- para convencer a un auditorio" (Marchese y Forradellas 349). Nos damos cuenta en el pasaje anterior que Borrero intenta deslumbrar a su interlocutor con su lenguaje poético, y es por eso que escribe con el cuidado de la forma que caracteriza la prosa poética.

La carta en cuestión está escrita en su totalidad en prosa poética, segundo tipo entre las obras líricas en donde los sentimientos y las impresiones del sujeto son más importantes que lo narrado. Esa modalidad había entrado en el modernismo como reacción a las vertientes románticas del realismo y el naturalismo, y además como rechazo al utilitarismo de la prosa en la crítica social y política. La prosa poética había surgido en Francia con los poetas "malditos" y simbolistas como Mallarmé, quien tradujo en prosa poemas que Edgar Allan Poe escribiera en verso (Jiménez y Morales 344).

Note que la actitud de panteísmo poético del pasaje se manifiesta como el deseo del artista de aprehender la espiritualidad del mundo natural. En la corriente simbolista que se dio dentro del modernismo se representaba al mundo como un entorno de misterio, y se pensaba que la misión del artista era descubrir las correspondencias ocultas entre los objetos. En el pasaje anterior, lo contemplado cede su relevancia estética a su capacidad sugerente, por lo que el artista descubre conexiones invisibles entre la alborada y un despertar interior. La belleza ya no emana de lo contemplado, sino de la clarividencia del sujeto lírico quien se incorpora al espectáculo como eje de una visión doble. En tal estado de admiración contemplativa, los signos apuntan hacia nuevos referentes, por lo que el paisaje evoca una realidad superior. 
Con estrategias visuales y sensoriales, Borrero obliga al lector a observar con la mirada del artista, que en ella es la del paisajista y también la del poeta. Bajo esta perspectiva estética ocurre el segundo momento narrativo que así:

El sol flamígero asciende, asciende...La enramada entona su epitalamio, el río se desliza bullicioso sobre su lecho de musgosas piedras y al correr deja desbordarse sobre la fresca grama de la orilla el blanco manto de su espuma. Las aves despiertan... Sus gárrulos arpegios vibran en el aire luminoso como el himno de amor más dulce de la creación entera...

Martí escribió en "El carácter de la Revista Venezolana" de 1881 (lo que se considera como el primer manifiesto del movimiento modernista) que "el escritor ha de pintar, como el pintor" (en Jiménez y Morales 59). Este concepto se cumple en Borrero en un sentido literal y no metafórico. Juana entendía la composición, técnica y función de los recursos visuales. Además de su intuición estética, había sido alumna de la Academia de Dibujo y Pintura de San Alejandro entre 1887-1888, luego que Miguel Meleros, su director, permitiera el ingreso de las mujeres en 1879. Más tarde continuó sus estudios de pintura con la disciplina del artista. ${ }^{51}$ Era habitual que ilustrara lo que escribía con dibujos inspirados en el Art Nouveau, estilo que ve en la línea curva que predomina en la naturaleza un asomo de sensualidad. El resultado es que sus cartas son una síntesis entre

\footnotetext{
${ }^{51}$ Algunos de los trabajos de Juana estuvieron expuestos en espacios promocionales. Su cuadro, "Pilluelos", es hoy parte de la exhibición de la sala de arte colonial del Museo Nacional de Bellas Artes de La Habana.
} 
texto y lienzo, como ella misma lo explica: "Yo quisiera poder escribirte con letras de luz y luz" (I 366).

Más que describir lo que contempla, en el pasaje anterior Borrero intenta captar un momento (el amanecer), una impresión. La escritora conocía los principios del arte impresionista, porque se puso en contacto con esa corriente artística durante sus viajes a los Estados Unidos en 1892 y 1893 . El impresionismo para entonces había impactado tanto la pintura como la literatura, y se había constituido en una de las dos vertientes del simbolismo. ${ }^{52}$ Sus técnicas consistían en representar sensaciones y suprimir el intelectualismo, anular la realidad para entrar en el mundo de las impresiones. Juana explica este concepto en una de sus cartas, de la siguiente manera: "La sensación me embarga por completo y no deja lugar al proceso ideológico" (EI 66). El sujeto lírico del pasaje penetra la belleza del mundo de los objetos y establece una relación anímica (no lógica ni conceptual) con ellos. Con la frase, "el alba interior”, sintetiza su experiencia totalizadora de comunión con la creación.

El romanticismo había heredado de la estética del siglo XVIII la sensibilidad ante lo bello. El artista encontraba un placer desinteresado en la contemplación del objeto, concepto que luego evoluciona para que los elementos naturales y sus fenómenos fueran reflejo del sentimiento. Pero en este pasaje Borrero deja a un lado la sensibilidad contemplativa y se apropiaba del objeto para sintetizarlo (estrategia del símbolo) en las impresiones que se activan al contacto con él. Para lograr tal efecto describe el objeto a

\footnotetext{
${ }^{52}$ Generalizado en Europa y en Hispanoamérica en las tres últimas décadas del XIX, se define como "el retrato marcadamente subjetivo del paisaje o entorno exterior, de manera que la creatividad del poeta selecciona sólo aquellos elementos que más convienen a su emoción y los describe no como son en realidad, sino según las sensaciones que en su conciencia subjetiva producen tales referentes externo. (Jiménez y Morales 37).
} 
partir de su efecto simultáneo o sinestesia, que es la técnica de reproducir dos o más sensaciones diversas en un solo núcleo textual imaginativo, como en "el aire luminoso como un himno". Además, la escritora yuxtapone impresiones cromáticas por medio de una adjetivación que sugiere, pero no limita, una gama de colores: la "musgosa piedra" y la "fresca grama".

Adviértase que la artista trabaja con los sonidos y sus resonancias acústicas, característica propia del arte finisecular, como en la frase "arpegios vibran en el aire". Tales efectos son posibles gracias a la personificación de los elementos naturales, como al describir la enramada que entona y el río que se desliza. Además, se rescata la elegancia de la palabra rara en el uso de los términos "flamígero", "gárrulos", "radioso" y "epitalamio", tendencia hacia el cultismo con que el arte reacciona frente al lenguaje del realismo y el naturalismo. Todas estas estrategias se incorporan a un armonioso sistema de proyecciones múltiples, lo que resulta en una única y sugerente experiencia sensorial.

El tercer momento descriptivo surge al Borrero incorporar una salvedad metaliteraria que vincula la labor artística a la tarea epistolar. Para ello reflexiona sobre el acto de escritura como tributo al interlocutor:

La luz del sol penetra libremente en mi aposento filtrando mis vidrieras... yo entre tanto te escribo, te escribo para decirte una vez más lo que te he dicho tantas veces...! [...] Que creo en ti como en Dios, que espero en ti, que te doy mi alma toda sin restricciones, sin vacilaciones y que soy tuya, tuya como el sol es de las flores, como las flores son de la Naturaleza como la Naturaleza es del Supremo Artista... 
Adviértase que la fusión del paisaje con el acto de escritura lo glorifica, y nótese además que Dios y el Amado coinciden en la creación de la alborada exterior y de la íntima. La artista descubre que el amor la reconcilia con el mundo natural, y encuentra en el poder purificador del arte las correspondencias invisibles que la insertan al plan universal. El párrafo/estrofa adquiere la solemnidad del rezo ("que creo en ti como en Dios"), homenaje que rinde en reconocimiento al poder redentor de un arte que se inspira en el principio de lo bello.

La elipsis marca el fin de la prosa poética y la reincorporación al formato de la carta, pero el lector ya percibe esa transición cuando la función del tú poético desaparece y se activa la del tú epistolar (“¡Oh amor mío! ¿Qué hermosa está la mañana”). El propósito de ese paréntesis poético había sido deslumbrar al lector con el poder de su discurso poético, intención que ratifica al final de la carta: "Eres mío, mío aunque no quisieras serlo, te he esclavizado con mi ternura... me perteneces por derecho de conquista". Agregaba a ello una despedida que aquí funciona como elemento contextualizador del pasaje: "te quiero te amo te adoro te idolatro! ¡Quiéreme, ámame, adórame, idolátrame". Vitier opina en el prólogo a las cartas que esta caprichosa puntuación se debe a que la escritora no atina a corregirse en los apuros de la pasión (9). Sin embargo, la recurrencia de estas formas en el Epistolario marca un patrón estilístico, una libertad gramatical con la que Borrero crea su sello distintivo de originalidad rítmica. El ritmo galopante provocado por la ausencia de las comas destaca la intención imperativa de la frase que le sigue: "quiéreme, ámame".

La carta 9 que inaugura el Epistolario demuestra que el arte en Borrero es la consecuencia natural de la experiencia humana. Para ello se vale de técnicas parnasianas 
y simbolistas que renuevan la propuesta romántica de la función del paisaje en el texto. Es así que la carta como texto se coloca dentro de la retórica romántica que se "coló en el modernismo" (González 18). Como deudora de ambos estilos, Borrero aparece como figura de transición entre ambas tendencias.

Además de la experiencia de lo bello como representación del sentimiento, durante el primer Romanticismo el artista expresó con lo sublime su inferioridad humana ante realidades insondables que no era capaz de comprender ni describir (Eco, Historia 267). Un número de cartas de Borrero ilustra este concepto, por ejemplo, cuando intenta describir el espectáculo nocturno: "Salgo a la terraza y veo el firmamento como yo lo sueño; a trechos nublados a trechos cubierto de estrellas... Entro porque me atormenta una sed insaciable de besar a Aldebarán que esplende en la altura su fanal purísimo" ( $E I$ 66). El deseo frustrado de besar a la estrella y la inquietud del sujeto ("Salgo", "veo", "entro") hablan de un drama personal que busca respuestas en el espectáculo sideral. ${ }^{53}$ Sin embargo, cuando la experiencia ante bello y el sentimiento de lo sublime fueron insuficientes, Borrero se da a la creación de realidades artificiales, mundos alternos en donde refugiarse de su angustia existencial.

Para septiembre de 1895, seis meses antes de su muerte, la salud de Juana había comenzado a deteriorarse, por lo que los padres deciden enviarla al cuidado de una familia en la quinta Larrazábal. La separación de Carlos Pío y de las tertulias de la casa de Puentes Grandes la abruma, y se da cuenta de que la ausencia sería sólo superable por medio de la imaginación. Juana se explica: "sentirte a mi lado no relativamente sino con mi alma, dentro de mi alma!" (EII 139). Tal anhelo de fusión anímica con el otro era un

\footnotetext{
${ }^{53}$ Ver poema no publicado "En la terraza" (EI 113), con un tema similar.
} 
empeño, según Vitier en el prólogo a las caras, "para el cual se ponen en juego todos los recursos de la astucia pasional [...]" (11). Este es el tema de la Carta 99, la configuración de un mundo virtual con el que intenta destruir, ya no acortar, la distancia que la separa de su interlocutor. Con fecha del lunes 6 de septiembre, la carta se titula "Misiva Lilial. Hora gris", y está encabezada por con un fragmento del poema "Yvone" del poeta Abraham Z. López Penha (1894-1925). La había comenzado escribiendo una crítica literaria sobre el libro Cromos del mismo autor, libro que describe como "un joyero donde abundan los rubíes". ${ }^{54}$

La sección a analizar se independiza de la misiva general a la señal "Y basta de modernismo y hablemos de nosotros", y la frase, "la vereda que conduce a la verja de entrada", señala el umbral imaginario que separa la realidad y la fantasía. El pasaje se organiza en tres momentos estructurales, que son, la caída de la tarde, la apoteosis nocturna y la interacción entre el sujeto lírico y el amado. La carta comienza así:

La tarde está espléndidamente inspiradora. Después de la lluvia se ha despejado el éter y el sol se hunde velado por una ligera bruma rósea. Frente a mi ventana y festoneando la vereda que conduce a la verja de entrada, los lirios se abren a la luz de la primera estrella. La naturaleza se duerme...el alma despierta. Los delirios aletean sobre las corolas. Es la hora de los sueños, de los dulces sueños de amor...La fantasía, mariposa vesperal, abre las alas inquietas y vuela a perderse en la bruma azulada de

\footnotetext{
${ }^{54}$ Son numerosos los temas sobre crítica literaria y de arte en general en el Epistolario, por lo que Vitier remite añade el apéndice "Escritores modernistas que aparecen citados en las cartas de Juana Borrero", así como una "Nota Final", sobre las revistas literarias que aparecen citadas (pp. 385- 41).
} 
las lejanías. El firmamento como un ópalo inmenso se va cubriendo de estrellas y la luna, soberbia y casta, alza la frente altiva tras el perfil oscuro de la arboleda. ¡Oh ensueño-flor! jábrete como un lirio a la caricia fría de Selene!. En esta hora de íntimas nostalgias de laxitudes enervantes y de bullidoras quimeras se abren en el alma todas las corolas de los anhelos! Cuando la rima aletea en la mente y en los labios palpita el beso-estrofa... Entonces. La tarde muere.

En este pasaje parece que resurge en concepto el vuelo intelectual del Primero sueño de Sor Juana: "La naturaleza se duerme...el alma despierta". No obstante, Borrero no se inspira en la lógica sistemática del poema barroco sino en una sabiduría estética que intuye en la tarde. Nótese que el punto de observación inicial es a través de una ventana, perspectiva desde la que el sujeto contempla un paisaje que se enmarca como un cuadro.

Rompiendo con la tradición lírica que asociaba a la mujer con la flor como objeto de placer (Kirkpatrick 197), la escritora se identifica con ésta como creador de fantasías estéticas: los delirios aletean en sus corolas, así como el amor en la inspiración del artista. Se confirma esa idea con la relación fonética y conceptual entre las palabras "sueño" y "ensueño" y entre "lirio" y "delirio", juego de ideas más que de palabras, que se desarrolla a medida que el relato avanza. Los lirios no son testigos pasivos de una visión onírica. ${ }^{55}$ Su presencia parece hacer guiños, no al lector, sino al artista, porque le invitan a participar de una experiencia sensorial que la conduce a la creación artística: "íntimas

\footnotetext{
${ }^{55} \mathrm{El}$ artista modernista se sentía atraído hacia las representaciones florales, según Umberto Eco, por la "seudoartificialidad de una orfebrería natural [...] fragilidad y corrupción que invade el mundo vegetal, el rápido paso que en él se produce entre la vida y la muerte" (Eco, Historia 342). En Lucía Jerez (1885) de Martí, la magnolia adquiere importancia simbólica, como testigo mudo del drama de la novela.
} 
nostalgias de laxitudes enervantes", cuando la "rima aletea en la mente". Este es el espacio propicio a la inspiración, la rima estará por llegar como consecuencia natural de la experiencia humana. Amor y rima son componentes de su binomio artístico: el "besoestrofa”.

A la llegada de la noche, el sujeto descubre nuevas sensaciones con la ausencia de la luz. La carta continúa:

La sombra envuelve en su caricia de luto el cofín remoto del paisaje. Una sutil niebla blanca y transparente como un crespón etéreo, tamiza el disco de la luna, y arropa entre sus pliegues la frente moribunda de Sirio. La enramada se agita murmurando en voz baja conjuros extraños... De pie junto a la blanca baranda, bajo las arcadas, contemplo el paisaje soñoliento y aspiro el alma de los nardos que se abren. Pienso en ti. Pienso que nos perdemos por el curvo sendero que tapiza con su filigrana sombría la sombra temblorosa del follaje de los algarrobos. En la penumbra juegan los silfos del ensueño. Los lirios abiertos como estrellas de mármol rosa se duermen también y sueñan. Sueñan con las mariposas, con las inquietas mariposas matinales.

Obsérvese que en este pasaje la sombra gradualmente suplanta las funciones de la claridad al precisar contornos. Su efecto, que depende de la ausencia de luz, sucede en dirección contraria a la fuente de aquélla, y sirve para determinar el conjunto espacial en la distancia. Es la sombra y no la luz la que descubre las cualidades ocultas de los 
objetos: "la caricia de luto del confín remoto", "la sombra tenebrosa del follaje". Los efectos de la luz y de la sombra fueron rasgos de especial importancia para el movimiento impresionista, es por eso que el artista abandonaba el estudio y salía al encuentro de la naturaleza, como aquí lo hace el sujeto lírico.

Nótese que la composición del pasaje se logra por medio de la adjetivación, que aquí funciona para crear un espacio idílico con un giro de misterio: "paisaje soñoliento", "confín remoto", "conjuros extraños". La adjetivación (antes y después del sujeto) sirve además en la composición del ritmo, como en "sutil niebla blanca y transparente", frase marcada por un ritmo ondulante. Se utiliza también la similitud fonética de los derivados, como en "filigrana sombría de la sombra", además de que nuevamente se apela a la personificación de los objetos, como en "la sombra envuelve" y en "juegan los silfos". Otro recurso poético aparece en la sustitución de las palabras en la frase, "aspiro el alma (no el perfume, ni el aroma) de los nardos". Por último, de acuerdo con el ideal modernista de insertarse en la temática universal, la escritora se vale de motivos mitológicos, como en "Selene" y en "Sirio", estrella que la mitología asocia al perro de presa en la constelación de Orión.

A continuación, Borrero inicia el tercer momento narrativo, en donde el interlocutor se incorpora a aquella realidad virtual:

Tú y yo recorremos lentamente el sendero. Tu mano en mi mano mi cabeza en tu hombro, tu recuerdo en mi alma! Tú me hablas muy bajo. Apenas te oigo... Ya tu voz no es más que un suspiro, un hálito, una ráfaga tibia y acariciadora... Te has callado. Levanto los ojos y te miro. Hay tal dulzura en tu 
mirada, tal súplica en tus pupilas turbadoras que me siento poseída del vértigo delicioso de los dulces transportes...

«Puedes besarme. ¿No soy tuya?»y el beso rítmico vibra como

un himno de indefinible dulzura. Y los lirios entre sueños, se

sonríen, y las frondas se agitan en silencio, y yo sobre tu

hombro desfallezco, desfallezco... ¡Oh dulce hora, hora

misteriosa de amor y de ensueños! ¡Oh flor-ensueño ¡oh noche!

El aura refresca.

Nótese que Borrero hace que el interlocutor se incorpore con un papel activo, para que sean sus acciones, y no las de ella, las que impartan verosimilitud al pasaje. Es él quien avala aquella realidad por medio de aportar sensaciones concretas, por ejemplo, con la intensidad de la voz, la calidez del aliento y el efecto de la mirada. Borrero además da relieve a su texto al trabajar con la disposición de los planos espaciales. Así, cuando él calla, ella le dirige una mirada desde un plano inferior: "levanto los ojos". Nótese también que al escribir, "Puedes besarme", la escritora establece un diálogo que no debe confundirse con el diálogo epistolar. Este es un diálogo ficticio o percontatio entre el escritor y su interlocutor textual, que tiene como objeto describir o representar una situación a la que se intenta impartir credibilidad. Los breves parlamentos surgen en un universo a otro nivel del mundo epistolar, con los que transporta al interlocutor a un contexto idílico.

Como autor implícito, Borrero tiene la consciencia estética del principio de la simetría y de la composición circular. Obsérvese a continuación el pasaje que da fin al texto: 
Es hora de regresar. Apóyate en mi hombro, volvamos volvamos. Dejemos atrás la vereda sombría, los misterios nupciales de la enramada, las corolas nevadas de los lirios dormidos. Vamos junto a la blanca baranda. Allí junto a las columnas bajo las amplias arcadas. Desde allí se descubre el plafond del firmamento poblado de estrellas. Nos sentaremos ¿quieres? sobre la escalinata de mármol. Me reclinaré sobre tu pecho y me contarás esa historia íntima y siempre nueva de la ternura soñadora. Me dirás que me amas. Me dirás que me adoras. Me dirás que eres mío y un arranque espontáneo me echarás los brazos al cuello! [...] Siéntate. Háblame... Dime esa frase que tanto me conmueve y que me envuelve como una ráfaga de brisa fragante... Bésame. Bésame lenta dulcemente, Dame el beso soñado, el beso puro y tranquilo, apasionado y suave. El beso casto, el beso sin fiebre, el beso interminable como aquél que desposó nuestras almas. ¡Oh, dame el beso soñado!

La referencia al beso casto del trovador medieval, Jaufré Rudel, a su amada es evidencia en Borrero de su sustrato romántico. Borrero asigna un valor emblemático al beso y a la acción de besar, y forma parte de lo que podríamos llamar dentro del contexto del Epistolario la mitología de la imaginación. ${ }^{56}$ El beso es síntesis y símbolo supremo que identifica y sella su relación amorosa, así como lo encontramos en "el beso casto" (Carta 10); "el beso luz” (Carta 112); "el beso estrofa", "el beso soñado" (Carta 99); "el que he

\footnotetext{
${ }^{56}$ Otro de los mitos del Epistolario es el de la noche del encuentro con Carlos Pío o la noche del eclipse, así como la lectura del poemario Gemelas, en donde creyó encontrar un vínculo premonitorio que la uniría para siempre al poeta matancero.
} 
creado" (Carta 148), además de ser el tema del poema que dictara desde su lecho de muerte, la "Última rima".

Obsérvese además en este pasaje la intención imperativa en las expresiones "háblame”, "dime”, "bésame", intención que resulta aún más sugerente cuando se expresa en sus formas futuras "me contarás" y "me dirás". Aquí no se trata de contar la historia, sino de controlar las acciones de la segunda persona con la predestinación narrativa que luego se daría en las vanguardias. ${ }^{57}$ Para dar cierre al pasaje, la escritora añade una salvedad metatextual con la que justifica su motivo escritura:

Despierto! Estoy de pie junto a la blanca baranda, cerca de las erguidas columnas, bajo las arcadas. [...] ¡Ay! todo ha sido un sueño, un delicioso nocturno hijo de mis ansias secretas...Y mientras yo te busco para recoger en tus labios la nota interrumpida del beso soñado, la luna, soberbia y casta, ilumina el curvo sendero y las corolas nevadas de los lirios dormidos...

- Juana Borrero -. 1895.

El pasaje concluye de manera circular cuando el sujeto regresa al lugar de partida, "la blanca baranda". Desde allí Borrero presenta el motivo de la escritura, "todo ha sido un sueño", con lo que hace desvanecer el espacio virtual anterior.

No obstante, el que la escritora haga pervivir ciertos elementos de su visión nocturna sugiere cierto grado de continuidad narrativa. Su técnica ha consistido en desplazar al sujeto entre planos que yuxtaponen arte sobre arte, por lo que la alegada

\footnotetext{
${ }^{57}$ Un efecto similar de las formas en tiempo futuro para la segunda persona aparecen en Aura (1962), de Carlos Fuentes.
} 
realidad a la que pretende regresar es un espacio igualmente idílico. Dejaba en el interlocutor la huella de una fantasía ajena, que sin embargo, establecía una compleja relación entre sentimiento y memoria, estímulo y recuerdo. Su firma, "Juana Borrero 1895" es un reclamo de autoría muy frecuente en sus cartas, así como lo es el pseudónimo "Yvone", apropiación del título de un poema de López Penha. Con la escritura de este pasaje, Borrero demuestra la incidencia del legado romántico en el discurso modernista. Aunque se opina que el modernismo fue nuestro romanticismo (Jiménez y Morales 8), el romanticismo de Borrero se supera a sí mismo, en la reformulación del trato del paisaje como pretexto de composición. ${ }^{58}$

En Lo cubano en la poesía, análisis antológico de la poética criolla, encontramos el gradual cambio de actitud del artista ante el paisaje en la evolución de la poesía cubana: “[...] la expresión de lo cubano, ha derivado de la naturaleza al carácter, del carácter a la intimidad del alma" (168). El paisaje aparecía como elemento persuasivo en la visión paradisíaca de Colón, para luego convertirse en el didactismo del inventario forestal neoclásico. Se interioriza al evocar la lejanía y la nostalgia que se dio en José María Heredia (1803-1839) y también en Avellaneda. En Juan Clemente Zenea (18321871), es estado de ánimo y culto de sensaciones, idea asimilada de la poesía francesa y precursora del simbolismo. De acuerdo con Vitier, en Zenea la naturaleza ya no es "en verdad, paisaje, sino hora" (140), como también aparecía en el pasaje analizado. Al llegar a Martí el paisaje es lección moral, capacidad de sacrificio y voluntad de cerrar filas con la causa del humilde: el advenimiento de la plenitud del espíritu.

\footnotetext{
${ }^{58}$ Otras cartas de este ciclo inicial ilustran también la interiorización del paisaje, como por ejemplo, en la Carta 49. En ella Borrero trabaja con las refracciones de una luz que parece descomponerse desde un prisma interior, para dejar su "caricia olímpica" en el papel en que escribe.
} 
En Borrero, figura de transición entre dos tendencias literarias, el paisaje es un espacio de comunión con el universo y símbolo de realidades íntimas. ${ }^{59}$ Pero además de ser "alma" (acogiéndonos a la definición de Vitier) es también "espíritu", sólo que en Borrero, en contraste con Martí, la plenitud se alcanza por la vía de su universo particular, de su mirada panteísta con la que cree ver al Amado en toda manifestación del mundo natural: universalidad del sentimiento.

No obstante, el entusiasmo inicial por el paisaje matinal (que es generalmente el momento más representativo de la paisajística cubana) cambiaría en cartas sucesivas. Juana explica: "Me inspira la naturaleza un odio tan profundo un aborrecimiento tan cabal, que siento por ella una repulsión invencible. [...] Mañana volverá el ardiente Faetonte y empezará otra vez con sus transportes de pasión y sus caricias voluptuosas" (EI 75). La enfermedad parece ser la causa de su retractación de la tradición paisajística, expresada aquí expresa con una metáfora de connotaciones eróticas. ${ }^{60}$ Fuera como fuere, Borrero alcanza a reformular la propuesta romántica en el tema del paisaje: identifica al artista con el sujeto femenino y controla las acciones del interlocutor, transfiriéndole el peso de la verosimilitud. Además, logra la fusión escritura-lienzo que bosquejó Martí para la renovación estética de la escritura finisecular.

\footnotetext{
${ }^{59}$ Ver poemas de Borrero inspirados en el entorno de la naturaleza, como en "Crepuscular" y en "Himno de Vida".

${ }^{60}$ Tal conexión erótica reaparece en su poema "Sol y nieve" publicado en La Habana Elegante, el 12 de mayo de 1895: “¡Sé tú el árbol cubierto por la nieve,/Y yo el rayo de sol!”, tema que con variaciones se adelanta por casi dos décadas al del poema "Otra estirpe" de Delmira Agustini, en Los cálices vacíos (1913). Sobre "Sol y nieve", Juana explica a Carlos Pío: "Y déjame decirte ahora que yo no publico canciones eróticas... Las que han visto la luz últimamente se han publicado contra mi voluntad..." (EI 113).
} 


\section{Religiosidad decadente como materialización de las emociones: sensualidad mística en el epistolario de Borrero. Carta 76.}

En los meses que trascurren durante el verano de 1895, la relación entre Juana y Carlos Pío se consolida. Ella se dedica a escribirle cartas y a componer poemas que permanecieron inéditos hasta la publicación del Epistolario. El hecho que las cartas se intercambian en secreto aporta el grado de intriga y complicidad que hacen de ellas un testimonio de singular atractivo. Manuel Pedro González, en su ensayo Amor y mito en Juana Borrero, escribe: "dudo que exista en lengua española otro epistolario amoroso de tan dramático y profundo contenido psicológico y de tan inusitado valor humano" (77). Tal profundidad de contenido aparece a medida que encuentra pretextos de escritura de más compleja elaboración psicológica, como aquellos en los que se vale de motivos y contextos místicos y espirituales. Decía de sí misma: "Yo creo sencillamente que soy una mística" (EI 201). Según escribe Vitier en el prólogo al Epistolario, estas manifestaciones son "misticismos mal encauzados" (10). Sin embargo, dentro del contexto que aquí nos ocupa, estas filigranas místicas cobran relevancia como instrumentos de escritura en el ejercicio del poder.

Los temas religiosos y espirituales en las cartas de Borrero podrían agruparse atendiendo a su naturaleza e intención. Algunos se distinguen por su función estética, es decir, por la apropiación del elemento religioso como simple imitación gráfica y representativa, en lo que de belleza encuentra Borrero en la emulación del rito. Por ejemplo, ya con humor o con irreverencia artística, la escritora imita oraciones como el Ave María, el Credo de los Apóstoles, así como también los actos de fe y el Decálogo. Por ejemplo, obsérvese este pasaje de la Carta 167: 
$[\ldots]$ amado y redentor mío, por ser tú quien eres, porque te amo sobre todas las cosas, te ofrezco mi vida, pensamientos y ensueños en satisfacción de todos tus pesares, y propongo firmemente ser tuya y confesarte que te adoro; y como confío en tu infinito amor y fidelidad espero que me darás gracia para amarte y perseverar en tu culto hasta el fin de mi vida. Amén.

En otras cartas, las oraciones se integran espontáneamente al texto, como en aquella en la que se desprende del diálogo epistolar y se dirige a la Virgen: "Hazlo perder la memoria. Disipa su pasado, anúlalo en su presente. Hazlo que olvide oh Madre!” (EI 281). Todo esto es parte de una carnavalización epistolar de corte mimético, que parece no pretender ser más de lo ya es: imitación casi paródica.

No obstante, los pasajes de más originalidad, en profundidad de significado y composición estética son aquellos en los que la artista se entrega a la experiencia mística y la presenta como genuinamente suya. Para realizar tales efectos, Borrero se vale del símbolo, recurso heredado del romanticismo que aparece como superación de la metáfora y del símil. Con el símbolo se asocian las ideas por la lógica de la imaginación y no de la razón. Esto sería fundamental en el desarrollo del impresionismo y del expresionismo, ya que para el último logra la materialización de imágenes interiores, independientes del efecto del objeto sobre el artista. Paradójicamente y en busca de una mejor representación de la nueva expresión del simbolismo, el artista modernista volvía su mirada hacia los objetos del mundo burgués cuyos valores rechazaba (Jiménez y Morales 36). En la Carta 76 que ahora nos ocupa, Borrero se vale de imágenes de objetos tomados del mundo litúrgico/religioso, los cuales surgen en el texto dentro de una 
atmósfera de raro misticismo. Con tal ambiente espiritualizado, es posible que la escritora intentara sublimizar el escabroso tema de su carta.

Lo que había motivado la escritura de la Carta 76 era la confesión de Carlos Pío de haber amado a una mujer que para entonces ya había muerto. Juana quedó obsesionada, al punto de materializar aquella revelación en imágenes vívidas y hacerla parte de su conciencia: "Tengo recuerdos lúgubres de lo que no he visto..." (EI 279). Una carta escrita cuatro días antes nos pone en contexto en torno al propósito de la carta en cuestión: "¡Es que siento celos celos terribles de las que te han amado y que comparten conmigo tu pensamiento tu memoria. Sí tu memoria! [...] Quiero anular tu pasado [...] el recuerdo, el recuerdo imborrable...!” (EI 264-265). ${ }^{61}$ Juana conocía el poder de la persistencia de la memoria, del recuerdo. Presentía que la hegemonía sobre los sentimientos de Carlos Pío dependía de controlar su memoria sentimental.

Con fecha del "Martes. 12 y media de la noche. Agosto 7, 1895-", la escritora introduce su tema escribiendo: "tu alma que es mía porque fue para mí creada [...] Esa convicción redentora me salva y te salva...”. El pasaje a analizar comienza cuando el sujeto se sumerge en un diálogo íntimo en el que gradualmente relega las funciones del interlocutor. Éste a su vez parece retirarse como un espectador silencioso. La estructura de la carta se divide en tres partes: las reflexiones del sujeto narrativo, la deconstrucción del recuerdo y la unión con el amado. El pasaje comienza de esta manera:

Ora te envuelva funesta Dejanira en su túnica homicida o aspires la onda casta del incienso de los sueños. Siempre te veo

\footnotetext{
${ }^{61}$ En mi opinión, parece que no está claro si el tema de esta carta trata de la muerte como realidad, o como metáfora del olvido, duda que surge a partir de la lectura de las cartas 84, 85, 86, en las que Borrero no explica ni aclara el motivo de su retractación de la Carta 76.
} 
grande. Siempre te veo mío... Entre los brazos de la misma «Proserpina» eras mío...Porque sus brazos caldearían el corazón de tu pecho pero el corazón de tu alma era un santuario demasiado íntimo para que ella penetrara en él profanándolo. Ha estado cerrado aguardándome y yo penetro en él confiadamente. Me acerco al altar y con mis manos enciendo la sagrada lámpara que no ha sido jamás encendida por otra mujer. [...] iQué dulce impresión me produce ese ambiente de tranquila pureza que se respira en el interior de tu alma!

Borrero aquí contrasta dos escenarios: el mitológico y carnal ("el corazón de tu pecho") y el espiritual y sagrado ("el corazón de tu alma"). Dentro de la estética modernista, la mitología así como las parábolas y los relatos bíblicos dieron universalidad a los temas hispanoamericanos. Con ello se intentaba encontrar la esencia nacional dentro de la esencia universal, búsqueda que propiciaría luego el desarrollo de las vanguardias. Así aparecía en los poemas de Casal "Prometeo", "Hércules ante Hidra", así como también en "Salomé" y "La muerte de Moisés". ${ }^{62}$ En la carta de Borrero, los motivos mitológicos sirven para confinar la evocación del recuerdo a un contexto imaginario que está más cerca del artificio que de la realidad, además de que confirman la hegemonía del sujeto sobre los sentimientos del interlocutor: "Siempre te veo mío".

\footnotetext{
${ }^{62}$ Compárese con los temas mitológicos y bíblicos del "Cuento áureo" (1899) de Manuel Díaz Rodríguez, "El triunfo de Salomé" (1899) de Enrique Gómez Carrillo "Salomé" (1904) de Froilán Turcios y "Las vértebras de Pan" (1914) de Eloy Fariña Núñez.
} 
Obsérvese que en el pasaje anterior la presencia del sujeto ocurre en un tiempo mítico anterior al recuerdo ("ha estado cerrado aguardándome"). La escritora se acoge a una alegada predestinación que altera el devenir del tiempo dentro del texto, posesionándose de un pasado que no le pertenece. Inmerso en el ambiente mítico del santuario, el sujeto lírico oficia frente al altar encendiendo "la sagrada lámpara". Los ambientes y los motivos litúrgicos llegaron a formar parte de la estética de fin de siglo. Aunque el artista no pretendía con ello restaurar los valores espirituales, mostraba su fascinación por el ornamento de una religiosidad decadente. Según Schulman, la incertidumbre finisecular convertía al artista "en un testigo visionario y, a la vez, en el historiador de desconocidas experiencias", inclinándose así hacia "el sondeo síquico, la inclinación hacia la profecía [...]" (El proyecto 17). La perplejidad del artista marginado y perdido en la experiencia postcolonial lo llevó a transferir su angustia existencial a latitudes desconocidas, o a contextos imaginarios como el del exotismo espiritual de esta carta.

Hasta este punto, el texto se presenta como una relación de imágenes sugestivas mantenidas por un diálogo que gradualmente se disuelve. Pero a partir de aquí, el entorno de la capilla deja de ser un accesorio textual, y es entonces cuando la artista se entrega al éxtasis de su visión:

Allí en la oculta capilla flota el espíritu de la muerte amada que yo también amo!. Me parece oír una voz insinuante que me dice: «hermana, ¿estás aquí?...» «Ven! Lo amarás conmigo!» y siento en mi frente la ráfaga helada de su aliento refrescándola con su misteriosa canción. He cerrado la puerta del santuario. 
Estamos solos tú yo y la sombra de ella. Me arrodillo ante el Ara y ocultando la frente entre las manos pienso y reflexiono»». Poco a poco el pensamiento se torna en quimera, la quimera en ensueño, el ensueño en plegaria... y mi oración sube como una espiral de mirra a perfumar el ídolo que ocupa la urna. Con la cabeza abatida no por la tristeza sino por la emoción de profunda paz que se respira en el misterioso santuario, permanezco mucho tiempo sumergida en mí misma. Estoy en tu alma. Estoy en ti....

Nótese que el sujeto lírico justifica su presencia respondiendo a la invitación, "ven, lo amarás conmigo". Lograba el acceso a aquel pasado vedado por la inmutabilidad del curso del tiempo, por una vía espacial (“Estoy en ti”) y no temporal. La oración, "He cerrado la puerta del santuario", señala el cierre estructural que da paso al segundo momento narrativo: la deconstrucción del recuerdo.

El recuerdo, representación de la amada muerta, ahora queda fragmentado en los vagos efectos que de él se perciben: "me parece oír"; "la ráfaga helada de su aliento"; una “misteriosa canción". Reducido a sensaciones, el recuerdo pierde realidad y comienza a desvanecerse. La carta continúa:

Cerca de mí una sombra vaporosa va y viene como un pétalo mecido por la ráfaga del céfiro. Es el recuerdo de la pobre muerta. Yo comparto con ella gustosa el dominio de tu alma $[\ldots]$. ¿No la amaste? Y sobre todo ¿ no te amó? pues yo también la amo. Los vulgares celos profanarían esa sombra 
sagrada [...] Ahora la siento pasar junto a mí tan cerca que el roce de su sudario lo he sentido en mi frente. Quisiera poder asirla besarla pagarle con caricias el amor que tuvo....! Pero no puedo. No es más que un recuerdo y su muerte es mi dicha”.

Para evitar que su texto se convirtiera en una versión grotesca de la muerte, la estrategia de Borrero consiste en representar el recuerdo de la amada por medio de recursos acústicos y táctiles, pero no visuales. Nótese que esa presencia permanece fuera del alcance visual del lector: "allí oculta". De haberlo hecho, Borrero corría el riesgo de distorsionar, y tal vez profanar, una imagen forjada en el sentimiento a través del recuerdo. No obstante, era necesario redefinir ese recuerdo, para que el lenguaje poético de su texto lo despojara de su influjo.

La presencia de la muerta se representa vagamente con efectos acústicos y con la aliteración que resulta de la combinación de las palabras "siento", "cerca", "roce", "sudario", "sentido". Acerca de la tendencia modernista a trabajar con los sonidos y la musicalidad, Menton explica: "La base del estilo modernista era [...] su aliteración, su asonancia, sus efectos onomatopéyicos y su ritmo constituían una sinfonía que deleitaba al oído" (152). A propósito del ritmo, nótese además en este pasaje la ausencia de las comas entre las palabras "asirla", "besarla" y "pagarle", manierismo recurrente en Borrero, que en este contexto sirve para impartir celeridad a la frase, tal vez para representar la futilidad del recuerdo.

Sin embargo, hacer desvanecer una memoria provoca un vacío emocional que la artista colma en el texto con recuerdos artificiales, memorias virtuales de realidades 
imaginadas. Obsérvese ahora el tercer y último momento narrativo de la carta de Borrero:

El oleaje de la pasión carnalmente ardorosa expira al umbral, detenido por un blanco guardián que vigila la entrada: ¡El ensueño! Y dentro en hermosa nupcia se adoran nuestras almas en la penumbra soñadora del santuario. Allí en la atmósfera pura de nuestro asilo se realiza la unión de lo que yo llamo los sexos del alma, unión más estrecha y mil veces más duradera que la degradante posesión corporal. Y mientras nuestras almas se desposan sobre las alas de una oración fervorosa la sombra de la muerta gira en torno nuestro y yo siento el soplo débil de su aliento acariciarme con su caricia helada en tanto que su voz insinuante me dice muy quedo: «hermana ¿estás aquí?»...... Yvone y Juana.

Aquí se realiza una ingeniosa trasmutación de imágenes, porque la unión de las almas se representa como negación del deseo, no obstante el lenguaje sensual con que se inscribe. Juana misma se definía como "una sensualista del espíritu" (EI 198), condición que Francisco Morán explica de la siguiente manera: "la importancia y complejidad de las representaciones del erotismo en Juana Borrero, la sitúan definitivamente fuera de la órbita estrictamente romántica, y nos la muestran, en cambio, no en los márgenes, sino en el vórtice de la experiencia modernista" (La pasión xxiii). Podríamos añadir como punto de referencia entre dos estilos y períodos literarios, que el sensualismo espiritualizado de Borrero contrasta con el romanticismo religioso de Avellaneda, quien no concebía ni 
representaba del mismo modo la conexión espiritual entre Cepeda, su amante, y un “ministro del cielo" (Avellaneda, Epistolario 49).

La síntesis espíritu/deseo como en esta carta, aparece en el modernismo cuando el artista intenta representar la belleza desde toda perspectiva posible. Ese erotismo era un deseo de autodefinición que desafiaba la moral burguesa. ${ }^{63}$ Como se había dado en el arte medieval, la anagogía (literalmente "llevar hacia arriba") era el estado de elevar al alma para unirse con el Otro (Eco, Historia 330). Juana sustituye la unión con el Ser Supremo con la del Amado, unión que ilumina su razón. Su arte, como "a lo divino", es el afán de posesión anímica hacia la emancipación del espíritu que ya encontrábamos en Santa Teresa: "ha hecho a Dios mi cautivo,y libre mi corazón". 64 Señalemos que el matrimonio espiritual es tema frecuente en estas cartas, en particular de la 39, en donde Juana exige y logra que Carlos Pío se comprometiera a un matrimonio casto. Nos detenemos en este punto, a fin de poner en contexto la antítesis espíritu y deseo como fórmula recurrente del Epistolario. Esto nos ayudará a comprender la motivación y las estrategias de composición tras el discurso intimidatorio que caracteriza su escritura.

Según explica Vitier en el prólogo de las cartas, el matrimonio casto al que aspira Borrero proviene de un "milenario maniqueísmo trasplantado a las cortes provenzales" (23). El tema cautivó primero a los románticos y luego a los modernistas, aunque la idea del amor imposible fue una interpretación romántica del arte medieval (Eco, Historia de la belleza 167). La dama cantada por los trovadores provenzales y la literatura del ciclo bretón del siglo XI era casta y la vez esquiva: mientras más inalcanzable, tanto más

\footnotetext{
${ }^{63}$ Ver introducción de Francisco Morán a su libro La pasión del obstáculo, (xix, xx) en donde explica el erotismo como forma de destrucción en Borrero.

${ }^{64}$ Del poema de Santa Teresa, "Vivo sin vivir en mí".
} 
deseada. Tal sentimiento de frustración desarrollaba en los amantes un desprecio a los deseos carnales, concepto que evolucionó en la idea de amar por amar, o el arte por el arte de los modernistas, es decir, el afán de representar al objeto por su belleza intrínseca, más allá de su función. ${ }^{65}$ Despojado de su función, el amor platónico se intensifica en deseos de posesión del objeto, lo que termina convirtiéndose en pretensiones de grandeza moral y castidad.

La grandeza moral y el matrimonio casto llegaron a formar parte de los mitos del Epistolario, así como Borrero explica: "somos seres excepcionales... Hemos roto el vínculo del cuerpo y el alma, hemos quebrantado el yugo abrumador y degradante de las solicitaciones corporales..." (EI 155). En la cultura judeocristiana, la castidad dentro del matrimonio es una virtud sinónimo de fidelidad. Pero lo que Juana propone en la Carta 76 ("los sexos del alma") es un estado de castración anticipada, que dentro de este contexto parece representar una prueba de sumisión emocional. ${ }^{66}$ La narrativa decimonónica había presentado otro aspecto de la misma idea como arquetipo literario: la devoradora de hombres (Zavala, Breve historia I, 64). Esta era la imagen de la mujer que representó Casal en su poema "Neurosis", imagen que a veces inspiraba a Juana en algunos de los pasajes de sus cartas: "te acariciaría hasta con la punta de un puñal" (EI 376).

Tal vez por su propia naturaleza, o por la influencia de los textos de la época, Juana reaccionaba ante el deseo con una alegada forma de grandeza moral. Por ejemplo,

\footnotetext{
${ }^{65}$ Recuérdese la búsqueda de la belleza idealizada en mujer en la novela De sobremesa, de José Asunción Silva (1865-1896).

${ }^{66}$ Salvando la distancia literaria, un tema similar aparece en La Regenta (1884), de Leopoldo Alas, "Clarín", en donde el confesor de la protagonista le exige un acto de constricción público, con el que intenta apropiarse de su voluntad emocional.
} 
piénsese en el tema del poema de Casal "Cuerpo y alma": "Que la alondra no viva junto al tigre, $\backslash$ Que la rosa no viva junto al cerdo". Esto constituía tanto en Casal como en Borrero una tensión entre castidad y deseo, que tal vez provocaran los intensos estados emocionales que ella describe: "Esta ansia extraña que nos arrastra a lo desconocido es la que engendra la demencia en las almas soñadoras!” (EII 32). La negación del deseo se evidencia en los comportamientos destructivos que se advierten en la literatura femenina decimonónica. De allí surge, según Evelyn Picon Garfield, el "desinterés en el placer sexual de la virgen" (134).

La idea del desposorio de las almas o el matrimonio casto de la Carta 76 aparece también en algunas novelas femeninas del siglo XIX inglés. Elaine Showalter explica: "In choosing a sexless marriage, she is at least partly acting out her own terror of passion. [...] repressed sex-antagonism in human relationships, which women had to project into a variety of destructive behaviors because they were afraid to confront its true source" ( $A$ literature of their own, 207, 212). La proyección de tales comportamientos tal vez era una reacción a las ideas pseudo-científicas que intentaban controlar el comportamiento femenino, cuando en el siglo XIX se advierte con recelo la participación de la mujer en la vida social y cultural. El libro The Madwoman in the Attic explica:

Such connections between female pleasure and female power, between assertive female sexuality and assertive female speech, have been tradicional ones. [...] the relationship between sexuality and female Genius becomes virtually causal: female genius triggers uncontrollable sexual desires, and perhaps, of female genius. That Genius and sexuality are diseases in 
women, diseases akin to madness, $[\ldots](568,569)$.

Cuánto de este comportamiento en Juana es asimilación o esencia, es debatible, pero está más allá del enfoque de este estudio. De todos modos, lo importante en Borrero es el reconocimiento y la representación del deseo a través de su negación. En nuestra opinión, este procedimiento se justifica en dos direcciones: le da licencia para escribir sobre lo prohibido y le sirve de herramienta expresiva con la que se inscribe en la corriente temática y estética de la época.

Paradójicamente, la ostentación de castidad (que en la carta de Borrero contrasta pero al fin se hermana con el carácter sensual del Epistolario) tenía un atractivo erótico para el Otro que tal vez Juana intuyera. La literatura escrita generalmente por hombres había creado un mito sobre el misterio femenino y su sensualidad (De Beauvoir 152, 155). Estas ideas encontradas surgían del temor a ser dominado en base al amor, trasfondo que en la literatura aparece inscrito en el lenguaje del poder, ya en la forma del amor cortés medieval, o en el maniqueísmo cultural decimonónico. La originalidad en Borrero consiste en apropiarse de tal recurso, tradicionalmente ocupado por el hombre, para influir en la voluntad física y anímica de su interlocutor.

Sin embargo, aunque en estos pasajes Borrero se expresa dentro de la corriente poética del momento, era de esperar que con su lucidez intelectual y el conocimiento científico que aprendía de su padre desarrollara sus propias ideas acerca de la sexualidad femenina. Por ejemplo, en un artículo publicado en El Fígaro del 24 de febrero de 1895, con el título "Pensamientos", escribe: "La Naturaleza, nuestra madre inconsciente, obedece, dentro de un período de su existencia a leyes inmutables: su funcionamiento constituye el grandioso conjunto del equilibrio universal. No ven este equilibrio los 
miopes que no abarcan la totalidad del vasto escenario. [...] la conciencia está en nosotros y no en ella" (en Morán, La pasión 104). De lo anterior se entiende que Juana comprendía y aceptaba el deseo como función humana que debía estar sujeta al ejercicio de la conciencia. No obstante, la sensualidad espiritualizada que como negación al deseo asoma en el Epistolario parece justificarse en función del discurso del poder que lo caracteriza.

En la conclusión de la Carta 76, el recuerdo de la amada muerta deja de asediar al artista y a su interlocutor. El soplo de su aliento ha pasado a ser "débil", y el sonido de su paso ya "muy quedo". La sombra revolotea inútilmente en torno a unas almas que se desposan, mientras que el sujeto lírico se apropia del lugar que una vez ocupara el recuerdo: "Hermana, estás aquí?...". Borrero ha intentado por medio del arte de dar cierre a un capítulo sentimental de la vida de Carlos Pío, por lo que al firmar, "Yvone y Juana", se hace reconocer como artista y también como mujer. Tres días más tarde, esta carta le serviría de inspiración para componer el verso que encabeza la Carta 81: "De la capilla desierta/En el ambiente sombrío/Flota el alma de la muerta/Rondando el altar vacío/De la capilla desierta...". Contrastaba con el poema de Casal "Amor de claustro", en el que la heroína, con remordimiento y espanto, creía ver en el Cristo la imagen del amado.

Nótese cuán intuitivamente Borrero en su carta transita por las vías que la conducen a la unión con el Amado, así como aparecía en la literatura mística. "Poco a poco", había recorrido la vía purgativa al desprenderse de las bajezas humanas (los celos) y entregarse a la meditación ("el pensamiento se torna en quimera, la quimera en ensueño, el ensueño en plegaria"). Así encontraba la luz y "profunda paz" de la vía 
iluminativa de su éxtasis creativo. Ese "llegar" ocurría por la fusión de las dimensiones espacio y tiempo que sólo eran posibles en virtud del Arte. El clímax surgía con la unión con el Amado, el "estoy en ti” de su vía unitiva.

Borrero logra la armonía estructural de la Carta 76 por medio de su diseño y organización. La cohesión temática y estilística con que fluyen sus tres momentos narrativos (las reflexiones del sujeto y la plenitud artística, la deconstrucción del recuerdo y la unión con el amado) se logra por las identificaciones y reconocimientos entre el enunciado de la carta y un ingenioso sistema de símbolos. Las dificultades de representación, planteamiento y solución del problema (la deconstrucción del recuerdo), se resuelven trayendo el tema a un contexto pseudo-religioso que, no obstante, se inscribe en el discurso del deseo.

Sin embargo, Juana presintió que la confesión de Carlos Pío que motivara la escritura de esta carta no la abandonaría, así como lo explica: "La obsesión de tu confidencia es tenebrosa como el cuervo simbólico y se ha posado sobre mi alma blanca como Minerva para no alejarse de allí nunca más" (EI 278). Seis meses después y a sólo unos días de su muerte, un extraño incidente trajo de vuelta este escabroso tema. Carlos Pío, sin aparente explicación, copia y envía a Juana una carta que guardaba de aquella mujer. A su lectura, Borrero respondía con la pavorosa Carta 218, en la que escribe: "Este fantasma insomne que aún te posee ha amargado algunas de mis noches".

Por qué Carlos Pío provoca los celos de Juana estando ella a punto de morir permanece en el misterio. Tal vez él, al igual que antes lo había hecho Cepeda, proponía 
temas de escritura como parte de un sinuoso patrón de acción y reacción epistolar. ${ }^{67} \mathrm{De}$ ser así, iba tras el espíritu decadente del héroe finisecular y del placer voluptuoso que aparece, por ejemplo en el cuento "Pareja exótica" (1914) de Froilán Turcios ${ }^{68}$. De cualquier manera, la posesión absoluta seguiría siendo el móvil tras el discurso intimidatorio de un epistolario que albergaba y promovía una rara dinámica sentimental.

\section{Innovación narrativa de la escritura de mujer: el Epistolario de Borrero y la literatura fantástica.}

Aunque fueron pocas las novelas que se escribieron durante el modernismo, el cuento se cultivó por casi medio siglo y pervivió junto al romanticismo, el realismo y el naturalismo (Menton 151). Sin embargo, el cuento modernista rechazó el melodrama romántico, el cientifismo naturalista y el lenguaje del realismo, ya que aquéllos no se ceñían a la renovación estética que se trazaron aquellos artistas. Prefirieron hurgar en los mitos universales, así como también en lo ilógico, lo irracional y lo sobrenatural, como mejor representación de sus inquietudes. Sus búsquedas existenciales aceleraron la ruptura con lo superficial y propiciaron el encuentro con las esencias que serían el fundamento de las vanguardias. Con relación a lo anterior, Enrique Marini-Palmieri se pregunta: "Fue ello tarea del modernismo: distanciarse para comprender mejor?" (19).

La inclinación por el ocultismo y las formas de espiritualidad decadente eran una reacción del artista de fin de siglo a la crisis espiritual. Buscaba en ellos, no sólo muletillas espirituales, sino también propuestas temáticas para sus creaciones literarias

\footnotetext{
${ }^{67}$ Avellaneda, Epistolario 143

${ }^{68}$ Froilán Turcios (1874-1943) fue escritor, periodista y político hondureño. Turcios cultivó el género del cuento. Sus relatos se caracterizan por el preciosismo y los finales inesperados.
} 
(Jiménez y Morales 17, 18). Es así que proliferaron los relatos de fenómenos raros y de individuos enajenados, héroes o testigos narradores que con frecuencia era el mismo escritor. Por ejemplo, Esteban Borrero, padre de Juana, publicó el primer libro de cuentos de la literatura cubana, Lecturas de Pascuas (1899). Su cuento "Calófilo" (1879) narraba las confesiones tortuosas de un sujeto atormentado. Tendencias decadentes y relatos fantásticos aparecían en los cuentos "La última ilusión" (1893) de Casal y en "El caso de la señorita Amelia" (1894) de Darío.

Sin embargo, no se recogen relatos significativos escritos por mujeres en ese momento literario en el que el cuento proliferaba en Hispanoamérica. Por ejemplo, no hay representación femenina en las antologías de José Olivio Jiménez y Carlos Javier Morales (1998), ni en la de Enrique Marini-Palmieri (1998), ni tampoco en la antología de cuentos fantásticos modernistas de Dolores Phillipps-López (2003). Seymour Menton incluye en la séptima edición de su antología del cuento hispanoamericano (2003) cuatro cuentos escritos por mujeres, pero éstos pertenecen a las vanguardias. Parece ser que la mujer, mal comprendida y peor representada, prefirió el lenguaje metafórico de la poesía para describirse a sí misma y expresar sus necesidades, aspiraciones y deseos.

No obstante, no sería arriesgado afirmar que Juana Borrero cultivó el cuento mientras escribía cartas, aunque éstos habría que localizarlos e identificarlos entre sus páginas. Una ventaja de esos relatos es su síntesis narrativa y simpleza estructural, características que parecen ser consecuencia de las limitaciones obvias del espacio epistolar. De todos modos, sus narraciones aparecían libres del "barroquismo abrumador" y de los "derroches verbales" que aquejaron algunos cuentos modernistas (Jiménez y Morales 10). Los relatos de Borrero surgían al contar la experiencia 
alucinante de una noche de insomnio, o la angustia tras una pesadilla, o simplemente aparecían al bosquejar un proyecto de escritura. Algunos cuentos, trazados en menos de cien palabras, se ajustaban a la definición más elemental del género: narración breve, cuyos elementos contribuyen a producir un solo efecto (Menton 8). De acuerdo a lo anterior y para el propósito de este acápite, hemos identificado algunos relatos en el Epistolario, y dentro de esa selección nos enfocamos en dos temas principales: la apropiación del discurso masculino en la representación de la mujer, y la función del personaje/narrador en interacción con el lector real y el narratario.

Un brevísimo relato de Borrero aparece en la Carta 102, escrita desde Larrazábal, con fecha del 5 de septiembre de 1895. Juana lo presentaba como un proyecto de cuento, pero al ponerlo por escrito, su relato aparecía como un texto completo, no obstante su naturaleza ambigua. A la carta la motivaban los celos, la "mirada hembra" con que se imaginaba que otras mujeres veían a Carlos Pío. Nuevamente él le hablaba de otras, por ejemplo de aquélla que según Juana "tiene el descaro sacrílego de llamarse "María”".

El texto, presentado como el bosquejo de un cuento, se titularía «Diablesa», y lee así:

El asunto es bello y humano. Al pie de una escalinata de mármol, una mujer hermosísima se despide del que fue hasta esa noche su amante. Mientras le alarga su mano aristocrática y pródiga, ciñe el otro brazo al cuello de otro, «amante amado», del preferido. Lejos, al través de las arcadas de follaje suena la música y cerca, bajo el techo de los amplios salones vibra discordante el himno de la orgía. 
Léase este bosquejo de cuento como un microrrelato, y el lector encontrará en 73 palabras una idea completa y acabada, que por su brevedad y ambigüedad, se abría a la interpretación del lector. La aparente ausencia de acción narrativa encuentra un paralelo (salvando las distancias del tiempo y los reajustes estilísticos y temáticos) con el microrrelato "El pisapapel” (1922) del escritor cubano Alfonso Hernández Catá. Aunque el microrrelato se popularizó durante las vanguardias, Rubén Darío y otros modernistas lo usaron como fórmula narrativa. La idea provenía de la tradición oral y la parábola, y ya aparecía en El Conde Lucanor (Don Juan Manuel, 1335), en el Decamerón (Giovanni Boccaccio, 1351) y en los bestiarios. El microrrelato es género un híbrido y su autonomía depende del lector, quien ve en cada pequeña historia un texto independiente del cuerpo literario que lo contiene. Imprescindible en su escritura es el título integrado al texto, como en "Diablesa", término con el que no sólo describe a la mujer, sino que también contrasta con su introducción: "El asunto es bello y humano". No obstante, el tema de Borrero era subversivo, ya que atentaba contra los valores morales de la sociedad decimonónica.

Este breve relato tiene un interés especial en la historia de la incorporación de la escritora de fin de siglo a la literatura: la apropiación del discurso masculino en la representación de la mujer. La imagen femenina de la literatura modernista escrita por hombres estaba atada a estereotipos propuestos por la sociedad burguesa: la madre abnegada, la mujer-sueño como estatua marmórea, y la devoradora de hombre, todas de belleza excepcional. Pero la mujer de este relato era la mujer del arte decadentista quien, según Umberto Eco, sólo podía ser vista en toda su fascinación "si está referida a un modelo artificial, a su progenitora ideal en un cuadro, en un libro, en una leyenda" 
(Historia 342). ${ }^{69}$ La femme fatale (“erotismo negro”, según Jiménez y Morales 23) aparecía en el arte decadentista de las dos últimas décadas del siglo era un objeto de arte como la "seductora y extraña mujer" del "Cuento de pascuas" (1911) de Rubén Darío, como "Diablesa".

El arte decadentista de las últimas dos décadas del siglo XIX había tomado su nombre del término despectivo con que la crítica denominaba a los "poetas malditos", a propósito de la publicación del mismo nombre (1884) de Charles Baudelaire. Su arte se pronunciaba en contra la cultura burguesa y abandonaba la estética pictórica parnasiana a favor de la musicalidad, así como aparecía en "Diablesa". La crítica luego dio una aplicación más amplia al término, para identificar a todo arte que se oponía a la norma. Borrero, burla a los burladores de los "decadentes", a propósito de un comentario sobre crítica literaria: "Y quiénes son los decadentes? Yo no los veo. Yo los veo subir, subir siempre, unos por la escala del Arte otros por la del Amor, y algunos como tú suben por las dos a un tiempo. ¡Oh los «ascendentes»! [...] Además, el símbolo me atrae. Es la solución de tantos problemas! para mí es algo sagrado como la religión como el arte mismo" (EI, 357). Esa era una crítica contra del director de un periódico, "El Progreso", de quien dice: "Cada inteligencia rechaza lo que no entiende", lo que muestra cuán experimental e innovador eran las manifestaciones artísticas del fin de siglo.

La primera generación de escritoras modernistas se apropió del discurso masculino y de la imagen femenina representada en ese discurso para componer poesía. Así aparece en "El cisne”, del poemario Los cálices vacíos (1913) de Delmira Agustini y

\footnotetext{
${ }^{69}$ Compárese la carta de Juana con las muestras de literatura decadentista que cita Eco en las páginas 343 a 345 del mismo libro.
} 
también en El último amor de Safo (1902) de Mercedes Matamoros. La mujer-joya ahora era el epítome de la mujer transgresora desde la perspectiva femenina, mujer descrita por mujer, echando mano al lenguaje masculino para insertarse en el discurso de la modernidad. ${ }^{70}$ Sin embargo, lo innovador en Borrero era inscribirlo en la prosa, ya que no contaba con modelos literarios de una tradición femenina dentro del género.

Pero "Diablesa" no era un relato fortuito en estas cartas. El tema reaparecía con variaciones en la Carta 120 del 27 de septiembre de 1895, que titulaba "Misiva extraña". Nos limitamos a describir su estructura (su extensión total es de 2 páginas) para introducir lo que Carlos Javier Morales describe como "la reincidencia en el relato de experiencias raras, extrañas o anormales" que se dio durante el modernismo (234). Este era el relato de "un desfile mágico" de bellas mujeres fantasmales que Juana dice haber visto en una madrugada de insomnio. Captaba este momento de fatiga mental para componer, lo que equivalía a provocar y excitar los sentidos para la inspiración artística. Ella explica: "Sí, me gusta refinar la sensación hasta lo increíble y entonces experimento los inefables placeres de los sueños incomprensibles" (EI 198). Una idea similar proponía Arthur Rimbaud (1854-1891), el escritor francés, acerca de los motivos de inspiración artística: "El poeta ha de hacerse adivino a través de un largo, inmenso y razonado desorden de todos los sentidos. [...] Llega a lo desconocido y cuando, descompuesto acabe por perder la comprensión de sus visiones, ¡las ha visto!” (en Eco Historia, 336).

\footnotetext{
${ }^{70}$ Véase "La mujer como enfermedad y muerte en el proyecto modernista: Notas para un estudio", Catalina Pérez-Abreu, Espéculo. Revista de estudios literarios. Universidad Complutense de Madrid. http://www.ucm.es/info/especulo/numero 30/mujermod.html.
} 
El relato del desfile fantasmal de Borrero contenía las características básicas del cuento modernista: subjetividad del narrador ("En una noche como ésta debió penetrar el cuervo fúnebre en la alcoba y en el alma del visionario Poe...); mitificación de la realidad ("Han pasado ya todas? Reinas y vírgenes, madonas, castellanas, novicias, querubes, diabólicas, seres etéreos y mujeres hermosas como esculturas"); y justificación del fenómeno raro ("Abro los ojos y me encuentro en mi lecho con la cabeza oculta entre Gemelas..."). Persistía el diseño circular de la estética de Borrero ("La noche se ha despejado. La luna, una luna pálida y enferma se oculta y filtra su luz moribunda hasta mi habitación dibujando en el suelo de mármol las franjas oscuras de las persinas"), así como también la intención intimidatoria ("Estoy viendo todo esto [...] Es mi pasión la que me dicta estas frases").

En aquel desfile, la belleza femenina estaba representada desde dos vertientes de la estética finisecular: el prerrafaelismo, corriente pictórica nacida en Inglaterra a mediados de siglo, y el Art Nouveau, aparecido en Bélgica y Francia durante las dos últimas décadas del siglo. En ambas tendencias la mujer era la representación óptima de la belleza, imágenes que se materializaron con el advenimiento de la fotografía alrededor de $1839 .{ }^{71}$ Aquel desfile fantasmal estaba realizado con una atmósfera preciosista que los modernistas componían a partir de la acumulación del ornamento: "los cabellos a la griega y en el cuello un collar de gotas de sangre”. Según Menton, esta característica se había dado en la literatura, una vez que los ambientes parnasianos superaron "su fría impasibilidad por la potencia emocion al del símbolo" (40).

\footnotetext{
${ }^{71}$ La foto de Maria Cay vestida de japonesa inspiro el verso "Kakemono" de Casal, y también y también "Para la misma", de Rubén Darío.
} 
"Diablesa" y "Misiva extraña" representan un hito en la narrativa del Epistolario. En ambos relatos prevalece la influencia romántica en cuanto a su naturaleza fantástica. Sin embargo, se incorporaban elementos de la estética finisecular, a saber, el preciosismo y la representación de la mujer como objeto de arte. Las mujeres de Borrero tenían una belleza ambigua, la belleza maldita que las identificaba con el símbolo que resumía su esencia. Como espectros seductores, dejaban en el lector la ambigüedad de su identidad: ¿inocentes o perversas?, ¿pérfidas o santas?

Para sobrellevar el spleen de fin de siglo y procurarse sensaciones que luego incorporarían a sus textos, algunos artistas experimentaron con los excesos y otros tipos de comportamientos aberrantes. El uso de estupefacientes llegó a ser parte de la creación artística, como advierte Juana a Carlos Pío en contra del uso del haschisch (EI 273). Aunque ella misma consumía opio, morfina y otras drogas como remedio a sus enfermedades, no parece que buscara en ellos motivos de inspiración (Ver cartas 62, 75 y 84). ${ }^{72}$ Sin embargo, los episodios de insomnio, así como los sueños y su interpretación, fueron con frecuencia motivos de escritura para sus composiciones. ${ }^{73}$ En general, la intensificación de las sensaciones, fueran cuales fueren las causas, se sumaron al interés del artista de fin de siglo por los fenómenos insólitos, y se convirtieron en temas y fórmulas de presentación. Dolores Phillipps-López observa: "Modernidad y fantasía se

\footnotetext{
${ }^{72}$ En la Carta 51, Juana explica el fenómeno de la sinestesia: "ver sonidos". La canción de la morfina" de Casal contiene la misma idea: "Percibe el cuerpo dormido/Por mi mágico sopor/Sonidos en el color,/Colores en el sonido".

${ }^{73}$ Sin especular sobre ese texto, más de cincuenta años antes de formularse la teoría del REM (teoría sobre el movimiento rápidos de los ojos de 1952), la "animación de las pupilas ocultas bajo los párpados") en la Carta 49.
} 
solidarizan, y en esta medida y contexto se consolidó significativamente en Hispanoamérica la narrativa fantástica” (32).

El aspecto fantástico de la literatura finisecular fue un rasgo genuinamente moderno. Sin profundizar en la complejidad del tema, luego que en 1970 Tzvetan Todorov trazara el deslinde de la literatura fantástica, entre lo maravilloso y lo insólito, otros críticos advirtieron la existencia de relatos cuya composición híbrida desafiaba las definiciones genéricas, así como también identificaron relatos fantásticos en textos no canónicos, es decir, en documentos no vinculados a la cultura judeocristiano occidental (Phillipps-López 13, 15). Valiéndonos de tal observación y aplicándola al tema que nos ocupa, intentamos demostrar que existe una narrativa fantástica entre las páginas del epistolario de Borrero, textos en donde el carácter híbrido de lo fantástico es el resultado de la naturaleza epistolar de su composición.

El romanticismo hizo una notable contribución a la literatura modernista, al aportar una variedad de temas y situaciones, como fueron los temas de la locura, las escenas macabras, los sueños y las pesadillas. Por ejemplo, era indiscutible la influencia de Edgar Allan Poe (1809-1849) en Borrero. Juana conocía su poesía, así como también su narrativa, según aparece en las cartas 46 y 205, respectivamente. ${ }^{74}$ De estos relatos, la escritora pudo haber aprendido que el escritor norteamericano sorteaba la técnica del “susto" y de la sorpresa del cuento fantástico del romanticismo. En su lugar, optaba por presentar un aspecto ambiguo de la realidad a partir del estado psicológico del personaje

\footnotetext{
${ }^{74}$ En la Carta 205, Juana aparentemente confunde el cuento "El gato negro"de Poe con el poema de Baudelaire, "Los gatos", que pertenece a su poemario Las flores del mal (1857).
} 
(Guarner 9). ${ }^{75}$ En la Carta 120 citada anteriormente, Borrero hacía una referencia directa al "visionario Poe", y tras narrar su extraña experiencia, explicaba: "He sentido esta noche el desasosiego que precede a la locura". Ese episodio tomado de la vida real e incorporado al texto plantea la idea de que lo fantástico puede presentarse desde dos vertientes: como tema o como técnica. En el caso anterior, lo fantástico surgía al narrar desde el punto de vista de un sujeto enajenado.

De acuerdo con Seymour Menton, durante el modernismo la prosa "dejó de ser sólo un instrumento para narrar un suceso" (152). Así aparecía en la Carta 104 que ahora nos ocupa, en donde Borrero se disponía a narrar un sueño. Escribía desde su retiro en Larrazábal, en donde lamentaba la separación de Carlos Pío y la ausencia de sus cartas. El ámbito político-social aparecía igualmente lúgubre. Cuatro meses antes había muerto Martí, y por aquellos días el Ejército Libertador se reunía en Jimaguayú para nombrar a los dirigentes de la República en Armas. Tal inestabilidad política, aunada a la angustia familiar y sentimental, debió de provocar el extraño sueño que la artista relataba con fecha del sábado 7 de septiembre de 1895. A pesar de que las imágenes de los sueños con frecuencia emergen difusas e imprecisas, el suceso narrado aparecía con asombrosa precisión. Esto se debía al uso de datos concretos que precisaban el entorno y las circunstancias de aquella visión onírica. Las percepciones concretas aportaban verosimilitud a las imágenes, mientras que la evocación del recuerdo las ordenaba, proceso lógico y coherente que debía mediar entre la razón y el lenguaje.

\footnotetext{
${ }^{75}$ En "The Fall of the House of Usher", lo raro se debe a la condición nerviosa del personaje, mientras que el evento insólito se presentaba como coincidencias de la realidad. Poe también fue precursor del relato detectivesco que más tarde reemplazó al relato de fantasmas (Todorov 49).
} 
El texto de Borrero consta de menos de 200 palabras y su composición se compone de dos núcleos narrativos: la atmósfera descrita desde la perspectiva del sujeto y el evento que propicia el desenlace. La narración comienza de la siguiente manera:

Hacía un mes que no te veía. De repente me faltaron tus cartas. Me faltó la luz... poco después me faltaste tú. Un día supe que te habías casado...Averigüé la dirección de tu casa y una noche, mientras tú y ella comían descuidados me introduje en la alcoba y me oculté detrás de los lambrequines. Allí esperé. Con los labios trémulos de angustia y entre los dedos un puñal pequeño, especie de daga que días antes me había regalado Rosalía. Así te sentí llegar y escuché el roce de su falda sobre las alfombras. Jamás mientras viva se me olvidará aquella mujer, aquella desconocida que no existe y que caminaba apoyada en tu hombro.

En el relato fantástico, la atmósfera tiene una función tanto o más importante que lo narrado. De manera sucinta, Borrero compone una atmósfera inquietante a partir de la ansiedad del sujeto. Nótese cómo la selección de palabras y las frases contribuyen a este propósito: "de repente me faltaron, "labios trémulos de angustia", "me oculté detrás de los lambrequines". Nótese además que la escritora abre un paréntesis descriptivo al referirse a la daga, único objeto en ese ambiente que parece adquirir una realidad inusitada.

Otro aspecto que contribuye a la creación de la atmósfera como marco contextual es el registro de los estímulos percibidos por el sujeto: el sonido de la falda sobre la 
alfombra, la lentitud de los movimientos de la pareja que come. A esto se añade su ansiedad, representada por la inquietud de sus movimientos mientras acecha. Aparecen también otros elementos de composición, tales como los verbos en pretérito imperfecto ("hacía", "comían", "había”) y los modalizadores ("me faltó la luz", "trémulos de angustia").

De especial interés son las técnicas con las que se manipula la atención del lector. Por una parte, el narrador llama la atención a la identidad de la mujer del relato ("Jamás mientras viva se me olvidará aquella mujer”), pero a la vez la oculta (“aquella desconocida que no existe"). Aunque el punto de vista que prevalece es el del sujeto, es el narrador del texto quien regula la información que llega al lector, además de que determina el momento en el relato en el que debe aparecer.

El segundo núcleo narrativo describe las acciones del sujeto que conducen al clímax, un giro inesperado con el que concluye el relato:

Pasaron dos minutos. Ustedes caminaban despacio conversando en voz baja. Levanté la mano y le hundí el puñal en el corazón. Entonces pasó algo cuyo recuerdo me horroriza... Aquella mujer era yo misma. En un arranque de celos salvajes acababa de matarme. El pesar de tu desesperación y la sensación inexplicable de verme muerta para siempre fueron tan violentos que me desperté sollozando.

Parecería que Borrero trabajara con dos medidas de tiempo que circulaban independientes y a un ritmo desigual: una de paso acelerado para el tiempo que fluye dentro del mundo del sujeto ("averigüé", "esperé” "sentí", “escuché”); otra de paso 
retardado, en donde el narrador retoma la historia ("pasaron dos minutos", "caminaban despacio"). Nótese que la lentitud con que se desplaza la pareja es una referencia tanto espacial como temporal, detalle que intensifica la ansiedad del sujeto, a quien le es imposible escuchar el diálogo de la pareja. A propósito de esa técnica narrativa, MariniPalmieri señala que Poe era maestro en el "arte de contar rompiendo nociones de tiempo, de lugar, dándole a éstas la tenue frontera que impone la imaginación y la memoria fértiles e indomables" (41). La manera con la que se describe el tiempo en función del espacio en este relato remite nuevamente a la influencia del escritor en Borrero.

En su análisis de Aurélia (1855) de Gerard de Nerval, relato de las visiones de un sujeto durante un episodio de locura, Tzvetan Todorov hace notar que la distancia que media entre el personaje y el narrador es el elemento que contribuye a la ambigüedad del texto (39). El lector del relato de Borrero percibe también que existe una distancia implícita entre el sujeto del sueño, quien vive en el pasado, y el narrador, quien trascribe sus acciones desde el presente. Esas dos perspectivas se entrecruzan durante la lectura: el narrador describe sus propias sensaciones (relato en primera persona), mientras relata las acciones de un sujeto que, al pertenecer al mundo de los sueños, aparece como una identidad independiente del narrador (desplazamiento implícito hacia la tercera persona).

Una de las características del microrrelato es que su desenlace plantea una ruptura con las expectativas del lector. En este caso, en donde las entidades (textuales y reales) se superponen, las expectativas del lector quedan burladas: el sujeto es a la vez víctima y homicida. El narratario, como personaje de la historia, no es capaz de percibir la duplicidad del sujeto ("tu desesperación"), ni de escapar de su angustia: el relato 
terminaba dejándolo atrapado en la historia, además de que su función como lector pasivo quedaba removida. $^{76}$

Aunque Borrero hablaba con frecuencia de su deseo de morir, nótese que la acción del sujeto del sueño no es un acto suicida, sino criminal. ${ }^{77}$ Aprovechando las circunstancias de aquel sueño como pre-texto temático, componía un relato cuyas estrategias narrativas delataban su función artística, así como también intimidatoria. Su modo de presentación demostraba la influencia del relato gótico psicológico en su narrativa, en donde lo insólito se presenta a partir del estado enajenado del sujeto, de un episodio de locura o de un sueño.

Acerca del relato fantástico moderno, Phillipps-López explica:

Modernidad y fantasía se solidarizan, y en esta medida y

contexto se consolidó significativamente en Hispanoamérica la narrativa fantástica. En cuanto en ella se expresa una disposición espiritual nacida de una vivencia conflictiva, ambigua, de la realidad, es posible definir la narrativa fantástica como modalidad estética genuinamente moderna" $(32,33)$.

Debido a los estados pesimistas y la incertidumbre de los tiempos, proliferaron los cuentos fantásticos durante el modernismo, como en "El sueño de Magda" (1883) de Gutiérrez Nájera, "La protesta de la Musa” (1881), de José Asunción Silva y "El amante de las torturas" (1893) de Casal. Microrrelatos dentro del género de lo fantástico, como

\footnotetext{
${ }^{76}$ Compárese este lector con el que años después encontramos en "Continuidad de los parques", de Cortázar. El lector queda atrapado en su propia lectura, cuando el escritor le obliga a participar en la historia.

${ }^{77}$ Léase, por ejemplo, la Carta 145, en la que habla del suicidio como respuesta al anuncio de Carlos Pío de marchar a la manigua.
} 
el del sueño de Borrero, también se cultivaron con mucho acierto durante el modernismo. Dos de ellos escritos al final de ese período literario (1922) son "Fantasmas" y "El pisapapel”, citado anteriormente, ambos del escritor cubano Alfonso Hernández-Catá.

Comparando los relatos de la Carta 120 del desfile fantasmal con el relato del sueño de la Carta 104 encontramos que, mientras la primera trata de los problemas del "Yo" (el temor a la soledad, el abandono), la segunda trata de los problemas con el "Otro" (el tema de los celos y la traición). En cuanto al modo de presentación, el marco epistolar venía a complicar la dinámica del paradigma emisor-mensaje-receptor, ya que el autor implícito, la escritora, tenía un propósito ulterior para el lector real: influir en su voluntad por medio de la escritura. Lo fantástico aparecía en varios niveles interpretativos, en donde lo posible y lo imposible interactuaban peligrosamente. Sus estrategias literarias, ensayadas en aquel único lector, respondían a un afán de posesión absoluta: "Hoy te poseo" (EII 93). Esa intención, junto con el miedo al abandono, era parte de literatura del deseo, de la pérdida, de la ausencia y del desorden emocional del artista de fin de siglo (Phillipps-López 46).

Es cierto que Juana al final de la Carta 104 llama la atención a la naturaleza onírica de su relato: “iQué sueño tan extraño. Yo misma asesinándome y contemplando y mi propio cadáver". Sin embargo, esto aparecía nuevamente como negación del enunciado, ya que con una salvedad, si se quiere extra-literaria, hacía de la historia un reflejo de la realidad: "Después he pensado mucho en mi pesadilla. Me parece descubrir en ella un símbolo oculto y misterioso". La duda de lo fantástico, que se evapora a medida que el lector descubre la naturaleza del relato (Todorov 41), no debía ni podía existir aquí, porque el lector sabía de antemano que se trataba de un sueño contado desde 
la realidad. No obstante, los textos de Borrero le impactaban de manera inquietante: el suspenso trascendía la lectura, y lo fantástico se transformaba en amenaza premonitoria.

Otros relatos del Epistolario vienen a confirmar la capacidad de Borrero para la narrativa. Con la partida al exilio en Cayo Hueso, el sábado 18 de enero de 1896, comienza una nueva y última etapa para la escritora cubana: está a sólo dos meses de su muerte. Carlos Pío le promete seguirla al exilio, así como lo hizo su hermano, Federico para reunirse con Elena, hermana de Juana. Ella escribe: "La promesa que me haces de seguirme a donde quiera que me lleven, es lo único (óyelo bien) lo único que me consuela en mi desesperación" ( $E$ II 253). Sin embargo, por razones que el tiempo no ha podido justificar, él no va a su encuentro. Siete días antes de la partida, el 11 de enero de 1896, y bajo el temor que esto ocurriera, Juana escribe: "Jamás el lenguaje ha sido más indócil $[\ldots]$. De un modo u otro la Patria ¿no es una rival como otra cualquiera? Y rival dichosa porque me sacrificas a ella!” Esta carta, la 198, la escribía en su totalidad con sangre de las venas de su brazo izquierdo, según ella misma describe.

No obstante, el exilio despierta en Borrero el deseo de describir su nuevo entorno, lo que representa un paréntesis artístico que se alimenta de la esperanza del reencuentro. Dos de sus relatos eran tal vez cuentos alegóricos, como el que aparece en la Carta 206, la historia de una novicia, "Sarha", de "ojos verde-claro fosforecen febriles y lánguidos entre el cerco violáceo de las ojeras dilatadas e intensas. La batista nevada de sus tocas la circunda de un nimbo cándido que es el mejor marco de su rostro de enferma”. Su novio la abandonaba para casarse con su madre: "Ella no ha perdonado aún a su madre [...] a su amado sí. [...] Su historia es triste verdad? y quizás no te sea del todo extraña... ”. Era 
posible que viera reflejado en esta historia su drama sentimental: ella, la novicia abandonada por su novio, y la madre que la traicionaba, la Patria, "la rival".

Cuatro días después, la historia de la novicia reaparecía con variaciones, esta vez con un sabor costumbrista sobre la sociedad del cayo: “LLas mujeres? Cursis hasta el refinamiento. Sólo hay una elegante, una dama que parece una duquesa. Espléndida mujer con quien nadie se trata. [...]. Yo la he visto varias veces en la calle Duval a pie o en coche $[\ldots]$. Es la nota elegante de esta sociedad mediocre". Aquella mujer se llamaba "Sara", nombre que describe como "el roce de un pliegue de moaré blanco". Su amante estaba comprometido, así como Carlos Pío estaba comprometido con la causa de Cuba. Días después Juana le confiesa: “esa historia es pura fantasía mía. Ni yo la he visto, ni ella está aquí, ni se ha movido de la Habana" (EII 340). Sin embargo, para ambos relatos (“Sarha" y "Sara"), parecía corresponder un sentido alegórico de trasfondo nihilista, un dilema sentimental que no pudo resolver en vida.

Juana Borrero muere a la edad de dieciocho años, el 9 de marzo de 1896, tres meses después de haber salido de Cuba, a consecuencia de fiebre tifoidea según consta en el registro de defunciones de Cayo Hueso. Esteban Borrero, padre de Juana, habla de su dolor a Carlos Pío, en una carta en donde nos parece escuchar ecos martianos: "Nuestra propia alma, como espantada ante la magnitud de su infortunio, cierra ante él, apenas entrevisto, los ojos y huye con la visión incompleta del dolor a devorar aquella porción de él que le es dado abarcar sin desfallecer. Me siento morir: no concibo por qué proceso espiritual ha de llegar a mí el consuelo [...]” (en Morán 223, 224). Cuatro años después, su dolor apenas había cambiado, y hasta escribiéndole a un amigo, Nicolás Heredia, continuaba en diálogo con la hija muerta: "Por dilatada que llegue a ser mi vida, moriré 
antes de que pueda consolarme de tu muerte" (en Morán, La pasión 227). Incapaz de superar aquel sufrimiento, e insatisfecho con la intervención norteamericana en Cuba, Esteban Borrero se suicida el 29 de marzo de 1906.

Seis días después de la muerte de Juana, Carlos Pío escribía en El Fígaro, del 15 de marzo del 1896: "siento el vértigo que producen las caídas en los precipicios y que se abre en mi alma la flor embalsamada de la fe religiosa, no sé si blanca o negra, porque las sombras de mi espíritu me impiden percibir el matiz de su corola" (en Morán 253-255). Perder a Juana representó la pérdida de la compañera sentimental, y de ella decía en el mismo artículo: “yo, confidente de esos desvaríos ansiosos, la escuchaba, la escuchaba, sugestionado por la magia fascinadora de su verbo!”. Perdía también la compañera epistolar, aquella que estimulaba en él el placer de la lectura íntima. Sin embargo, ese embrujo le provocó una dependencia emocional sustentada por la intimidación, así como ella le exige en la carta escrita con sangre: "te exigí la consagración absoluta" (EII 257). Su deseo de posesión terminó contaminando el lenguaje de sus cartas, como aparece en el siguiente pasaje: "Quisiera matarte sin quitarte la vida, aniquilarte sin perderte" (EII 194). Sobre estas manifestaciones de amor enfermizo, Francisco Morán explica: "El placer no consiste en destruir al objeto del deseo, sino en destruirlo infinitamente. No se trata de aniquilarlo para siempre, sino incesantemente" (xix). Tales expresiones terminaron por impresionar irracionalmente la sensibilidad de su interlocutor.

Carlos Pío, cómplice y sustentador de aquella enfermedad de poder, respondía a los delirios de Juana con similar sensualidad decadente: "te asesinaría calculada y fríamente sin la más leve sombra de un remordimiento" (en la Carta 152). Este era un caso raro y excepcional en la literatura cubana. Eran parte del grupo de los artistas que se 
auto-denominaron "raros", y de quienes Vitier explica: "su enfermiza y desquiciada subjetividad es la única vía por donde puede llegarnos a expresión, el testimonio de realidad que sin embargo nos tocan muy de cerca" (Lo cubano 225). Persuadido o intimidado, Carlos Pío desarrolló una co-dependencia emocional hacia aquel discurso enfermizo. Producto de una de las épocas más convulsas de la historia y de la literatura, aparecieron en Cuba estas sensibilidades que dejaron su marca en el arte.

Se cree (nunca se ha determinado con exactitud) que Carlos Pío Urhbach fallece en la manigua a la edad de veinticinco años, un año después de la muerte de Juana, el 24 de diciembre de 1897. Se encontraron algunas cartas de Borrero y un mechón de su cabello cosidos al interior de su chaqueta. Con la muerte de estos dos jóvenes poetas, morían también los mejores discípulos del modernismo cubano a lo Casal. La guerra afectaba el período de 1895 a 1913 cuando, según Vitier, el panorama literario se presentaba "vacilante, confuso y en términos generales, mediocre" (Lo cubano 230). Tal vez sea por esa carencia que el Epistolario de Borrero se nos hace tanto más esencial en la historia del arte y de la cultura cubana.

Las cartas de Borrero son un kaleidoscopio literario, que con la libertad de la escritura íntima se presenta con una plenitud artística difícilmente lograda en otros medios. La escritora tomaba de los temas románticos los más sugestivos: la contemplación del paisaje, la subjetividad, el gusto por lo fantástico. Partía de la influencia de la poesía de Heinrich Heine (1797-1856), poeta alemán que con sus osadas frases propicia el fin del romanticismo, y luego de Manuel Gutiérrez Nájera (1859-1895), 
pionero de la estética modernista hispanoamericana. ${ }^{78}$ Su mayor admiración la sentía por Julián de Casal, el Divino (EI 248), y queda en la literatura cubana como una de sus mejores discípulas.

Sin embargo, ni la naturaleza ni el amor fueron para Casal motivos de inspiración, como sí lo fueron para Borrero. Así aparecía en los poemas del poeta, "Mis amores" y "En el campo". En Borrero, en cambio, existía la lucha entre el sentimiento y el esteticismo parnasiano que observa Iván Schulman:

los versos que resultan encierran una tensión, por un lado, entre la busca de la distancia psicológica, la frialdad, la línea esculpida o el espacio coloreado, y, por otro, la necesidad o el deseo de dar rienda suelta a los sentimientos íntimos, cuya incorporación discursiva vedó la teoría parnasiana. Y en los versos de Borrero este doble venero - conflictivo también se evidencia, triunfando la mayoría de las veces, el filón de la introspección [...] (El proyecto, 147$)$.

Tal vez uno de los legados más preciados de su epistolario son las páginas que Borrero intercambia sobre crítica literaria. Es allí en donde parece que ese conflicto entre el sentimiento y la estética parnasiana ya quedaba resuelto en ella. Su clarividencia sobre las disciplinas del arte y sus conceptos alcanzaban una fuerza innovadora que a veces se manifestaba en posiciones iconoclastas.

\footnotetext{
${ }^{78}$ Por ejemplo, existe una correspondencia directa en el poema "Vorrei morire" y "Para entonces" del poeta mexicano.
} 
En pleno apogeo del modernismo de la literatura cubana, Borrero discernió que existía una barrera conceptual entre lo auténtico, producto de la introspección, y lo vacuo, excesos que empañaron algunas composiciones modernistas. Su concepto de arte se resumía al explicar, "Sufrir! He aquí el secreto del Arte" (EII 134). Su disidencia se inspiraba en las raíces de su propia esencia, así como ella misma explica: "Soy la mezcla más compleja de creyente y pesimista, de fatalista y de optimista" (EI 201). Esa actitud contestataria está mejor explicada en la carta del sábado 28 de septiembre de 1895:

Cuando tú y yo tengamos que luchar abiertamente con un medio antagónico $[\ldots]$ ¿seguirás evocando los biombos, los tapices, las porcelanas. [...] ¿Será posible que en tus rimas no se traduzca el estado de tu alma y que una pluma de cisne, o un pliegue de seda, o las facetas de un zafiro y una nube de encaje te absorban y te consuelen?[...] (EI 423).

Su actitud crítica no iba en contra de los elementos más representativos de la estética modernista, ya que éstos habían contribuido a la emancipación de los desbordes emocionales del romanticismo, así como del lenguaje del realismo y del naturalismo. Más bien se pronunciaba en contra del arte que pretendía reflejar emociones a través de fórmulas vacías, cuando éstas no alcanzaban a representar genuinamente la realidad del artista.

En relación a lo anterior Iván Schulman plantea: “ Lo que quisiéramos más bien es señalar cómo en y qué medida su discurso poético se inserta en el del modernismo hispanoamericano, buscando en su arte no los nexos entre vida y verso, que son muchos y significativos, sino la voz del sujeto fin de siècle, la del artista atormentado y aislado, 
víctima de las incertidumbres del mundo moderno, [...]" (El proyecto 144). A la angustia del sujeto del fin de siglo habría que agregar la consternación del artista cubano, quien como Borrero, se encontraba en medio de una guerra de independencia tardía, sumido en la consternación nacional y familiar. Su discurso poético, no el de su obra pública sino el íntimo del Epistolario, se insertaba al arte finisecular con una temática que no podía ignorar la realidad inmediata. Es así que su actitud iconoclasta en lo literario se extendió hasta invadir el sentimiento patrio, lo que motivó que al final de su vida adoptara un discurso nacional impresentable y no compatible con la historia oficial.

Es cierto que entre los poemas de Borrero figura la lírica patriótica, como en “iEsperad!”, dedicado a Diego Vicente Tejera. Sin embargo, su actitud disidente se radicaliza a medida que se enfrenta en solitario a su propio destino. Ante el deseo de Carlos Pío de marchar a la manigua, como tantos otros lo habían hecho, redacta la Carta 145 en la que dice: "Yo no tengo más patria que tu alma. [...] Eres mi patria, mi religión, mi arte, mi universo, mi alma [...]" ${ }^{79}$ A partir de entonces comienzan a aparecer en las cartas frases de verdadero espanto: "Qué mayor dicha para mí que morir sintiéndote mío? Ah pero no iré sola! Aún tendré fuerzas en mi agonía para ahogarte en mis brazos y arrastrarte conmigo hasta mi helado lecho!" (EII 320).

Con la escritura del Epistolario, Borrero lograba su propósito inicial: la posesión absoluta de la voluntad de su interlocutor. Para ello intentaba borrar su memoria sentimental y colmar su presente, así como él le escribía: “Anoche releí varias cartas tuyas $[\ldots]$ mis impresiones de entonces permanecen intactas en mi recuerdo" (EII 366). Lograba además que Carlos Pío la visualizara envuelta en el misterio y la ambigüedad

\footnotetext{
${ }^{79}$ Véanse también las cartas 94, 155, 187, 201, entre otras.
} 
que generaban su poder de intimidación. Entre sus apuntes aparecía esa inquietud: ¿¿Eres hada o diosa? ¿Madona o elegida? ¿Sueño o realidad?” (en Morán 252). Medio siglo después, mientras Vitier trabajaba en la transcripción de las cartas, cuenta que Mercedes, hermana de Juana y albacea de sus misivas, se las entregaba en sucesivos sábados, sacándolas “de misteriosos cofrecillos con un extraño aroma astral de amor y de muerte" (7). Una evidente perplejidad embargaba también al crítico cubano, quien temía profanar aquella intimidad. ${ }^{80}$ Hoy, una relectura en retrospectiva confirma la relevancia de una evaluación antológica y crítica de las cartas de Juana Borrero. Sus ejes temáticos, Arte, Amor y Muerte, fusionados a la estética dominante, son un boceto de lo que pudo haber sido su obra literaria.

Ivan Schulman señala que los modernistas, intuyendo la necesidad de "un reajuste ontológico, intentaron construir universos alternativos, fundamentalmente esencialistas" (El proyecto 21). Juana se presenta a ese reajuste ontológico con la propuesta de un antimundo para sobrellevar la incertidumbre de aquellos tiempos. Martí describía así su propia perplejidad, "Hijo: Espantado de todo, me refugio en ti" (Ismaelillo 5). Y también Borrero, “¿Qué sería de mí a veces si no tuviera un mundo oculto donde refugiarme cuando la realidad me hiere despiadada?” (EI 147). Era la queja que trascendía la tragedia cubana en Martí, así como la sentimental en Borrero.

Considerada una romántica tardía dentro de las huellas de Casal, Borrero aprendió del parnasianismo a trabajar con imágenes poética muy plásticas y con recursos multi-

32 Obsérvese la anotación de Vitier en el prólogo del epistolario: "no sabemos cuánto, de la carta específica, del verdadero sentido, de la energía amorosa, se pierde en el traslado de medio, como el paisaje trémulo al entrar en la placa fotográfica; [...] cuando leemos, [...] «He querido que mi letra sea solamente tuya como es únicamente tuyo mi corazón», comprendemos que esa imposibilidad es justa" (8). Ver notas a la Carta 10, en donde Vitier encuentra el efecto de las lágrimas sobre la tinta, o en la 84, carta escrita con sangre. 
sensoriales. Captó del símbolo su poder en la interiorización del paisaje, y se inscribe como poeta quien, tal vez entre Zenea y Martí, percibe del paisaje las conexiones universales que la reconcilian con la creación. Del arte decadentista asimiló la apropiación del ornamento de una espiritualidad ambigua. Por último, se apropió de la herencia romántica de lo fantástico y la adaptó al lenguaje modernista en un sincretismo de estilos. Más importante aún, dejó una huella inédita en la prosa femenina, para inscribirse en el lenguaje de la modernidad que anunciaba el advenimiento de las vanguardias. 


\section{Conclusión.}

Las cartas de amor de Gertrudis Gómez de Avellaneda y de Juana Borrero son un cuerpo de escritura íntima que por su composición y contenido marcan un hito de ruptura y continuidad en la tradición epistolar femenina. En un momento histórico cuando la mujer se integra a la vida social y literaria, sus cartas representan la consolidación del sujeto marginado, posición que asume trastornando el orden de jerarquías del paradigma de la carta amorosa. Esta innovación del género es producto de técnicas de escritura que imparten dimensiones estéticas a documentos a los que por definición no se les atribuye una intención literaria. En los capítulos anteriores proponíamos un método de análisis, enfocado en estudiar en estas cartas la intención, propósito, composición espacial y temporal, perspectiva y función de las entidades epistolares, así como las señales textuales que distinguen la forma epistolar de la literaria. Con esa herramienta de análisis abordamos este tema enfocándonos en las estrategias tras el propósito de esta escritura, a saber, la persuasión como ejercicio del poder.

Argumentábamos que Avellaneda reclamó el derecho a definirse y a expresarse desde una perspectiva crítica sobre el destino de la mujer, la sociedad y el arte. Su obra, según Susan Kirkpatrick, propició un cambio en la opinión pública sobre la participación de la mujer en la vida social y literaria: "gracias a Gómez de Avellaneda y a la hermandad lírica", es decir, al grupo de escritoras románticas de la mitad del siglo XIX (Las Románticas 228). Sin embargo, aunque la naturaleza íntima de su epistolario limita su capacidad de influencia, esta práctica le proporcionó la oportunidad de desarrollar y madurar las ideas que luego se reflejaron en su vida y en su obra pública. Hoy, que el conflicto de la mujer decimonónica nos parece resuelto y distante, sus cartas aún nos 
seducen por su carácter intelectual y natural elegancia. El arte epistolar amoroso en Avellaneda es una tarea de simetría estructural y organización estética.

Por otra parte, el epistolario amoroso de Borrero se escribió durante el período literario que Vitier describe como aquel "apagado tránsito de nuestro segundo romanticismo al renacer modernista" (Lo cubano 213). No obstante, su extenso epistolario es una muestra de lo que pudo haber sido su obra literaria en aquel tiempo de reajustes estilísticos y ontológicos. Aunque dedicada a la escritura secreta, Borrero no era otra "demente del desván", es decir, no era la mujer de la literatura decimonónica, secuestrada por los valores ajenos (Gilbert \& Gubar 79). Juana se confinó a sí misma en un acto paradójicamente emancipador para dedicarse a la creación artística. Con un bovarismo espiritualizado que partía de la literatura romántica, Borrero es creadora de existencias fantásticas, e intentaba crear en la realidad lo que la literatura gótica le inspiraba en la ficción. Ella explica: "Soñaba con un hombre imposible, con un hombre casto. Acaricié mi creación con todo el amor de un artista a su obra. Aquel amado imaginario ocupaba por completo mi imaginación y lo perfeccionaba..." (EII 267). Este empeño irracional la llevó a la creación de un entorno de intimidación, un mundo en donde el arte sustentaba la irrealidad.

Sobre la creación de realidades alternas que en los modernistas se interpreta como escapismo, Vitier explica: “ocultarse no es huir, sino replantear la batalla en otro terreno [...] dar un paso al frente en la batalla secreta, oculta, de la expresión" (Lo cubano 216, 217). Borrero, a fuerza de escribir día a día, construyó un mundo en donde el arte colmaba toda expectativa imaginable. Esa era su batalla individual, librada en el terreno del amor y del arte hacia la conquista de la perfección como modelo de vida. Vitier 
explica en el prólogo a las cartas en la medida en la que su epistolario es un legado inestimable de material didáctico: "Los estudiosos de nuestras letras encontrarán en estas cartas una enorme cantera para conocer íntimamente lo que fue el primer modernismo entre nosotros [...]. Los estudiosos del alma humana, tendrán a su disposición un documento psicológico y espiritual de primera magnitud" (31). Además de estos campos de interés, el estudio de los epistolarios aquí propuestos contribuye a estudios que contemplan otras aproximaciones.

La crítica feminista, enfocada en interpretar la escritura de mujer, tiene en su agenda el ir al rescate de la voz silenciada por la auto-censura que se impuso la escritora a sí misma. Iris Zavala explica los beneficios de ese empeño: "Nos induce a abordar el mundo del silencio, el de la palabra ambivalente, el mundo de los signos, y a sospechar de las apelaciones de autoridad, de verdades, de nociones de identidad personal trascendente, de los mitos [...] (Breve historia, I 76). Sin embargo, la escritura epistolar de Borrero y Avellaneda es la palabra atrevida de la mujer emancipada, emitida con la autoridad que ellas se apropian dentro de las relaciones de poder. Pero aquella era una voz articulada en un medio subyacente, un mundo prohibido a la mirada ajena, aunque parte integral del sentir y el pensar del sujeto femenino en su función creadora.

En su libro Mujer, modernismo y vanguardia en España (1898-1931), Susan Kirkpatrick explica que los comportamientos y las expresiones extraliterarias, ya sean las memorias, entrevistas, narrativa, prácticas y comportamientos sociales eran "indicios reveladores de cómo se posesionaban (y eran posicionadas) las mujeres escritoras y artistas dentro del contexto social y discursivo concreto y de cómo percibieron así distintos significados en el desarrollo de la modernidad española" (16). Desde nuestra 
perspectiva, agregaríamos que estas cartas (documentos invisibles al estudio de los comportamientos sociales que propone Kirkpatrick) contribuyeron con un aporte modesto y secreto a las ideas que conformaron las actitudes femeninas.

Pero además de lo anterior, como tercer lector (el escritor es siempre el primero) cuestionábamos la validez y la utilidad de una aproximación literaria a las cartas de amor de Avellaneda y Borrero. Primero las leímos con la mirada no comprometida del lector moderno: la carta era un texto ajeno, profanado por nuestra lectura, documento obsoleto que no lograba superar su valor biográfico, y tal vez tampoco el social ni el cultural. En una segunda lectura, en donde aplicamos el mismo rigor de análisis que a los textos literarios, descubríamos lo que en ellas aún nos conmueve, es decir, las características formales que según Guillén convierten una carta en un texto literario (“On the Edge"17). Tal vez esa era su característica más relevante, es decir, su capacidad de rebasar el carácter anecdótico y trascender. Acerca de esta idea, Fernando Pessoa explica: "El artista [...] debe procurar alzarse más allá de su época” (Sobre literatura 280). De ahí lo que caracteriza a una obra literaria: la capacidad del artista de conmover con su lenguaje al lector de todos los tiempos.

En el presente ensayo nos habíamos enfocado en el análisis del lenguaje del poder, pero en el proceso de ese intento descubrimos también el poder intemporal del lenguaje. La sensibilidad estética de estas cartas trasciende su propia estrechez anecdótica, es el arte como un acto de interpretación individual a la temática universal. Sólo el arte superior tiene el poder de darle a la realidad de cada lector un aspecto superior a la realidad misma. El arte superior tiende a elevarnos, y a hacernos imaginar de manera diferente lo que ya conocíamos (Wellek y Warren 41). 
Sin embargo, décadas después de su publicación, la naturaleza literaria de los epistolarios de Borrero y Avellaneda aún se señala con imprecisión. Es cierto que en el prólogo de las cartas de Avellaneda, Selimov explica: "La autora adapta un lenguaje literario a su situación personal, es decir, literaturiza [...]” (26). Pero preguntábamos, ¿en qué forma se "literaturiza”?, ¿Por medio de qué estrategias? ¿Siguiendo qué modelos e innovando cuáles? ¿Dónde su aporte a la escritura epistolar femenina? Vitier, por su parte, en el prólogo del epistolario de Borrero advierte: "no se trata aquí de una obra literaria, sino del diario de un alma poseída por el filtro de la pasión" (11). Concordamos con él en que el epistolario, como lectura global, no es una obra literaria, sino un conjunto de mensajes amorosos. No obstante, ponderamos el hecho que sintió la necesidad de hacer aquella salvedad, porque tal vez anticipara la inquietud de más de un lector. Es por ello que nos dimos a la tarea de su investigación.

La relación atracción/rechazo que genera la carta en general traen a la mesa de investigación otras preguntas en cuanto a la validez de su estudio. Bastons i Vivanco interroga en su artículo, "Polisemantismo y polimorfismo de la carta en su uso literario":

¿por qué queda tan marginado de los estudios literarios? ¿por qué no han aparecido antología de epistolarios famosos? ¿por qué no se trabaja en las clases de literatura, sean del nivel que sean - primaria, secundaria, universitaria - con textos epistolares? Son interrogantes que planteamos y que hoy por hoy no encuentran respuesta en los planes de estudio (Bastons I Vivanco 238). 
Planteábamos al inicio de este análisis que la respuesta a estas preguntas requería la búsqueda formal que planteaba Guillén. Es por eso que creímos prudente limitar el foco de la búsqueda y concentrarnos en identificar unas cuantas estrategias de escritura con las que estas escritoras abordaban la tarea de la persuasión. Así descubrimos que la carta amorosa de Avellaneda es una fusión del discurso neoclásico con la pasión romántica, organizada en un diseño de simetría y equilibrio epistolar. Encontramos además que la carta en Borrero es la propuesta intuitiva de un arte en transición conceptual y estética hacia el modernismo.

Una definición de lo que es una obra de arte amplía la relevancia de un análisis literario de las cartas en cuestión. Fernando Pessoa explica: "El arte inferior causa placer porque distrae, [...]; el arte superior causa placer porque libera, libertad porque libera de la propia vida (Pessoa 286). Cepeda atesoró las cartas de Tula y las hizo trascender a su vida misma, intuyó que éstas podrían apelar a un público más amplio. Carlos Pío creyó en el poder sustentador de las cartas de Juana, y se hizo acompañar por ellas hasta la muerte. Pero a nosotros, como lectores de cartas que se escribieron hace más de un siglo, ¿por qué aún nos seduce su lectura y, según el pensamiento de Pessoa, por qué aun nos libera su lectura?

Leyendo las cartas de estas escritoras, en donde el genio no escatima hacerse brillar en un género menor, reflexionamos en el interlocutor como co-partícipe de estos proyectos, y nos sobrecoge la idea de la posibilidad de su inexistencia, o de la existencia de algún otro que no hubiera estado a la altura de aquel concepto. Léanse, por ejemplo, las cartas de Delmira Agustini a su esposo, y luego compárensen con las que le inspirara aquel único e irremplazable lector, Manuel Ugarte: "Perdónele a mi alma si lo quiere más 
que en la púrpura hiriente de los triunfadores, en el luto adorable de los injustamente vencidos" (en Silva 50). No es cualquier interlocutor el que inspira una obra de la magnitud de los epistolarios aquí estudiados. Con respecto a la importancia del lector en toda tarea de escritura, Barthes apunta: "Es preciso que yo busque a ese lector (que lo "rastree") sin saber dónde está. Se crea entonces un espacio de goce. No es la "persona" del otro lo que necesito, es el espacio: la posibilidad de una dialéctica del deseo, de una imprevisión del goce; que [...] haya juego todavía" (12). De ahí lo que representa el interlocutor en esta escritura: la posibilidad del espacio. En toda carta en la que hallamos algún relieve o calidad estilística tropezamos con esa figura cómplice, generadora de espacios y de posibilidades creativas, el pre-texto de escritura.

Para que la carta privada de Borrero y Avellaneda supere hoy la prueba del análisis crítico, debe apelar al interés y al gusto del lector moderno. Sería suficiente para nosotros creer que nuestro interés, como advierte Barthes "existe: es la escritura", cuyos principios no se reducen a ningún otro tratado sino a la escritura misma (14). Guillén había preguntado en cuanto a la carta: "How often does literature affect non-literary communication? [...] The self-controlled liberation from the norms of literary language has had unusual consequences" ("On the Edge" 21). Estas escritoras alcanzaron la plenitud artística porque en ellas el lenguaje poético era una constante del espíritu. A nosotros, como lectores modernos, su escritura nos acerca a esos mundos desiertos de lectores para descubrir el arte más allá de lo que parecía evidente.

Recuperar la voz secreta de las cartas de Gertrudis Gómez de Avellaneda y de Juana Borrero significa ampliar la percepción que tenemos de ellas en su función de autor. Foucault señala: "Finally, the author is a particular source of expression that, in 
more or less completed forms, is manifested equally well, and with similar validity, in works, sketches, letters, fragments, and so on" (en Dreyfus and Rainbow 983). Reconocerles a estas escritoras la función del autor (pensemos no sólo de cartas, sino también de manifestaciones de otras disciplinas del arte, como la pintura en Borrero) modifica la recepción que sus nombres representan. Con la lectura de su epistolario, por ejemplo, el nombre de Gómez de Avellaneda, la enérgica escritora cubana, acogería también las estrategias de escritura de la mujer enamorada pero no correspondida. El de Borrero haría lugar para que la percepción de la adolescente incomprendida diera cabida a la de la artista realizada.

Carles Bastons i Vivanco, citando al escritor catalán, Albert Manent, subraya el valor tangencial de los epistolarios en general: reflejan "la madurez una cultura" (en Baston I Vivanco 236). En el caso que nos ocupa, diríamos que no sólo la cultura ya hecha y madura, la que nos es dada para identificarnos con ella, sino de aquella en formación, en tránsito y ocupada en reclutar las voces individuales que conformarían la esencia. Las cartas de Avellaneda y de Borrero nos hacen conscientes de la madurez intelectual y artística de la Cuba del siglo XIX. Pero cuando Juana escribe, "no tengo más patria que tú", se inscribe como parte de un proceso gradual y secreto, que de manera imperceptible fraguó también la cultura.

Pero existen otras cartas cuyos escritores no reconocemos, porque sus voces quedaron atrapadas en una historia paralela a la que aprendimos, forjadores anónimos de un proceso de aculturación. Esas fueron las cartas de los primeros hombres y mujeres que emigraron a Cuba, y de las subsecuentes olas de inmigrantes de todos lo tiempos que dieron forma a lo que hoy es América. Sus cartas, por ejemplo, dejaban frases de 
soledad: "con impaciencia te aguardo a cada momento" (en Pérez Murillo 35). Aquella voz epistolar quedó silenciada por la voz colectiva, y ni la historia ni la literatura creyó prudente rescatar.

Hacemos nuestra la inquietud de Katharine Ann Jensen: "we can only wonder how many women, throughout history, wrote (love) letters and how many of those letters will always be lost" (125). Ivan Schulman ha hecho una llamada para reunir aquellos textos que quedaron dispersos en periódicos y revistas (El proyecto 179). A esto añadiríamos reunir también aquellos textos que quedaron dispersos entre epistolarios y cartas: poemas, cuentos, crítica literaria, narrativa costumbrista, aforismos. Hasta hoy se ha realizado un rescate parcial de la voz femenina. Queda aún pendiente el rescate, ya no de la voz de la mujer que a sí misma se margina en los silencios de la auto-censura, sino de la voz de la artista articulada en un medio que hoy sufre una marginalización más lamentable, la marginalización de la voz epistolar.

No obstante, a la crítica moderna le han salido al paso estudios sobre las nuevas formas de comunicación escrita. El anonimato que permiten los nuevos medios de comunicación, como expresión moderna y renovada de la escritura epistolar, ha reabierto la posibilidad del arte. La crítica literaria ha acogido esos textos como espejo de la vida actual, y encontramos ya trabajos serios como en El correo electrónico: el nacimiento de un nuevo género (2006), y el artículo "El correo electrónico como nuevo género epistolar en la literatura actual" (2004). Es posible que se publiquen también "epistolarios" de esas nuevas manifestaciones, entonces no sería extraño que nuevamente nos planteáramos el tema de la posible literariedad de la escritura cibernética. 
Reabrimos aquí el capítulo sobre el estudio de la carta que se había cerrado durante el neoclasicismo con el advenimiento de la novela. Queda aún pendiente la relectura de otros muchos epistolarios y de cartas individuales, documentos cuyos valores artísticos superan las limitaciones genéricas. Tal vez así la carta reivindique su valor atemporal, y recupere en concepto y apreciación el lugar privilegiado que tenía en la literatura clásica. 


\section{BIBLIOGRAFÍA}

Abaelardi, Petri y Heloissae. Cartas de Abelardo y Eloísa. Madrid: Alianza, 2007.

Acín, Ramón. "De la invisibilidad a la presencia". Cuadernos hispanoamericanos 699. (2008): 83-102.

Aínsa, Fernando. "La nueva novela histórica latinoamericana". Plural 240 (1991): 82-5.

Agustini, Delmira. Poesías completas. Ed. Magdalena García Pinto. 2nd ed. Madrid: Cátedra, 2000.

--- Poesías completas. Ed. Manuel Alvar. Barcelona: Labor, 1971.

Albin, María C. Género, poesía y esfera pública. Gertrudis Gómez de Avellaneda y la tradición romántica. Madrid: Trotta, 2002.

--- "El costumbrismo feminista de Gertrudis Gómez de Avellaneda". Anales de Literatura Hispanoamericana 36 (2007): 159-170.

Alcoforado, Mariana, Cartas de amor de la monja portuguesa. Trans. Almudena Alfaro. Barcelona: Obelisco, 2001.

Álzaga, Florinda. La Avellaneda: intensidad y vanguardia. Miami: Universal, 1997.

--- La Avellaneda: diccionario de pensamientos y vivencias. Miami: Universal, 2003.

--- $\quad$ Las ansias de infinito en la Avellaneda. Miami: Universal, 1979.

Anónimo. El lazarillo de Tormes. Barcelona: Actual, 2000.

Aragón, Uva. Alfonso Hernández-Catá. Un escritor cubano, salmantino y Universal. Salamanca: U Pontificia, 1996.

Arriaga Flórez, Mercedes. "Epistolarios en Italia: un punto de vista teórico sobre un género femenino". U de Sevilla.

http://www.escritorasyescrituras.com/cv/epistolarios.doc.

--- "Pido la palabra para amar: Gertrudis Gómez de Avellaneda". Sevilla U. http://www.escritorasyescrituras.com/cv/palabra.doc.

--- "Retórica de la escritura femenina". La retórica en el ámbito de las Humanidades: Seminario 2002-2003. U de Jaén (2003): 23-30. 
Arrufat, Antón. "Prólogo". Dos mujeres. Por Gertrudis Gómez de Avellaneda. La Habana: Letras Cubanas, 2000.

--- “Páginas tras La Avellaneda”. Opus Habana. No. 3, Vol. VI (2002): 4-15.

Ayala, María de los Ángeles. "Dos mujeres. Novela reivindicativa de Gertrudis Gómez de Avellaneda". http://cvc.cervantes.es/obref/aih/pdf/12/aih_12_4_012.pdf.

Bakhtin, M.M. The Dialogic imagination. Four Essays by M.M. Bakhtin. U of Texas Press. Austin.

--- $\quad$ Problemas de la poética de Dovstoievski. http://www.scribd.com/.../d/55933546.

Barthes, Roland. El placer del texto y lección inaugural. Buenos Aires: Siglo XXI, 2003.

Bastons i Vivanco, Carles. "Polisemantismo y polimorfismo de la carta en su uso literario". Sociedad Española de Literatura General y Comparada 10 (1996): 233-238.

Baudelaire, Charles. El spleen de París. Mararita Michelena (trad.). Buenos Aires: Losada, 2005.

--- $\quad$ The Flowers of Evil \& Paris Spleen. New York: Dovers, 2010.

Beebee, Thomas O. Epistolary Fiction in Europe. Cambridge UP, 1999.

Beltrán Almería, L. "Las estéticas de los géneros epistolares". Anuario de la Sociedad Española de Literatura General y Comparada 10 (1996): 239-246.

Benardo, Margot L. Crisol de amantes. El billete amoroso del Siglo de Oro. Madrid: Fundamentos, 2001.

Benstock, Shari, ed. The Private Self. Theory and Practice of Women's Autobiographical Writings. North Carolina: U of North Carolina P, 1988.

--- Women of the Left Bank. Paris, 1900-1940. Austin: U of Texas P, 1986.

Bertoni, María. “Agonía del género epistolar”. Espectadores. http://espectadores. worldpress.com/2007/06/09/agonia del genero epistolar/htm.

Biblioteca de Autores Cubanos, Obras de José de la Luz y Caballero. Vol VII. La Habana: Universidad de La Habana, 1949. 
Biblioteca Virtual Miguel de Cervantes: Diccionario de la literatura cubana.

Biografías y Vidas. Mujeres andaluzas. Biografías. $\mathrm{http} / / / \mathrm{www}$. andalucia.cc/viva/mujer/htm.

Boccaccio, Giovanni. El Decamerón. Madrid: ALBA, 2003.

Booth, Wayne C. The Rhetoric of Fiction. $2^{\text {nd }}$ ed. Chicago: U of Chicago P, 1983.

Böhl de Faber, Cecilia, «Fernán Caballero». “Carta a Mr. Federic Cuthbert. 1836. Caballé, 242-246.

Borges, Jorge Luis, Adolfo Bioy Casares y Silvina Ocampo. Antología de la literatura fantástica. Buenos Aires: Ed. Sudamericana, 1998.

Borrero, Juana. Epistolario I. La Habana: Biblioteca de autores cubanos. Academia de Ciencias de Cuba, 1966.

--- Epistolario II. La Habana: Biblioteca de autores cubanos. Academia de Ciencias de Cuba, 1967.

--- Poemas. Barcelona: Linkgua, 2007.

Bourneuf, Roland y Real Ouellet. La novela. Barcelona: Ariel, 1985.

Bueno, Salvador. (Selección, prólogo y cronología) Martí por Martí. La Habana: Letras cubanas, 1982.

Caballé, Anna, ed. La pluma como espada. Del Romanticismo al Modernismo. Barcelona: Lumen, 2004.

Cabeza de Vaca, Álvar Núñez. Naufragios. www.elaleph.com. 2000.

Cantavella, Juan. "Epistolarios de escritores: escritura y persona". Cuadernos Hispanoamericanos 463 (1989): 127-137.

Casal, Julián del. Poesía completa y prosa selecta. Ed. Álvaro Salvador. Madrid: Verbum, 2001.

Castillo, Darcie Doll. "La carta privada como práctica discursiva: Algunos rasgos característicos". Signos Vol. 35, No. 51-52 (2002): 33-57.

Castro, Rosalía de. "Carta a Manuel Murguía”. [s.f.]. Caballé 491. 
Catalá Víctor. "Carta a Joan Maragall. 19 de febrero de 1903”. Caballé 213-218.

Cepeda de, José María. "Dejad en paz a los muertos".http://laperegrinamagazine.org/ Jose Maria de Cepeda Gertrudis.html.

--- "Gertrudis Gómez de Avellaneda o los subterfugios del amor". http://laperegrina magazine.org/ Jose Maria de Cepeda Gertrudis Subterfugios.html.

Cervantes, Miguel de. Don Quijote de La Mancha. Madrid: EDIMAT Libros, 2004.

Chaucer, Geoffrey. Los cuentos de Canterbury. Madrid: EDIMAT Libros, 2006.

Cherewatuk, Karen, and Ulrike Wiethaus, eds. Dear Sister-Medieval Women and the Epistolary Genry. Philadelphia: U of Pennylsvania P, 1993.

Cixous, Hélène. La risa de la medusa. Ensayos sobre la escritura. Prof. Ana María Moix. Barcelona: Antropos, 2001.

Colón, Cristóbal. “Carta al Papa Alejandro VI”. Feb. 1502. Ed. Consuelo Varela. Alianza. Quinto Centenario

Coronado, Carolina. "Carta a Juan Eugenio de Hartzenbusch". 24 de octubre [1840] Caballé 454-456.

Cortázar, Julio. "Cartas de mama". El cuento hispanoamericano. Ed. Seymour Menton. 7ma. ed. México: Fondo de Cultura Económica, 2003.

--- $\quad$ Historias de cronopios y de famas. Madrid: Santillana, 2007.

Cortijo Ocaña, Adelaida y Antonio Cortijo Ocaña. "Las cartas de amores: ¿otro género perdido de la literatura hispánica?". Dicenda: Cuadernos de filología hispánica 16 (1998): 63-82

Cotoner, Luisa y Carmen Riera. "Zayas o la ficción al servicio de la educación femenina". Zavala, IV. (De la Edad Media al s. XVIII) 281-303.

Couzens Hoy, David. Foucault. A Critical Reader. Oxford: Basil Blackwell Ltd., 1986.

Craveri, Benedetta. Madame du Deffand and Her World. Boston: David R. Godine, 1994.

De Beauvoir, Simone. The Second Sex. New York: Vintage Books, 1989.

De Laclos, Choderlos. Dangerous Liaisons. Trans. Helen Constantine. London: Penguin Group, 2007. 
Díaz-Diocaretz, Myriam. "«La palabra no olvida de dónde vino». Para una poética dialógica de la diferencia". Breve historia feminista de la literatura española (en lengua castellana) I. Teoría feminista:Discursos y diferencia. Barcelona: Anthropos, 1993.

Don Juan Manuel. El Conde Lucanor. Madrid: Santillana, 1998.

Dreyfus, Hubert L. y Paul Rabinow. Michel Foucault: Beyond structuralism and Hermeneutics. Chicago: Chicago U, 1983.

Durant, Will. The Story of Philosophy. New York: WSP, 1961.

Eco, Humberto. Art and Beauty in the Middle Ages. New Haven: Yale UP, 2002.

--- $\quad$ Historia de la belleza. $7^{\mathrm{a}}$ ed. Milán: Lumen, 2006.

Entralgo, Elías, ed. De la vida íntima. Cartas a Luz Caballero. La Habana: Universidad de La Habana, 1949.

Erasmo de Rótterdam: Epistolas. Publicación: Alicante: Biblioteca Virtual Miguel de Cervantes; Madrid: Fundación José Antonio de Castro, 2006. Edición original en la Biblioteca de la Universidad de Alicante. Edición digital a partir de: Valdés, Juan de, Obras Completas, edición y prólogo de Ángel Alcalá, Madrid, Fundación José Antonio de Castro, 1997, Vol. 1, pp. 1013-1016.

Escaja, Tina. Comp. Delmira Agustini y el Modernismo: nuevas propuestas del género. Rosario: Beatriz Viterbo Editora, 2000.

Escobar Arronis, José. "Narración, descripción y mimesis en el «Cuadro de costumbres»: Gertrudis Gómez de Avellaneda y Ramón Mesonero Romanos". Biblioteca Virtual Miguel de Cervantes. Glendon Collage, Cork University, Toronto.

Esteban, Ángel, ed. Historia de la Monja Alférez, Catalina de Erauso, escrita por ella misma. $2^{\text {nd }}$ ed. Madrid: Cátedra, 2006.

Evans, Ruth, ed. Simone de Beauvoir's The Second Sex. New interdisciplinary essay. Manchester: Manchester U, 1998.

Finucci, Valeria. Ed. and Introduction. Floridoro. A Chivalric Romance. By Moderata Fonte. Chicago: U of Chicago Press, 2006.

Foucault, Michel. A Critial Reader. Ed. David Couzens Hoy. Oxford: Basil Blackwell, 1989. 
--- El sujeto y el poder". Post-scriptum. Michel Foucault: más allá del estructuralismo y la hermenéutica. Hubert L. Dreyfus y Paul Rainbow. Buenos Aires: Nueva Visión, 2001.

--- "What is An Autor?" http://www.openpdf.com/ebook/what-is-an-authorpdf.html.

Franco, Verónica. Poems and Selected Letters. Ed. y Trans. Ann Rosalind Jones and Margaret F. Rosenthal. Chicago: U of Chicago, 1998.

Freud, Sigmund. Epistolario I. (1873-1890). Barcelona: Plaza \& Janes: 1976.

--- $\quad$ Epistolario II. 1891-1939). Barcelona: Plaza \& Janes: 1976.

--- $\quad$ Fear-less Speech. Ed. Joseph Pearson. California: Semiotext(e), 2001.

Gallo, Andrea. "Condesa de Merlín, Viaje a La Habana". Revista Internacional de Cultura y Literaturas. http://www.escritorasyescrituras.com/revista. php/5/50.html.

Gilbert, Sandra M., and Susan Gubar. The Madwoman in the Attic. The Woman Writer and the Nineteench-Century Literary Imagination. $2^{\text {nd }}$ ed. New Haven: Yale UP, 2000.

Goic, Cedomil. Historia y crítica de la literatura hispanoamericana. Del Romanticismo Al Modernismo. Barcelona, Editorial Crítica: 1990.

Gómez, María Asunción. “El problemático ‘feminismo' de La Monja Alférez de Domingo Miras". http://www.ucm.es/info/especulo/numero41/monjalfe.html.

Gómez de Avellaneda, Gertrudis. Autobiografía y epistolarios de amor. Ed. y Prol. Alexander Roselló Selimov. Delaware: U de Delaware, 1999.

--- $\quad$ Dos mujeres. La Habana: Letras Cubanas, 2000.

--- "El viajero americano". Obras literarias de la señora doña Gertrudis Gómez de Avellaneda y Arteaga. Madrid: M. Rivadeneyra, 1869. Google eBook. Vol. I, pp 213-214.

González, Sandra. "Carlos Pío Uhrbach, poeta y mambí". Cuba. Una identità in movimento. Archivo cubano. http://www.archivocubano.orgluhrbach.html.

Gordon, Mary. Virginia Woolf. A Room of One's Own. New York: Harcourt Brace, 1989. 
Graffigny, Françoise de. Lettres d'une Péruvienne. New York: The Modern Language Association of America, 1993.

Grassi, Marie-Claire. Lire l'épistolaire. París: Dunod, 1998.

Grice, Paul. Studies in the Way of Words. Cambridge: Harvard UP, 1989.

Gross, Jonathan David. Ed. and Introd. Byron's "Corbeau Blanc". The Life and Letters of Lady Melbourne. First Texas A \& M UP, 1998.

---, ed. Jonathan David Gross. The Sylph. Georgiana, Duchess of Devonshire. Evanston: Northwestern UP, 2007.

Guarner, José Luis. (recopilador). Antología de la literatura fantástica española. Barcelona: Brugera, 1969.

Guevara, Antonio de. Libro primero de las epistolas familiares. Biblioteca Virtual Miguel de Cervantes. Edición digital basada en la ed. Madrid Aldus. 19501952.

Guillén, Claudio. "El pacto epistolar: las cartas como ficciones". Revista de Occidente. 197 Oct. 1997: 76-98.

--- "On The Edge of Literariness: The Writing of Letters". Comparative Literature Studies 31 (1994): 1-24.

Henríquez Ureña, Max. Panorama histórico de la literatura cubana. México: Mirador, 1963.

Herpoel, Sonja. "Un mar de misterios: la religiosa española ante la escritura". Zavala, Iris M. IV. La literatura escrita por mujer 205-223.

Hospital, Carolina y Jorge Cantera. Ed. A Century of Cuban Writers in Florida. Florida: Pineapple, 1996.

Iañez, Eduardo. Historia de la literatura. El siglo XIX. Literatura Romántica Barcelona: Bosh, 1991.

Infante Don Juan Manuel. El Conde Lucanor. Madrid: Santillana, 1998.

Jensen, Katharine Ann. Writing Love. Letters, Women, and the Novel in France, 16051776. Carbondale: Southern Illinois UP, 1995.

Jiménez Faro, Luzmaría. Delmira Agustini, manantial de la brasa. Madrid: Torremozas, 1991. 
Jiménez, José Olivio y Carlos Javier Morales. La prosa modernista hispanoamericana. Madrid: Alianza, 1998.

Jones, Ann Rosalind and Margaret F. Rosenthal. Ed. Verónica Franco. Poems and Selected Letters. Chicago: Chicago UP, 1998.

Jordan, Barry. "Narrators, readers and writer in Laforet Nada". Notthingham U. http//www.jstor.org/stable/30205864.

Kafka, Franz. Carta al padre y otros escritos. Carmen Gauger (trad.). Madrid: Alianza, 2002.

Kayser, Wolfgang. Interpretación y análisis de la obra literaria. 4ta. ed. Madrid: Gredos, 1961.

Kelly, Catriona. A History of Russian Women's Writing. 1820-1992. Oxford: Oxford UP, 1994.

Keymer, Thomas. Ed. Pamela; or, Virtue Rewarded. By Samuel Richardson. Oxford: Oxford UP, 2001.

Kirkpatrick, Susan. Las Románticas: Escritoras y subjetividad en España, 1835-1850. Madrid: Cátedra, 1991.

--- $\quad$ Mujer, modernismo y vanguardia en España. (1898-1931). Madrid: Cátedra, 2003.

Kristeva, Julia. Desire in Language. A semiotic Approach to Literature and Art. Ed. Leon S. Roudiez. New York: Columbia UP, 1980.

--- $\quad$ Language the Unknown. An initiation into Linguistics. Anne M. Menke (traductor). New York: Columbia U, 1989.

Lacan, Jacques. The Tour Fundamental Concepts of Psycho-Analysis. Ed. Jacques-Alain Millar. New York: W.W. Norton \& Co., 1973.

--- $\quad$ The Language of the Self. The Function of Language in Psychoanalysis. Anthony Wilden (trans.). Baltimore: The Johns Hopkins Press, 1968.

Lafayette (Marie-Madeleine Pioche de la Vergne, Madame de Lafayette). The Princesse de Clèves. London: Penguin, 2004.

Lagmanovich, David. "La extrema brevedad: microrrelatos de una y dos líneas". Espéculo. Revista de estudios literarios. U Complutense de Madrid. http://www.ucm.es/info/especulo/numero32/exbreve.html. 
Lazo, Raimundo. La literatura cubana. México: Universidad Nacional Autónoma de México, 1965.

Lezama Lima, Eloísa. Ed. Cartas 1939-1976. Madrid: Orígenes, 1979.

Loureiro de Renfrew, Ileana. La imaginación en la obra de Delmira Agustini. Montevideo: Letras Femeninas, 1987.

Machado Bonet de Benvenuto, Ofelia. Delmira Agustini. Montevideo: Ceibo, 1944.

Maquiavelo, Nicolás. Epistolario 1512-1527. Stella Mastrangelo. (trad.). México: Fondo De Cultura Económica: 1990.

Mallison, Jonathan. (Introduction). Letters of a Peruvian Woman. By Françoise de Graffigny. New York: Oxford UP, 2009.

Marchese, Angelo y Joaquín Forradellas. Diccionario de retórica, crítica y terminología literaria. 3. ${ }^{\text {a }}$ ed. Barcelona: Ariel, 1991.

Marín Abeytua, Diego. "El correo electrónico como nuevo género epistolar en la literatura actual". Universidad de Rioja.

Dialnet.unirioja.es/servlet/articulo?codigo $=940470$.

Marini-Palmieri, Enrique. Cuentos modernistas hispanoamericanos. Madrid: Castalia, 1989.

Martí, José. Epistolario. 1889-1893. Barcelona: Athena Books, 2004.

--- Ismaelillo. La Edad de Oro. Versos sencillos. México: Porrúa, 2000.

--- Lucía Jerez. Madrid: Cátedra, 1994.

Martín Baños, Pedro. "Retórica epistolar: de la carta a la autobiografía, el ensayo y la novela. Actas de las III Jornadas de Humanidades Clásicas. Almendralejo. Febrero de 2001: 147-154.

Menton, Seymour. El cuento hispanoamericano. 7ma ed. México. Fondo de Cultura Económica: 2003.

Miguel de, Armando. La España de nuestros abuelos. Historia íntima de una época. Madrid. Espasa: 1998.

Moi, Toril. Teoría literaria feminista. $4^{\mathrm{a}}$ ed. Madrid: Cátedra, 2006. 
Moris Campos, Judith y Manuel Aznar Soler. "Hacia una desarticulación del tópico de la 'virgen triste' en el Epistolario de Juana Borrero". Universitat Autònoma de Barcelona. Facultad de Filosofia i Lletres. www/recercart.net/bitstream/2072/4361.

Moix, Ana María. Prólogo. La risa de la medusa. Por Hélene Cixous. Barcelona: Anthropos, 1995.

Montaigne, Michael de. Essays. Trans. J.M. Cohen. London: Penguin, 1993.

Morales, Carlos Javier, ed. Lucía Jerez. By José Martí. Madrid: Cátedra, 1994.

Morales Ladrón, Marisol. "La dialéctica entre la presencia y la ausencia ficcional Del destinatario en el discurso epistolar". Anuario de la Sociedad Española de Literatura General y Comparada. 10 (1996), pp. 285-295.

Morales T., Leonidas. Carta de amor y sujeto femenino en Chile. Siglo XIX y XX. Santiago: Cuarto Propio, 2003.

Morán, Francisco. ed. La pasión del obstáculo. Poemas y cartas de Juana Borrero. Buenos Aires: Stock Cero, 2005.

--- Julián del Casal o lo pliegues del deseo. Nueva Orleáns: Verbum, 2008.

Morcillo Espósito, Guadalupe. "Pedro Martín Barrios, El arte epistolar en el Renacimiento Europeo 1400-1600”. Talia Dixit. 2006: 113-120.

Moris Campos, Judith. "Hacia una desarticulación del tópico de la 'virgen triste' en el Epistolario de Juana Borrero". Diss. Universitat Autònoma de Barcelona, 2007. http://hdl.handle.net/2072/4361.

Mossiker, Frances. Madame de Sévigné. A Life and Letters. New York: Columbia UP, 1985.

Muñoz Martín, Nieves. Teoría epistolar y concepción de la carta en Roma. Granada: Universidad de Granada, 1985.

Otte, Enrique. Cartas privadas de emigrantes a Indias. 1540-1616. México: Fondo de Cultura, 1993.

Pagés-Rangel, Roxana. Del dominio público: itinerarios de la carta privada. Ámsterdam: Rodopi, 1997.

Parra, Teresa de la. Ifigenia. Tomo II. 3ra ed. Caracas: Monte Avila, 1990. 
--- Epistolario Íntimo. Caracas: Línea Aeropostal Venezolana, 1953.

Pastor, Brígida. El discurso de Gertrudis Gómez de Avellaneda: identidad femenina y otredad. Murcia: Cuadernos de América sin nombre, 2002.

Pérez-Abreu, Catalina. "La mujer como enfermedad y muerte en el proyecto modernista: Notas para un estudio". Espectáculo. Revista de estudios literarios. U Complutense de Madrid. http://www.ucm.es/info/especulo/numero30/mujermod.htm.

Pérez Alvarez, Jorge A. Psicología de la comunicación y relaciones interpersonales. U de San Martín de Porres.http://www.scribd.com/doc/20928796/.

Pérez Murillo, María Dolores. Cartas de emigrantes escritas desde Cuba: estudios de las mentalidades y valores en el siglo XIX. Cádiz: Aconcagua Libros, 1999.

Pessoa, Fernando. Sobre literatura y arte. Madrid: Alianza, 1985.

--- "Pasión, imaginación, pensamiento". http://ensayopessoa.blogspot.com/2007/10/pasin-imaginacinpensamiento.html.

Peyre, Henri. Literatura and Sincerity. New Haven: Yale University, 1963.

Phillips-López, Dolores. Cuentos fantásticos modernistas de Hispanoamérica. Madrid. Cátedra: 2003.

Picon Garfield, Evelyn. Poder y sexualidad: el discurso de Gertrudis Gómez de Avellaneda. Atlanta: Rodopi, 1993.

Pioche de la Vergne, Marie-Madeleine. Madame de Lafayette. The Princiess de Clèves. Trans. Robin Buss. New York: Penguin, 2004.

Poe, Edgar Allan. Great Tales and Poems of Edgar Allan Poe. New York: Washington Square Press, 1951.

Poniatowska, Elena. Querido Diego, te abraza Quiela. Vigésima reimpresión. México: 2002.

Prado, María. "La vida vislumbrada". La pluma como espada: Del Romanticismo al Modernismo. Ed. Anna Caballé. Barcelona: Lumen, 2004. 14-40.

Pulido Tirado, Genara. "La escritura epistolar en la actual encrucijada genérica". Centro de documentación epistolar. http://www.cartas.org.ar/lecturas/lec-pul-lae.html.

Quintero Editores. Las más bellas cartas de amor. Bogota: La Oveja Negra, 2007. 
Remos, Juan J. Proceso histórico de las letras cubanas. Miami: Editorial Cubana, 2003.

Reyes, Alfonso. Prosa y poesía. 3ra ed. Madrid: Cátedra, 1984.

Rico, Francisco, La novela picaresca y el punto de vista. Barcelona: Seix Barral, 1970.

Rilke, Rainer María. Cartas a un joven poeta. 6ta ed. José María Valverde (trad.). Madrid: Alianza, 2006.

Rojas, Fernando de. La Celestina. Barcelona: Actual, 1997.

Rodríguez-Arenas, Flor María. "La carta ficticia como género narrativo en el temprano periodismo decimonónico colombiano". Signos Literarios y Linguísticos. III.I (enero-junio, 2001), 87-106.

Rodríguez, Francisco. "El género autobiográfico y la construcción del sujeto autorreferencial." Filología y Lingüistica XXVI(2):9-24, 2000.

Romanos, Mesonero. "El romanticismo y los románticos". Escenas matritenses http://es.wikisource.org.

Romero, Cira. Ed. Compañeros de viaje. Correspondencia de Alfonso HernándezCatá con intelectuales cubanos (1908-1940). Santiago de Cuba: Oriente, 2004.

Romeo, Raquel. Voces de mujeres en la literatura cubana. Madrid: Verbum, 2000.

Rossi, Rosa. "Instrumentos y códigos, la «mujer» y la «diferencia sexual»". Breve historia feminista de la literatura española (en lengua castellana). I. Teoría feminista: discursos y diferencia. Barcelona: Antropos, 1993.

Ruiloba, Rafael. Sor Juana Inés de la Cruz o la batalla entre el saber y el poder. Panamá: Portobelo, 1999.

Ruiz, Juan, Arcipreste de Hita. Libro de Buen Amor. Ed. Nicasio Salvador Miguel. México: Origen, 1984.

Salinas, Pedro. El defensor. Madrid: Alianza, 2002.

San Pedro, Diego de. Cárcel de amor. Madrid: Cátedra, 1999.

Sand, George. Indiana. Trans. Sylvia Raphael. New York: Oxford U, 2000.

Santidrián, Pedro R. Introducción y Trad. Cartas de Abelardo y Eloísa. Madrid: Alianza, 2007. 
Schulman, Iván. El proyecto inconcluso. México: Siglo Veintiuno, 2002.

--- Símbolo y color en la obra de José Martí. Madrid: Gredos, 1960.

Sebold, Russell P. Pórtico. Gertrudis Gómez de Avellaneda. Autobriografía y Epistolarios de amor. Delaware: U of Delaware, 1999.

Selimov, Alexander Roselló. «Introducción». Gertrudis Gómez de Avellaneda: Autobiografia y Epistolarios de amor. Delaware: U of Delaware, 1999.

Servén Díez, Carmen. Ed. La mujer en los textos literarios. Madrid: Akal, 2007.

Shelley, Mary. Frankenstein. New York: Barnes \& Noble, 2004.

Showalter, Elaine. Ed. Feminist Criticism: Essays on Women, Literature Theory New York: Pantheon Books, 1985.

--- $\quad$ The Female Malady: Women, Madness and English Culture, 1830-1980. New York: Pantheon Books, 1985.

Silva, Clara. Genio y figura de Delmira Agustini. Buenos Aires: Universidad de Buenos Aires, 1968.

--- $\quad$ Pasión y gloria de Delmira Agustini. Buenos Aires: Losada, 1972.

Sommer, Doris. Foundational Fictions. The Nacional Romances of Latin America. Berkeley: U of California, 1991.

Soto Vergara, Guillermo. "La creación del contexto: function y estructura en el género epistolar". ONOMÁZEIN 1 (1996), 152-166.

Stephens, Doris T. Delmira Agustini and the Quest for Transcendence. Montevideo: Gemenis, 1975.

Torres-Pou, Joan. "La Avellaneda y Dos mujeres: un insólito alegato femenino en la literatura decimonónica". Ojáncanos. (Oct. 2002), 21-32.

Valenzuela, Luisa. "Diez breves puntos sobre el microrrelato" http://porlamatria.blogspot.com/2010/01/diez-breves-puntos-sobre-el.html En: Al Sur de la Palabra. IV Encuentro de escritores por el fomento del libro y la lectura. Corporación Letras de Chile. Santiago: Mosquito Comunicaciones, 2005.

Varas, Patricia. Las máscaras de Delmira Agustini. Montevideo: Vintén, 2000.

Varela y Morales, Félix. Cartas a Elpidio. Tomo I, II. La Habana: Biblioteca de Autores Cubanos. Ed. de la Universidad de La Habana, 1945. 
Vela Delfa, Cristina. El correo electrónico: el nacimiento de un nuevo género. Diss. Madrid: U Complutense, 2006.

Vega de la, Gracilazo. Poesía castellana completa. Madrid: Cátedra, 1980.

Verlaine, Paul. Los poetas malditos. Bogotá: Panamericana, 1999.

Vitier, Cintio. Juana Borrero. Epistlario. (Prólogo). La Habana: Biblioteca de autores cubanos. Academia de Ciencias de Cuba, 1966.

--- Lo cubano en la poesía. La Habana: Letras Cubanas, 2002.

--- Temas martianos. La Habana: Huracán, 1969.

Vitier, Medardo. Las ideas y la filosofia en Cuba. La Habana: Editorial de Ciencias Sociales. Instituto del Libro, 1970.

Waid, Candace. Edith Wharton's Letters from the Underworld. North Carolina: U of North Carolina P, 1991.

Wharton, Edith. The Age of Innocence. New York: Barnes \& Noble Classics, 2004.

Wellek, René y Austin Warren. Teoría literaria. 4ta ed. Madrid: Gredos, 1966.

Woolf, Virginia. A Room of One's Own. Mary Gordon (Foreword). New York: Harcourt Brace, 1989.

Zamudio, Adela. "Carta abierta a R.P. Fray Francisco Pierini. 26 de diciembre de 1913. Caballé, 323-329.

Zavala, Iris M. Breve historia feminista de la literatura española (en lengua castellana). I.Teoría feminista: discursos y diferencia. (Coords.) Myriam Díaz-Diocaretz e Iris M. Zavala. Barcelona: Anthropos, 1993.

--- $\quad$ (Coord.) Breve historia feminista de la literatura española (en lengua castellana). III. La mujer en la literatura española (Del s. XVIII a la actualidad). Barcelona: Anthropos, 1996.

--- $\quad$ (Coord.) Breve historia feminista de la literatura española (en lengua castellana. IV. La literatura escrita por mujer (De la Edad Media al s. XVIII). Barcelona: Anthropos, 1997.

Zayas, María de. Tres novelas amorosas y tres desengaños amorosos. Ed. Alicia Redondo Goicoechea. Madrid: Castalia, 1989. 
VITA

COINTA G. MARTIN

Certified Elementary Teacher K-6

Certified Spanish Teacher K-12

ESOL Endorsement

\section{Work Experience in Education}

2006-Present Maya Angelou Elementary, Teacher. EFL Program.

2002-Present Miami Dade College

Professor- English for Academic Purposes

2004-2008 Florida International University

Professor- Spanish as Second Language

2

2005-2008 Berlitz Language Institute. Professor, English and Spanish

\section{Work Experience}

1988-2003 Allen, Norton \& Blue, P. A.

Accounts Receivable - Accounting Programs-Reports- Translations.

1983-1988 State of Florida, Department of Business Regulations

Secretary to the Bureau Chief

\section{Education}

4/2008 Florida International University

Ph.D., Art in Spanish PhD. (Dissertation Pending).

3/2005 Florida International University

Master of Art in Spanish

4/2002 Florida International University

Master of Science in Modern Language Education

12/2001 Florida International University

Bachelor of Arts in Spanish

1999 Miami Dade Community College. Associate in Arts in Finance.

Translation and Interpretation Certification.

\section{Honors and Awards}

$6 / 2009$

$4 / 2001$

$12 / 2001$

2008
Service Excellence, ESL/FL, MDC.

Award for Outstanding Academic Achievement in Spanish, F.I.U.

Magna Cum Lauden, Bachelor of Arts in Spanish, F.I.U.

Special Guest, WQBA Radio Station, on the epistolaries of

Gertrudis Gómez de Avellaneda, Juana Borrero and Delmira Agustini

$(4 / 16 ; 5 / 14 ; 11 / 11 ; 7 / 30 \& 7 / 31 / 09)$. 